
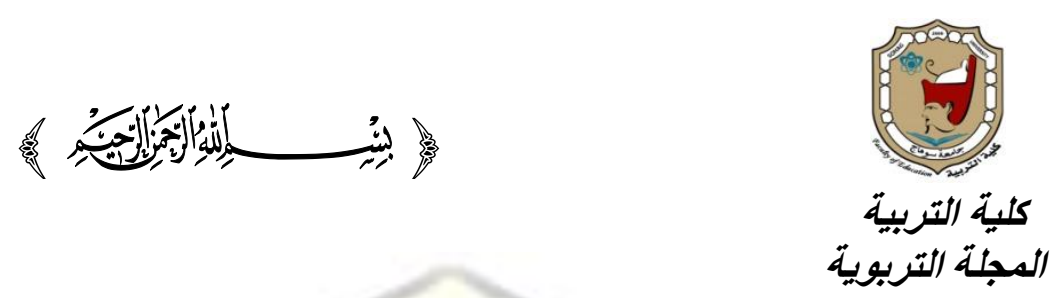

تعرض طلاب الثانوية العاهة لأخبار انتمار الطلاب علي هواقع التواصل الاجتهماكي وعلاقته بمستوى قلق

$$
\text { الامتمتحان لديهميم }
$$

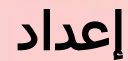

د/ أحمــد عبد الكافي عبد الفتاح

أستاذ الصحافة المساعد بقسم الإعلام التربوي

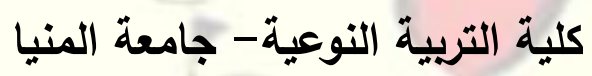

DOI: 10.12816/EDUSOHAG. 2020.

المجلة التربوية ـ العدد السادس والسبعون - أغسطس •r.r. Print:(ISSN 1687-2649) Online:(ISSN 2536-9091) 
تعلخص طلاب الثانوية العامة لأخبار انتحار الطلاب علي مواقع التواصل الاجتماعي

تعرض طلاب الثانوية العامة لأخبار انتحار الطلاب علي مواقع التواصل الاجتماعي

وعلاقته بمستوي قلق الامتـحان لايهم

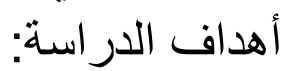

تهذف هذه الدراسة إلي التعرف علي درجة متابعة طلاب الثانوية العامة لأخبار انتحار الطلاب علي مواقع التواصل الاجتماعي ، وقياس مستوي قلق الامتحان لعينة الدراسة بالنسبة لوزه القضية.

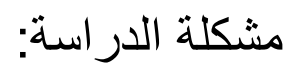

تتلخص مشكلة الدراسة في محاولة التعرف علي العلاقة بين تعرض طلاب الثانوية العامة لأخبار انتحار الطلاب علي مواقع التواصل الاجتماعي وقلق الامتحان. نوع ومنهج الدراسة:

تنتمي هذه الدراسة إلى الدراسات الوصفية ، وتعتمد على منهج المستح بالعينة . العينة: طبق الباحث دراسته علي عينة عشوائية متاحة قوامها ( . . ـ طالب وطالبة من طلاب الثانوية العامة بمحافظة المنيا (مدارس الريف - مدارس الحضر)

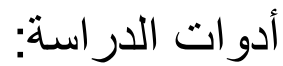
1 - و صحيفة الاستبيان. r - مقياس قلق الامتحان لسارسون

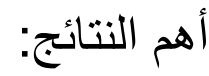
1 - تصدر موقع (يوتيوب) مواقع التواصل الاجتماعي التي يحرص المبحوثون على متابعة أخبار انتحار الطلاب فيما حل موقع( توتير) في الترتيب الأخير. r - عدم وجود فروق ذات دلالة إحصائية بين عينة الدراسة حسب (النوع (ذكور - إناث) محل الإقامة (حضر - ريف) في معدل التعرض لأخبار انتحار الطلاب علي مواقع التواصل الاجتماعي. 
تعرض طلاب الثانوية العامة لأخبار انتحار الطلاب علي مواقع التواصل الاجتماعي ..

Summary of the study

Exposure of general high school students for news of students suicide on social media websites and it's relation with the level of their examination anxiety

\section{Goal of the study :}

This study aims at recognizing the extent of general high school students follow up for the news of students suicide on social media websites and measuring the level of examination anxiety for the study sample of this issue .

Problem of the study :

The problem of the study is summarized in the attempt to recognize the relationship between the exposure of general high school students for the news of students suicide on social media websites and examination anxiety .

Type and method of the study :

This study belongs to the descriptive ones and depends method upon sampling survey .

The sample :

The researcher applied his study on an available random sample of ( 400) male and female students from general high school students at Minia governorate ( rural -urban schools ).

Tools of the study :

1-The questionnaire .

2- Sarason examination anxiety scale .

The most important results :

1- The site ( YouTube ) leads social media websites in which the respondents are keen to follow for news of students suicide, whereas the site ( Twitter) came in the final order .

2- There are no statistically significant differences between the study sample according to the gender ( males - females ) - residence place ( urban rural) in the ratio of exposure for students suicide news on social media websites . 
تعد قضية الانتحار قضية أزلية وليست جديدة وتعاني منها كل البلدان علي مستوي العالم ومنذ سنوات طويلة والبحث العلمي منشغل بها بصفة مستمرة لمعرفة أسبابها وتداعياتها، وتظهر العديد من الدراسات العلمية ويصفة خاصة في علم النفس تطور وتتامي

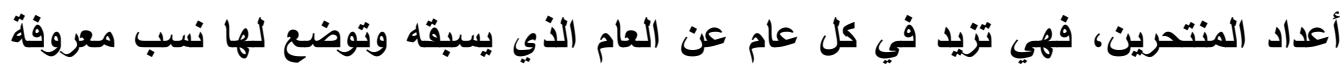

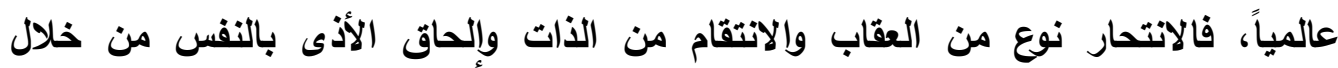

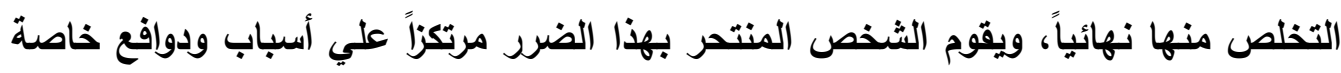
به ويقتاعته الشخصية، والاكتئاب الشديد الذي يتعرض له قد يؤدى إلى تطور فكرة الانتحار لاى الشخص والتي غالبا ما تترجم إلي ممارسة عملية. ليست مصريمنأى عن هذه المشكلة حيث تتثثر أخبار الانتحار بين فئة طلاب

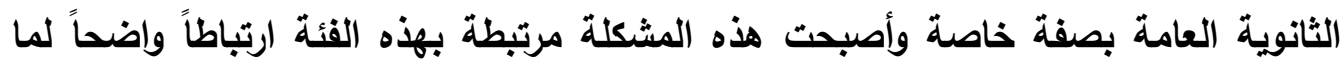

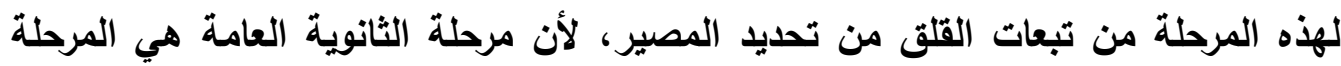

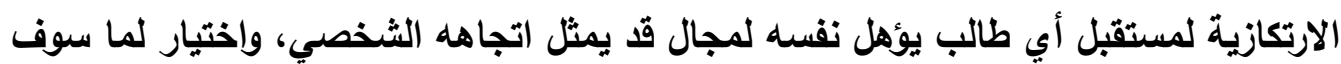
يقوم بالاستمرار فيه أو قد يكون محاولة لإرضاء ولي أمره. وتقوم معظم وسائل التواصل الاجتماعي علي شبكة الانترنت (بصفة خاصة) بعرض الإصل

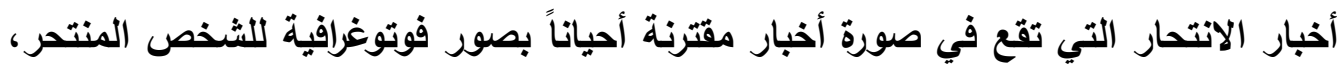
أو قد تقوم بعرض فيديو يشرح كافة التفاصيل والأسباب والملابسات التي تحيط بهذه الجريمة لو جاز عنها التعبير بهذا المصطلح، ومن هذا المنطلق يظهز التأثير الأي يفترضه الباحث نحو هذه الدراسة، والذي يتمثل في قلق الامتحان الذي يشعر به الطلاب قبل وأثناء

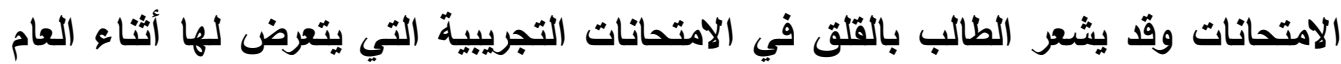
الاراسي وليس في امتحان آخر العام فقط، ومن هذه النقطة كانت هذه الدراسة محاولة للتعرف علي العلاقة بين تعرض طلاب الثانوية العامة لأخبار الانتحار علي مواقع التواصل الاجتماعي وقلث الامتحان. 
تعرض طلاب الثانوية العامة لأخبار انتحار الطلاب علي مواقع التواصل الاجتماعي الإطلار النظري للار اسـة:

القلق ظاهرة قديمة حديثة صاحبت الإنسان منذ مولده الأول، بيد أن هذا العصر لإنر

الذي نعيشه بما صاحبه من تغيرات متلاحقة، وضغوط، جعل الإنسان يشعر بأن القلق يلازمه هوله في كل جانب من جوانب حياته، غير أن جانباً من هذا القلق يمكن أن يكون خلاقا إيجابيا

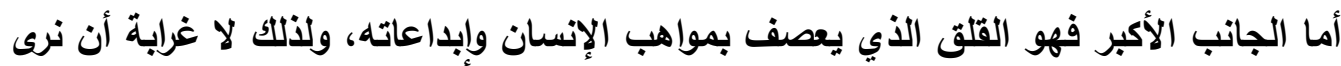
إجماعا لاى معظم علماء النفس أن القلق هو المحور والمحرك الأساسي لجميع الأمراض

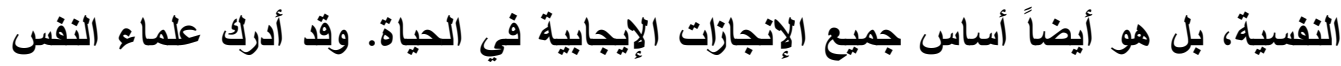
منذ الخمسينيات أهمية دراسة العلاقة بين القلق والتعلم، وإلكثير من نتائج الدراسات كثفت الإبات

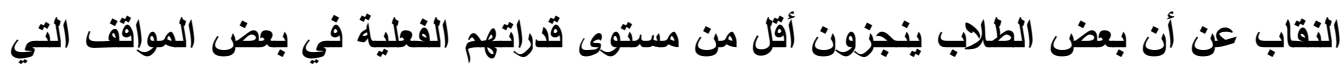

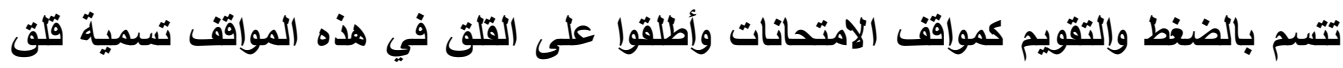

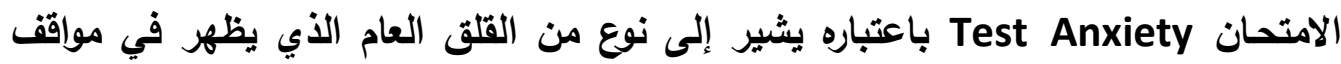

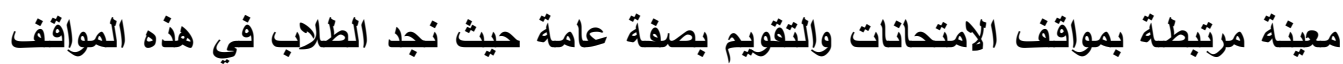

يشعرون بالاضطراب والتوتر والضيق (').

وتؤدي الامتحانات دورا مهما في حياة الطلاب وهي أحد أساليب التقييم الضرورية إلا

أنها قد ترتبط بها ما يجعل منها مشكلة مخيفة ومقلقة. ويتخذ قلق الامتحان أهمية خاصة، نظرا لارتباطه الثديد بتحديد مصير الطالب ومستقبله الدراسي والعملي، ومكانته في المجتمع، ولذلك فهو يعتبر دراسة حقيقية لكثير من الطلاب وأسرهم أيضا، بل ويالنسبة

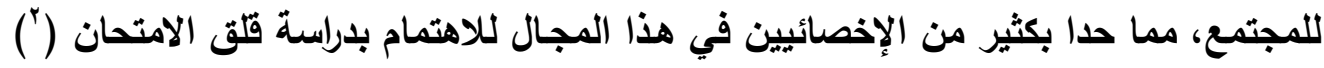
وذكرت منظمة الصحة العالمية في عام 9 . . . لمنطقة جنوب شرق آسيا أن معدل

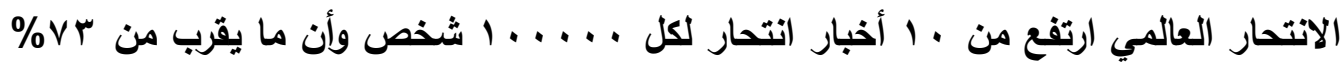

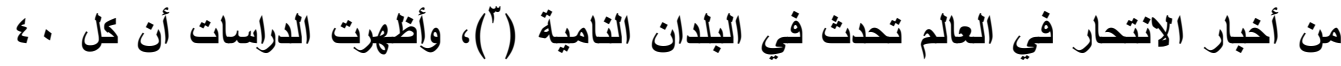
ثانية هناك شخص ما في العالم يفكر في الانتحار هذا هو الرقم الأي أعلنته منظمة الصحة

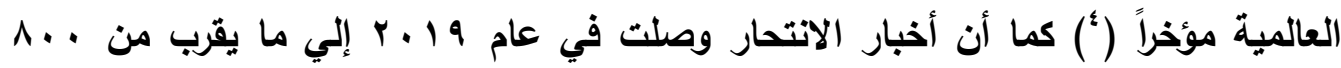
ألف شخص علي مستوي العالم مات بالانتحار، وهذا ضعف أخبار جرائم القتل، فضلا عن أن الن النان الانتحار هو أحد الأسباب الرئيسية في وفاة الشباب ( ). 
تعددت التعريفات التي تناولت موضوع قلث الامتحان، وقد عرفه كثير من المهتمين والإخصائيين في هذا المجال، ويستعرض الباحث في هذا المقام بعض من تعريفات وآراء هؤلاء الإخصائيين حول قلق الامتحان، وهي كالتالي: هو نوع من القلث المرتبط بمواقف الامتحان، حيث تثير هذه المواقف في الفرد

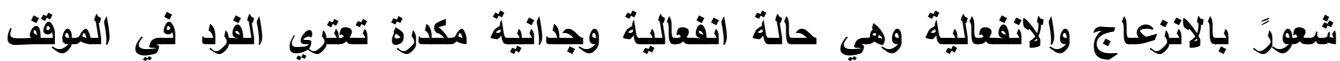
السـابق للامتحان، أو موقف الامتحان ذاته وتتسم هذه الحالة بالشعور بالتوتر والخوف من الامتحان ("). وعرف سبيلبيرجر قلق الامتحان بأنه سمة شخصية في موقف محدد ويتكون من الانزعاج والانفعالية، ويعرف الانزعاج بأنه اهتمام معرفي يتمثل في الخوف من الفشل، الأله بينما الحالة الانفعالية هي ردود أفعال الجهاز العصبي ويمثل هذين المكونين الانزعاج

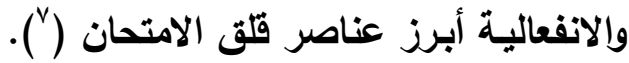

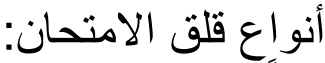

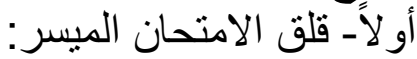
هو القلق المعتدل، ذو التأثير الايجابي المساعد، ويدفع الطالب للاراسة والاستذكار والتحصيل المرتفع، وينشطه ويحفزه علي الاستعداد للامتحانات وييسر أداء الامتحان.

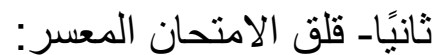
هو القلق المرتفع من الامتحان ، ذو التأثير السلبي المعوق، حيث تتوتر الأعصاب

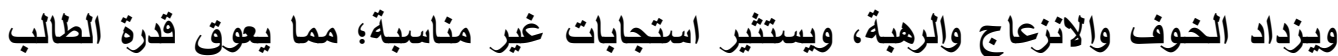
علي التذكر والفهم، ويريكه حين يستعد للامتحان، ويعر أداء الامتحان. ( (^). مكونات قلق الامتحان:

يشير المهتمون في هذا المجال إلي أن قلق الامتحان يتضمن مكونين أساسيين، هما: - المكون المعرفي: أو الانزعاج Worry سيث ينشغل الفرد بالتفكير في تبعات الفشل، مثل: فقدان المكانة والتقدير، وهذا يمثل سمة القلث. - المكون الانفعالي: أو الانفعالية Emotionality، حيث يشعر الفرد بالضيق والتوتر والهـلع من الامتحانات، بالإضافة إلي مصاحبات فسيولوجية، وهذا يمثل حالة القلق("ج). 
وأضاف زهران أن هناك خمسة عوامل خاصة بقلث الاختبار وهي كالتالي:

$$
\text { r. الض الخوف والرهبة من الاختبار. }
$$

r. الخوف من الاختبارات الثفوية المفاجئة.

؛. الصراع النفسي المصاحب للاختبار.

ه. الاضطرابات النفسية والجسمية المصاحبة للاختبار ( (').

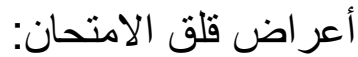

يعتبر قلق الامتحان من نوع قلق الحالة تمييزاً له عن قلق السمة ومن الأعراض التي

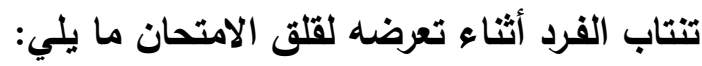
• الأرق والتوتر وفقدان الشهية، وتسلط بعض الأفكار الوسواسية قبيل وأثناء الامتحان. • كثرة التفكير في الامتحانات والانشغال قبل وأثناء الامتحان في النتائج المترتبة عليها. تسارع خفقان القلب وسرعة التفس وتصبب العرق، وألم البطن والغثيان. • الإحساس بالضيق النفسي الثديد قبل وأثناء تأدية الامتحان ('"). • الخوف والرهبة من الامتحان والتوتر قبل الامتحان. الاضطراب الواضح في العمليات العقلية كالانتباه والتركيز والتفكير. • الارتباك والتوتز ونقص الاستقرار والأرق ونقص الثقة بالنفس. تثتت الانتباه وضعف القدرة علي التركيز واستدعاء المعلومات أثناء أداء الامتحان. • الزعر الانفعالي الذي يشعر فيه الطالب بأن عقله صفحة بيضاء، وأنه نسى ما ذاكر بمجرد الاطلاع علي ورقة أسئلة الامتحان. • التداخل المعرفي، يتمثل في أفكار سلبية غير مناسبة عن الامتحانات، ونقص إمكانية

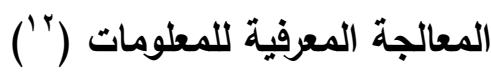

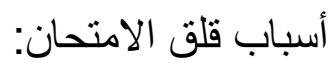

وضع المهتمون في المجال التربوي والصحة النفسية العديد من أسباب قلث الامتحان

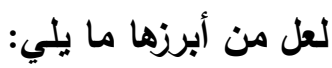
1) مشكلات تعلم المعلومات أو تنظيمها أو مراجعتها قبل الامتحان، أو استدعائها في موقف الامتحان ذاته. r ) عدم وجود الرغبة في النجاح والتقوق. 
r) ضعف المعرفة بالموضوعات الدراسية. ؛) اقتران الامتحان بخبرة الفشل في حياة الطالب، وتكرار مرات الفشل. ه) تلني في الاستعداد للامتحان كما يجب. ؟) نقص الثقة بالنفس والتمركز حول الذات،.

الاتجاهات السلبية لادي الطلاب والمعلمين والوالدين نحو الامتحانات. ^) الشعور بصعوية الامتحانات وأن المستقبل يتوقف علي الامتحانات. 9) الضغوط البيئية، وخاصة الأسرية، لتحقيق مستوي طموح لا يتناسب مع قدرات الطالب. · ) الضغوط المباشرة، حين يتعرض الطالب للتهايد أو يواجه الفشل. المنافسة مع الرفاق ومحاولة إرضاء الوالدين والمعلمين.

r r l ) (كتساب قلق الامتحان حين يقترن بمثيرات منفرة مثل التقييم الاجتماعي السالب.

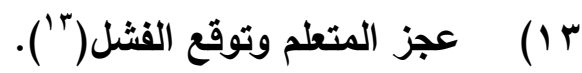
الانتحار:

كل عام يلقى ما يقارب ثماني مائة ألف شخص حتفه كل عام بسبب الانتحار، ومقابل كل حالة انتحار هناك الكثير من الناس الذين يحاولون الاتتحار وتمثل محاولة الانتحار السابقة أهم عامل خطر لعموم السكان، ويعتبر الانتحار ثاني أهم سبب للوفاة بين من تتراوح أعمارهم بين ه او ج ج عاما، وتستأثر البلدان المنخفضة والمتوسطة الاخل بنحو \% من أخبار الانتحار في العالم.

وتؤكد منظمة الصحة العالمية أن الانتحار إحدي القضايا التي تحظى بالأولوية. حيث كان أول تقرير لمنظمة الصحة العالمية حول الانتحار بعنوان "الوقاية من الانتحار:

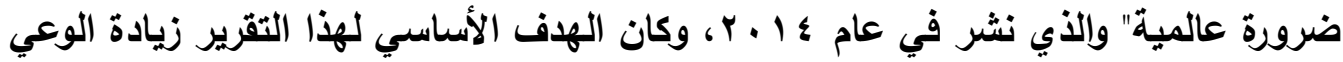
بأهمية الانتحار ومحاولات الإقام عليه ، وجعل الوقاية من الانتحار أولوية قصوى على جدول أعمال الصحة العمومية العالمي؛ كما يهذف التقرير إلى تثجيع البلدان ومساعدتها في تطوير أو تعزيز استراتيجيات شاملة للوقاية من الاتتحار في سياق نهج متعدد القطاعات للصحة العمومية (؛ أ) 

تعريف الانتحار:

أوضحت سوسن شاكر في تعريفها للإنتحار بأنه: هو الفعل أو مجموعة الأفعال التي

قام بها الفرد لقتل نفسه بنفسه؛ وقد تم له ذلك وانتهت حياته نتيجة لتلك الأفعال ( (10).

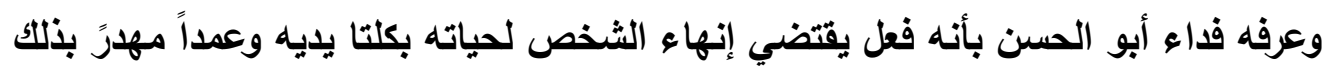
حقه في الحياة، والتي يعتبر أقدس حقوق الإنسان على الإطلاق، ويعد الانتحار جريمةً دافعها الأساسي اليأس والاضطرابات النفسية (17'). ولمنع انتحار المراهقين أوضحها Surachai Chaniang and others في الآتي:

تعزيز احترام الذات ودعم الوالدين ورعايتهم ودعم الأقران والبيئات المدرسية الداعمة (

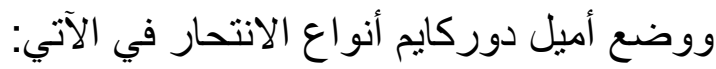
1- الانتحار الأناني: تظهر المعدلات العالية من الانتحار الأناني غالبا في المجتئ الإنمعات التي يكون فيها الفرد غير مندمج تمامًا في الوحدة الاجتماعية الكبرى؛ لأن تفكك المجتمع ينتج الآل تيارات اجتماعية مميزة وهي السبب الأساسي في تباين معدلات الانتحار.

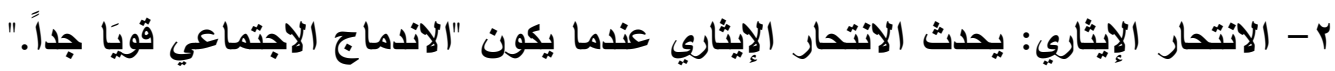
الفرد يجبر حرفيا علي ارتكاب فعل الانتحار r- الاتتحار اللامعياري: يحدث الاتتحار اللامعياري في أغلب الأحيان عندما تضطرب ضوابط الإن

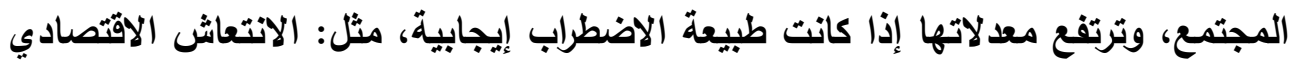
مثلا أو سلبية مثل الكساد الاقتصادي فكلا النوعين من الاضطراب يؤدى إلى التعطيل

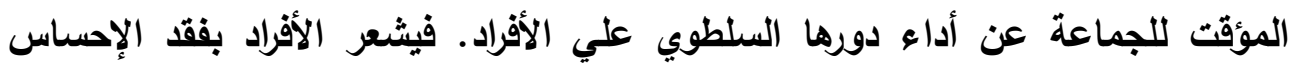
وإنعدام الجذور المعايير. وتقود إلى الزيادة في معدلات الانتحار المعياري. ع - الاتتحار القدري : فيما سبق أوضحنا أن الانتحار اللامعيارى يحدث في في الأخبار التي تضعف فيها الضوابط فان الانتحار القدري يحدث في الأخبار التي تكون فيها الضوابط متجاوزة للد المرغوب فيه. ووصف دوركايم الذين يرتكبون فعل الانتحار القدري بأنهم "أثخاص مستقبلهم مغلق بقسوة ونزواتهم خنقت بعنف عن طريق نظام قهري ( (^). 

خدمات مو اقع التو اصل الاجتماعي:

أثير الحديث عن التحولات والظواهر الاجتماعية وإلنفسية والسياسية والاقتصـادية المختلفـة منـذ أن بـأت مواقع التواصل الاجتمـاعي في بدايـة القرن الواحد والعشرين كنتاج

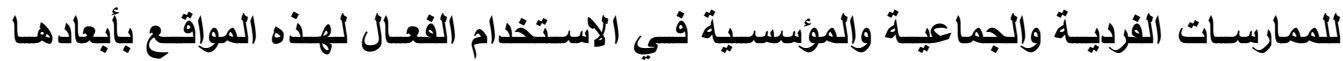
المعلوماتية والمعرفية (19).

وتسهم مواقع التواصل بتقديم خدمات عديدة منها إتاحة المجال للأفراد في الاخول إلي المواقع الاجتماعية والتعريف بأنفسهم، ومن ثم التواصل مع الآخرين الذين تربطهم بهم

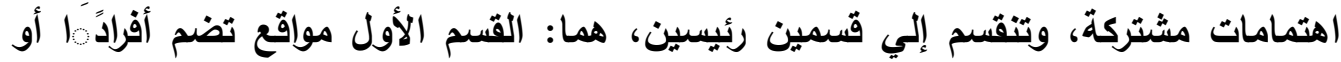
مجاميع من الناس تربطهم إطارات مهنية أو اجتماعية محددة، وتعتبر هذه المواقع مغلقة ولا يسمح بالاخول إليها من عامة الناس إلا الأعضاء في هذه المواقع، أما القسم الثاني: هي مواقع التواصل الاجتماعي المفتوحة للجميع، ويحق لكل من يملك حسابًا علي شبكة الإنترنت

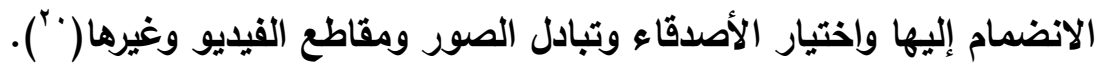
سلبيات مواقع التو اصل الاجتماعي: يستخدم الطلاب مواقع التواصل الاجتمـاعي حول العالم، بحيث أصبحت هذه المواقع

جزءا من الروتين اليومي لهم، ويالرغم من ايجابياتها وإن لها العديا من السلبيات، ومنها:

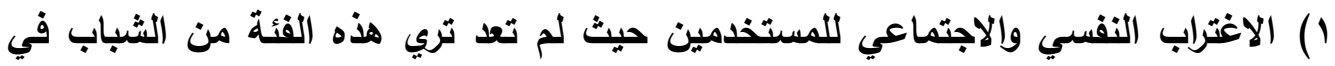

مجتمعها سوي "التخلف " مقابل "التقدم" و"التحضر " في المجتمعات الافتراضية ". r) الاغتراب الثقافي لاي الشباب ، والتباهي مع النموذج الغربي والانبهار بتقدمه وتحضره

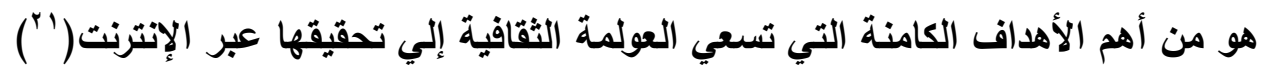
r ب أعد أداة لنشر الأخبار المغلوطة وغير الصحيحة. ء) مواقع التواصل الاجتماعي تفتح المجال لأراء غير المختصين: يعرض الكثير من المستخدمين مشكلاتهم الشخصية والصحية والاجتماعية عبر مواقع التواصل الاجتماعي، مما يفتح المجال لحلها من خلال آراء أصدقائهم ومعارفهم غير

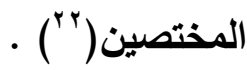

ه) تدهور الأكرة اللغوية العربية . ؟) تدمير العادات والتقاليد واللهويات الاجتماعية المحلية .

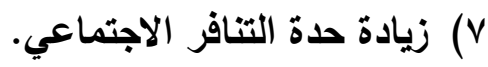




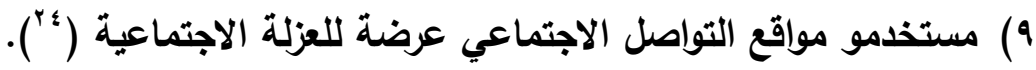

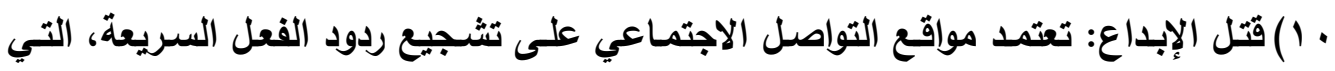
تجعلك متأهبًا للمشاركة بسرعة في أي حدث تتعارض مع كونها خلاقة، وتقتل الإبداع في ذهنك.

1) (1) الثعور بهوس المشاركة: أصـابت مواقع التواصل الكثير من النـاس بالهوس بالمشـاركة بالصور والفيديوهات، فالكثير من الناس يضع هاتفه الذكي في وضع الاستعداد من أجل بل بـن

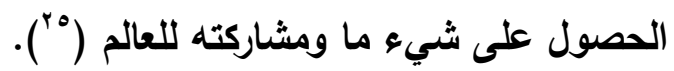

آثار التعرض لمواقع التواصل علي الجانب الديني و الأخلاقي للشباب:

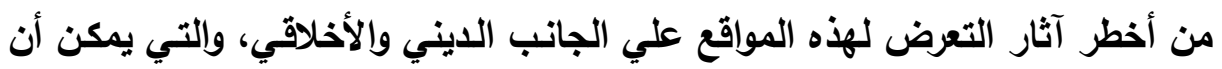

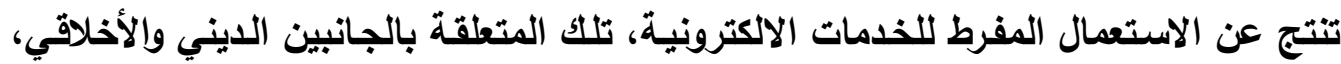
حيث إن مناقشة موضوعات غير جادة قد تؤدي إلـي تدهور منظومـة القيم، وهذا يشكل خطراً

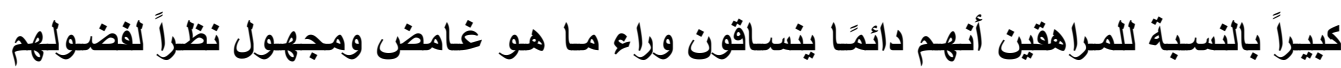

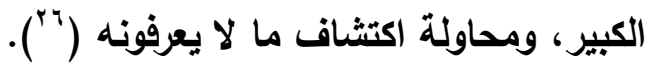
التعربفات الإجر ائية: الانتحار :

هو اعتداء الفرد علي نفسه للتخلص من حياته والذي يؤدي للوفاة نتيجة لظروف نفسية او اجتماعية او اقتصادية أو ضغوط أسرية.

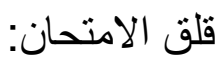
هو الشعور بالخوف المتكرر من الامتحان نتيجة لتوقع الفشل أو عدم تحقيق الهدف لأف أو لإرضاء ولجي الأمر. مشكلة الدر اسة:

لا شك أن قضية الانتحار استحوذت علي اهتمام المجتمعات بأسرها خلال الآونة

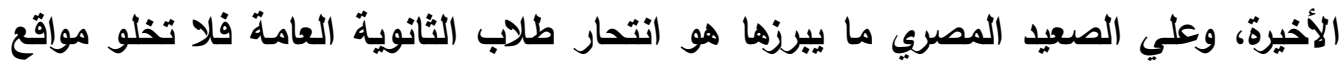
التواصل الاجتماعي من حوادث الانتحار للطلاب أثناء الامتحانات ويعد ظهور النتيجة من خلال نشر أخبار المنتحرين وعرض تفاصيل وملابسات الانتحار في نصوص وصور فوتوغرافية وفيديوهات وهو ما أكدته الإحصائيات والدراسات لأعداد الطلاب المنتحرين لدرجة أن وصلت الأعداد لخمسة منتحرين في شهر واحد في عام 1 ـ ـ ب ومن دواعي الهتمام الدولة 
بهذه القضية ما تم عرضه علي لجنة التعليم بالبرلمان المصري من خطورة هذه المشكلة وطرح الحلول للقضاء عليها، وهي من القضايا البارزة في المجتمع المصري وهي قضية ليست وليدة اللحظة ولكن يعاني منها مجتمعنا منذ أمد بعيد. ويعد قلق الامتحان من الموضوعات المهمة في العملية التعليمية التي تؤثر علي الطلاب سلباً وايجاباً فالقلق يشعرون به قبل وأثناء الامتحانات ويعد من الأمور الطبيعية الإيجابية لأي طالب إذا كان طبيعياً وينسبة مقبولة، أما إذا زاد عن معدله الطبيعي فإنه سيأخذ منحي آخر، وتظهر أعراض غير منطقية علي الطلاب مثل عدم تذكر المعلومات والخوف من الأداء المناسب لمستوي الطالب في الامتحان فيصبح بهذا المفهوم ما يسمي المي بقلق الامتحان، ومن هذا المنطلق تحاول هذه الدراسة التعرف علي العلاقة بين تعرض طلاب الثانوية العامة لأخبار انتحار الطلاب علي مواقع التواصل الاجتماعي وقلق الامتحان لايهم. الدر اسات السابقة:

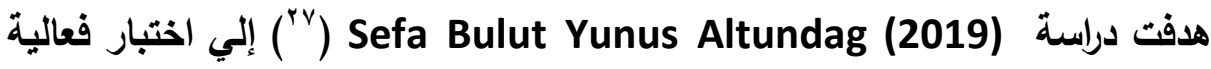
نهج المشورة على قلى اختبار لطلاب المدارس الثانوية في السنة العليا. واستخدمت الدراسة المنهج التجريبي، وأجريت الدراسة علي عينة مكونة 17 طالبًا من مدرسة الأناضول الثانوية

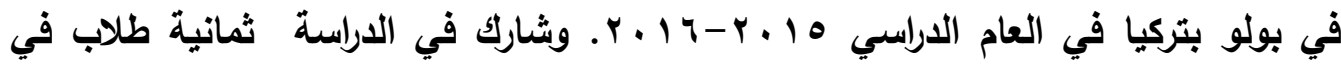
المجموعة التجريبية ، بينما شارك ثمانية آخرون في المجموعة الضابطة، تم استخدام اختبارات Mann Whitney-U و Wilcoxon Rank Rank، وتوصلت الدراسة إلي: وجود فروق ذات دلالة إحصائية بين شروط الاختبار القبلي والبعدي لصالح البعدي فقد ثبت أن هناك انخفاضًا في درجات قلث الاختبار لاى الطلاب الذين شاركوا في الاختبار النفسي بناءً

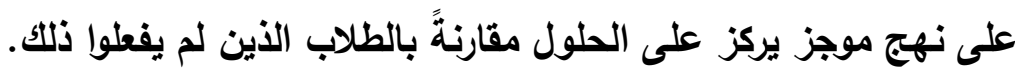

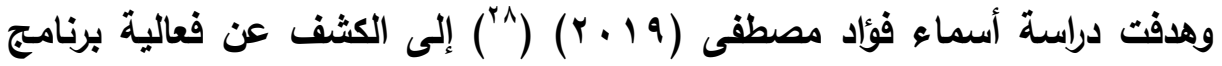
إرشادي نفسي ديني في خفض التفكير في الانتحار وتخفيف العوامل المرتبطة به (الاكتئاب-

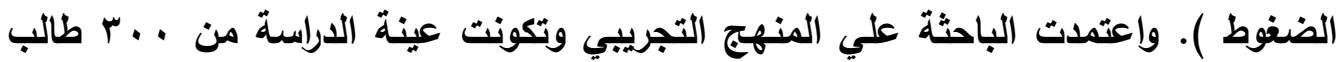

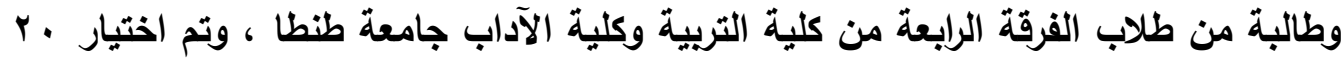
طالب وطالبة ممن سجلوا أعلى الدرجات علي مقياس التفكير في الانتحار والمحاولات الانتحارية وطبق البرنامج الإرشادي النفسي الديني على مجموعتين مجموعة تجريبية ومجموعة ضابطة، وطبق عليهم مقياس التفكير في الانتحار، وتوصلت الدراسة إلى: وجود 
علاقة ارتباطيه بين التفكير في الانتحار والاكتئاب والضغوط النفسية، كما توصلت الدراسة إلى وجود أثر للبرنامج الإرشادي النفسي الديني في خفض التفكير في الاتتحار وتخفيف العوامل المرتبطة به مثل الاكتئاب ،والضغوط النفسية.

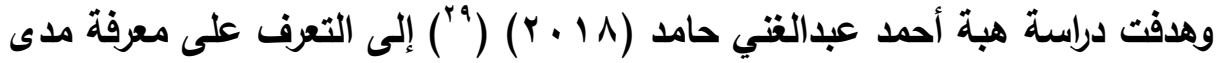
فاعلية برنامج إرشادي لتنمية الصمود النفسي للوقاية من الانتحار لاى عينة من طلاب المرحلة الثانوية واستخدمت الباحثة المنهج التجريبي، و قد تكونت عينة الدراسة الأساسية من (·11) طالب و طالبة من المرحلة الثانوية تم اختيارهم بطريقة عمديه اختير منهم منخفضي الصمود النفسي و مرتفعي احتمالية الانتحار وكانوا (Y^) طالب و طالبة تم تقسيمهم إلى (؛ 1) مجموعة تجريبية، (ع 1) مجموعة ضابطة، تم استخدام مقياس الصمود النفسي ، ومقياس احتمالية الانتحار، والبرنامج الإرشادي من (إعداد الباحثة )، و أوضحت الته

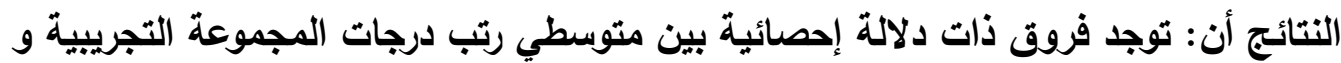
الضابطة في التطبيق البعدي على مقياس الصمود النفسي (أبعاده والدرجة الكلية) في اتجاه المجموعة التجريبية.

وهدفت دراسة (2018) Yong Li\& Junrong Shi (·") إلي التعرف علي تأثير البلطجة على الانتحار، وتأثير التنمر غير المباشر على الاتتحار من خلال الاكتئاب وتعاطي

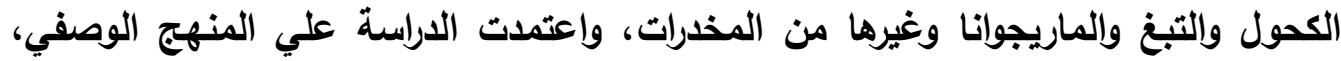

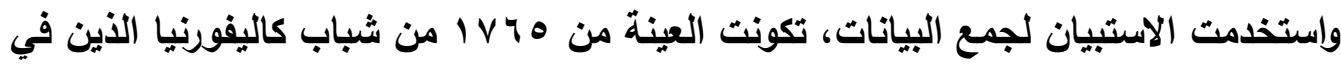

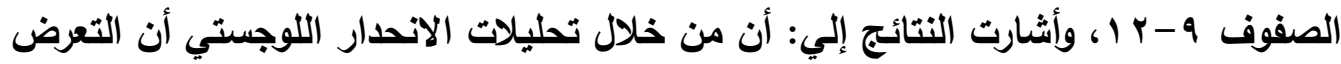
للتخويف يرتبط بزيادة احتمالات الاتتحار في جميع المجموعات العرقية، وأن الاكتئاب يتوسط التيط تأثير البلطجة على الاتتحار لجميع المجموعات العرقية، وأن تعاطي الكحول يتوسط التأثير

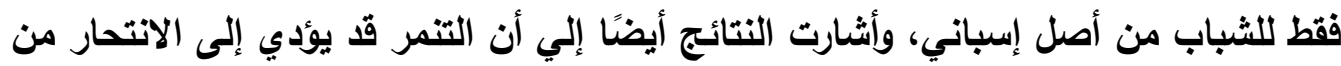
خلال سلوكيات مخاطرة مختلفة للشباب من مختلف المجموعات العرقية.

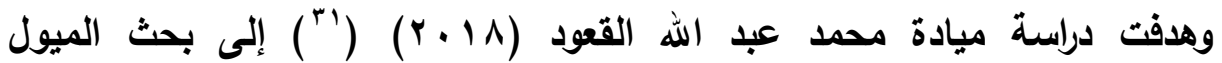
الانتحارية، والمساندة الاجتماعية لدى عينة من المتحولين جنسياً. وقد أجريت الاراسة على لهي

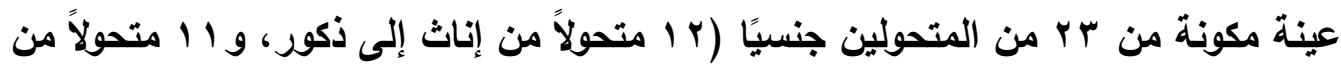

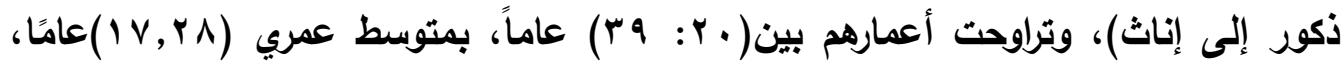


واتحراف معياري(ه,rه)عامًا. وقد أكملوا المقاييس التالية: مقياس احتمالية الانتحار، ومقياس المساندة الاجتماعية، ومقياس أوتريكت لاضطراب الهوية الجنسية، وأسفرت نتائج الدراسة عن وجود علاقة سلبية دالة بين الميول الانتحارية والمساندة الاجتماعية لاى المتحولين جنسيًا، كما ظهرت فروق دالة إحصائيًا بين مجموعة المتحولين إلى ذكور ومجموعة المتحولين إلى إناث في الميول الانتحارية، وذلك في اتجاه المتحولين إلى إناث.

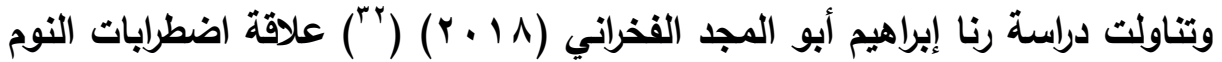
بكلٍ من الاكتئاب والميول الانتحارية، ومدى اسهام كل متغير من المتغيرات في العينة المستهدفة وهم مراهقين من طلاب الجامعة، وتقديم مزيد من المعرفة حول هذا الموضوع،

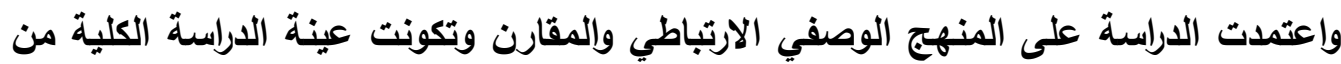

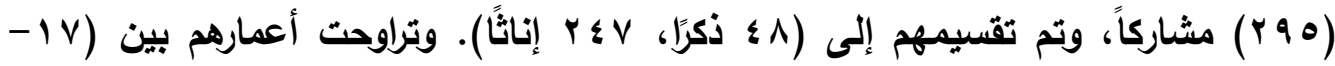

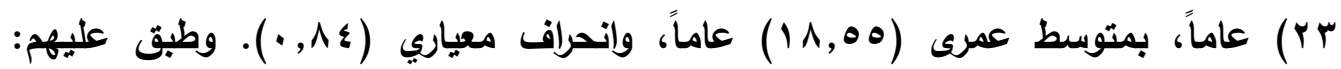
مقياس اضطرابات النوم، وقائمة بيك للاكتئاب، ومقياس احتمالية الانتحار، وأشارت نتائج الدراسة إلى أن: درجات اضطرابات النوم تُعدِل قوة العلاقة بين الاكتئاب والميول الانتحارية لاى عينة من طلاب الجامعة، وهناك فروقاً دالة إحصائية بين متوسط درجات الطلاب مرتفعي اضطرابات النوم ومتوسط درجات الطلاب منخفضي اضطرابات النوم على مقياس الاكتئاب.

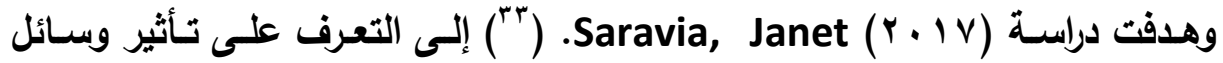
التواصل الاجتماعي على الشباب من سن · ل إلى V V عام ، والتعرف على تأثير الثبكات الاجتماعيـة على الناحيـة الاجتماعيـة والإنسـانية لــى عينـة الدراسـة ، عن طريـق استخدام أسلوب المقابلات البحثية النوعية والكمية وإستخدام مقياس الاتجاه للتعرف على الاتجاهات الاجتماعية وإلعاطفية التي تحدث بين الثباب نتيجة تفاعلهم مـع مواقع الشبكات الاجتماعية حيث طبقت الاراسة على مواقع (الفيسبوك - انستجرام - تويتر - سناب شـات ) ، وتوصلت

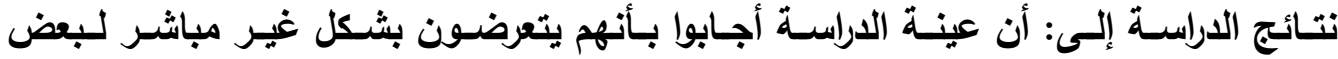
السـلوكيات غير المرغوب فيها عبر مواقِع التواصل الاجتمـاعي والتـي توئثر على علاقِاتهم

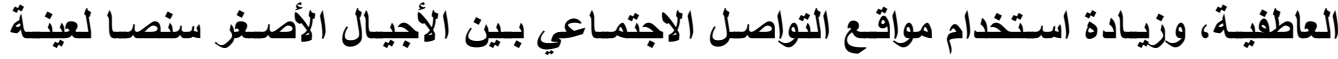

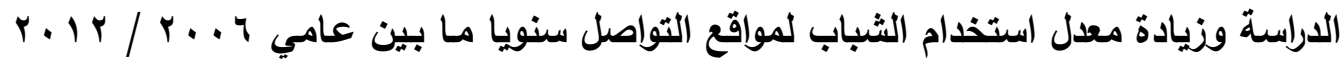




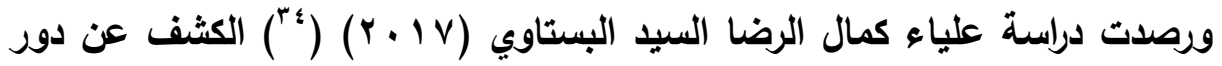
الأكاء الوجداني كمتغير مُعدِل للعلاقة بين الاكتئاب والسلوك الاتتحاري لاى عينة من الأحداث الجانحين، وكذلك بيان الفروق في كل من الذكاء الوجداني، والاكتئاب، والسلوك الانتحاري

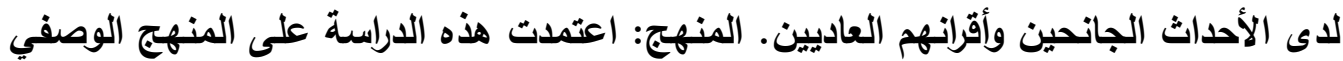

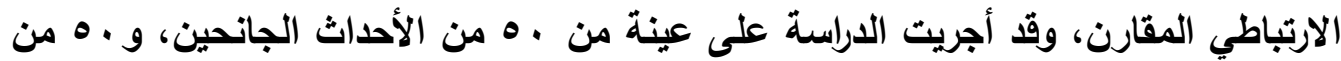
العاديين وتضمنت أدوات الاراسة مقياس الأكاء الوجداني ، ومقياس بيك للاكتئاب، ومقياس هن

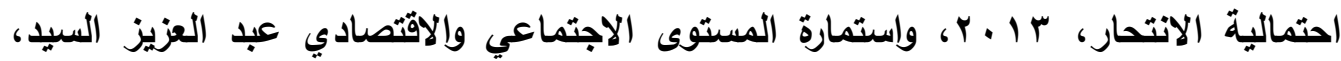

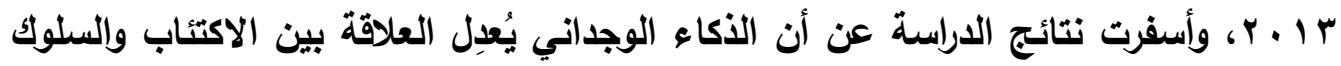
الانتحاري بين الأحداث الجانحين، بالإضافة إلى وجود فروق ذات دلالة إحصائية في الأكاء الوجداني، والاكتئاب، والسلوك الانتحاري بين الأحداث الجانحين وأقرانهم العاديين.

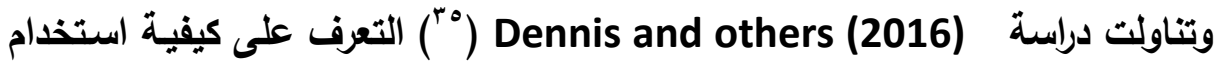
وسائل التواصل الاجتماعي لتشكيل الممارسـة السياسية في بريطانيا ، والتعرف على أسـاليب

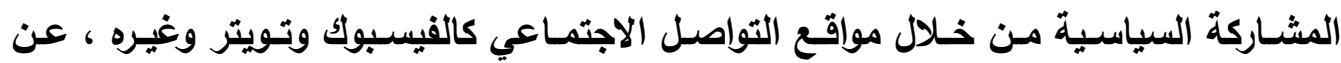
طريق تحليل مذكرات المشـاركات الإعلاميـة لعينة الدراسـة على مواقع التواصل الاجتمـاعي ، وتوصلت نتائج الدراسـة إلسى :أن الفيسوك وتـويتر يخلقـان فرصيًا جديدة للمشـاركة المعرفيـة والتعبئة السياسية ، ويـوفران مسـاحة مهمـة للمشـاركة الديمقراطيـة في بيئة الحيـاة اليوميـة، ويستخدم بعض الأفراد وسـائل التواصل الاجتمـاعي للاستفادة من المعلومـات السياسية ، كما أن البعض يمتتع عن التعبير بآرائهم بشكل عام ولكنهم قد يستخدمون المجموعات الخاصة

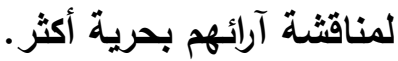

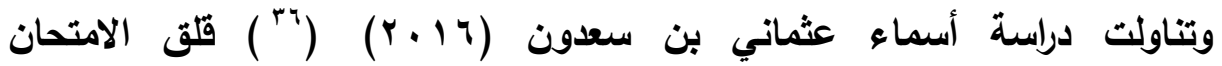
واستراتيجيات المواجهة عند طلاب الثانوية العامة، حيث هدفت إلى معرفة أكثر استراتيجيات المواجهة استخدامًا، وإن كانت هناك فروق بين الاستراتيجيات في ضوء متغيرات الجنس 7.

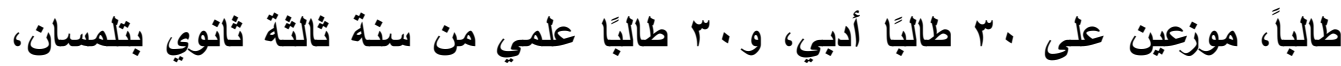
واستخدمت الباحثة مقياس قلق الامتحان لسبيلبرجر، وقامت بإعداد استبيان استراتيجيات المواجهة. وخلصت الدراسة إلى نتيجة أن إستراتيجية حل المشكلات والرجوع إلى الدين واللدعم 
الاجتماعي أكثر استخداماً. كما أظهرت النتائج عدم وجود فروق في استراتيجيات المواجهة تعزى لارجات قلق الامتحان، بينما توصلت إلى وجود فروق بين الإناث والذكور في استخدام

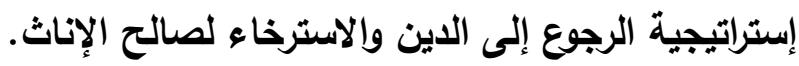
دراسة (2015) Amanda Lenhart (" (ب)، " استخدامات المراهقين لمواقع التواصل الاجتماعي وخاصة الفيس بوك " هافت الدراسة إلي التعرف علي استخدامات المراهقين لمواقع التواصل الاجتماعي وخاصة الفيس بوك ، واستخدمت استمارة استبيان وطبقت علي

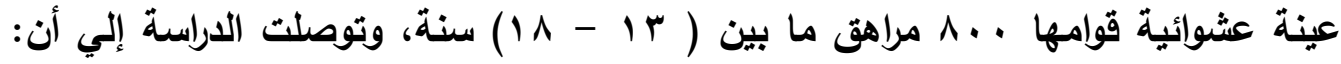

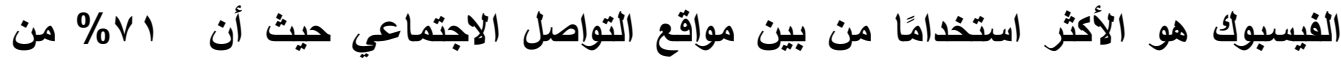

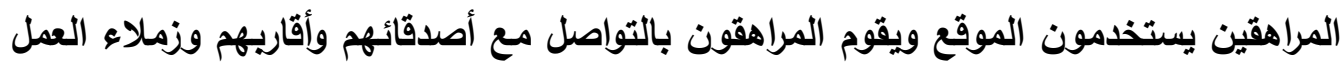
في المقام الأول ولا يوجد فروق بين الأكور والإناث في استخدامهم للفيس بوك.

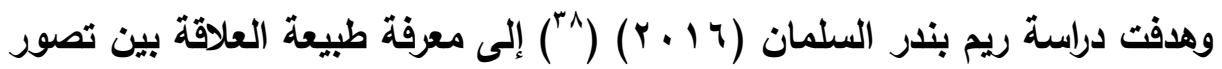
الانتحار وكل من الاكتئاب واليأس لاى عينة من طلاب جامعة الكويت، فضلاً عن التعرف على مدى انتظام تلك المتغيرات في عامل استكثافي أحادي القطب لاى أفراد العينة وقد

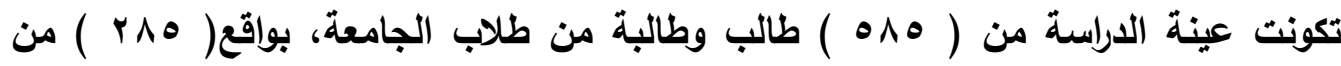
الأكور و ( . . . ) من الإناث، وإستعين بالأدوات التالية: مقياس "بيك" لليأس (BDI-II)

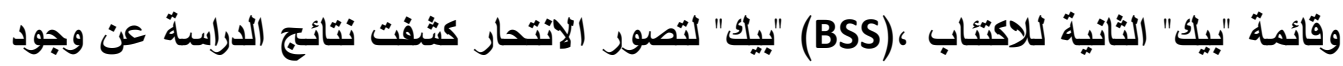

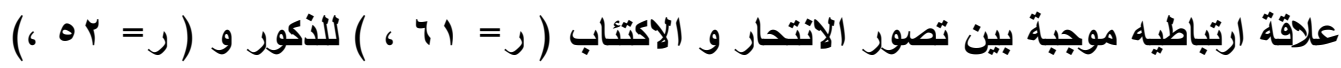
لاى عينة الإناث، كما كشفت النتائج عن وجود معاملات تثابه بين عوامل الأكور والإناث في تصور الانتحار، فضلا عن استخلاص عامل استكشافي أحادي القطب من تلك المتغيرات.

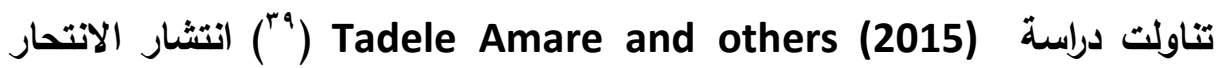
والعوامل المرتبطة به بين طلاب المدارس الثانوية المراهقين في مدينة دانجيلا ، شمال غرب

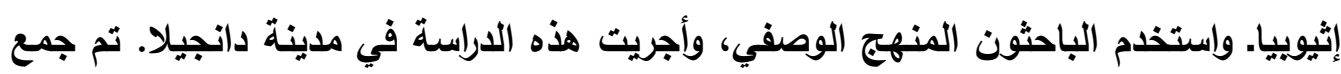
البيانات من طلاب المدارس الثانوية من المراهقين باستخدام استبيان باللغة الأمهرية، وتم

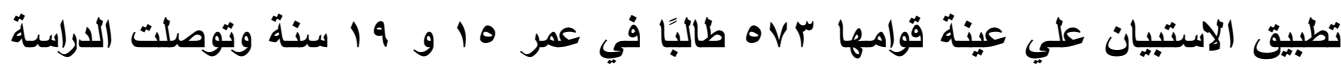

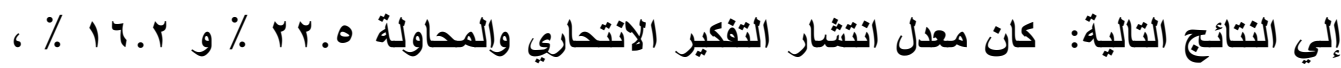
على التوالي. ارتبطت الغياب المدرسي 95\% وضعف الدعم الاجتماعي 95\% بأفكار الانتحار ولان 
، لا يوجد أي ارتباط بين الجنس أو تعاطي الكحول والأفكار أو المحاولات الاتتحارية، وكثفت هذه الاراسة أن واحدا على الأقل من كل خمسة من المراهقين في عينة لاينا قـ عانى من التفكير في الانتحار. سعت دراسة (2014) Ellison, Nicole (") إلي تعرف طبيعة العلاقات الاجتماعية التي يقيمها الثباب الجامعي على شبكات التواصل الاجتماعي استخدمت الدراسة منهج المسح عن طريق مسح لعينة عشوائية بسيطة قوامها ؛ الت مفردة من طلاب جامعة بالولايات

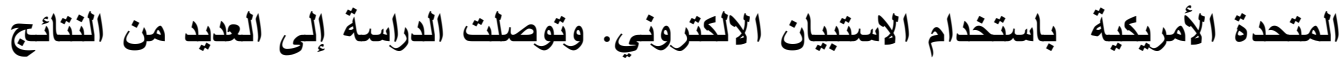

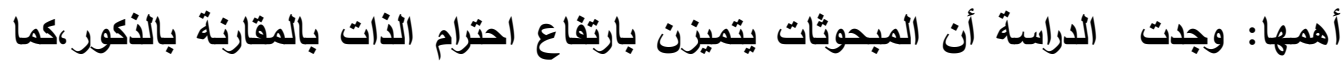

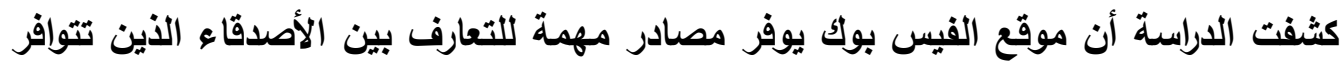
للايهم خصائص مشتركة مثل السن والتخصص. وتناولت دراسة (2014) Hilda N Shilubane and others (') تقييم معرفة الطلاب بالانتحار وعوامل الخطر المدركة وعلامات ضعف الصحة العقلية لاى المراهقين الذين

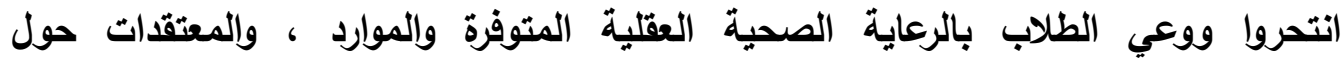
الوقاية.واستخدمت هذه الدراسة النوعية مناقشات مجموعات النقاش المركزة لاستنباط أفكار ومشاعر طلاب المدارس الثانوية الذين لايهم نظير ارتكب أو حاول الانتحار. كانت جميع

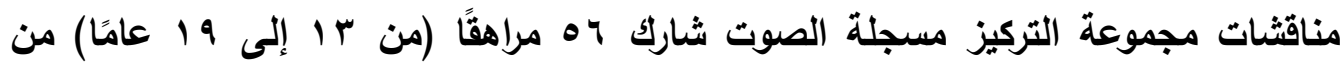
مدارس ليمبويو في جنوب إفريقيا في ستة مناقشات جماعية مركزة، وتم تحليل البيانات باستخدام المنهج الاستقرائي، وتوصلت الدراسة إلي: أن العينة تأثروا بمحاولة الاتتحار أو فئائ

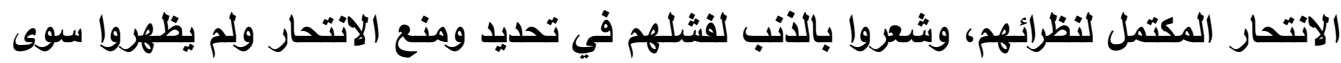
القليل من المعرفة بعلامات التحذير من السلوك الانتحاري. 
وهدفت دراسة(2015) Ann PopkessRebecca Luebbert , (

تأثير طريقة التدريس على أداء تقييم الانتحار لاى طلاب تمريض البكالوريا، واستخدمت

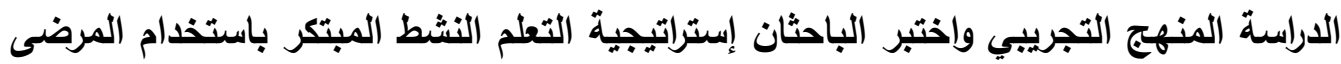
موحدة محاكاة لتحليد فعاليتها في تدريس مهارات تقييم الاتتحار لعينة من ؛ ب طالبًا من طلاب التمريض صغار وكبار التمريض. تصميم: استخدمت هذه الداسة التجريبية ، تصميم البعدي من مجموعتين وثلاث أدوات الرابطة الوطنية للتمريض / تقييم محاكاة ليردال، وأظهرت النتائج: أن تفوق المجموعة التجريبية بفرق كبير في درجات الطلاب من الثقة بالنفس والرضا وتصورات الطلاب عن الممارسات التعليمية (التعلم النشط والتعاون والنداء لأساليب التعلم المتنوعة) عند مقارنتها بتنسيق المحاضرة.

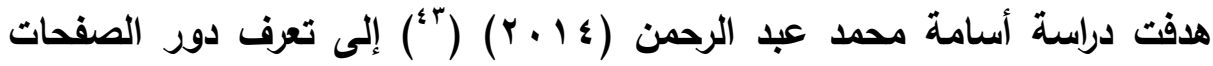
الإخبارية بالفيس بوك في إمداد الثباب الجامعي بالمطومات عن الأحداث الجارية، وتنتمي

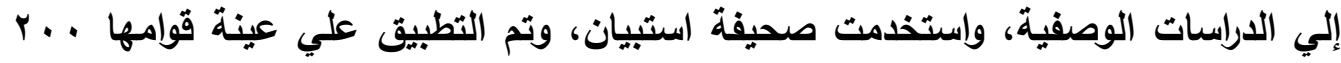

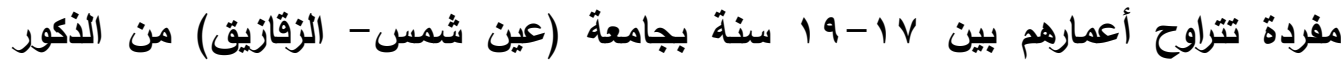
والإناث، وخلصت الدراسة إلى ارتفاع نسبة استخدام الفيس بوك بين أفراد العينة بنسبة

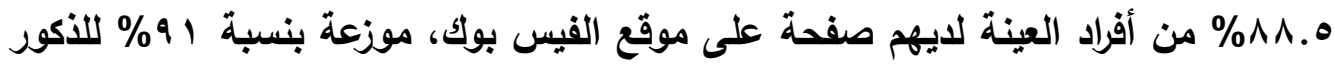

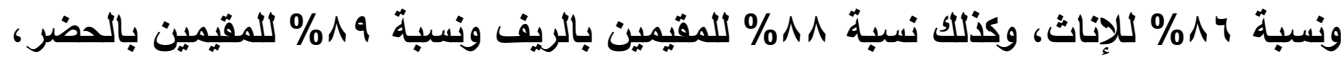

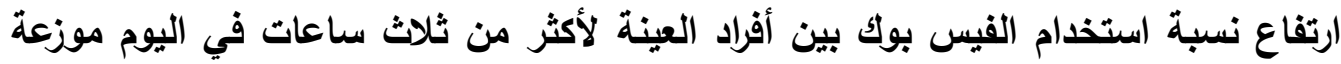

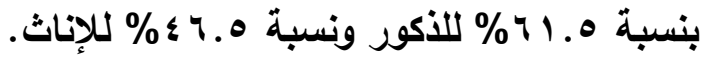

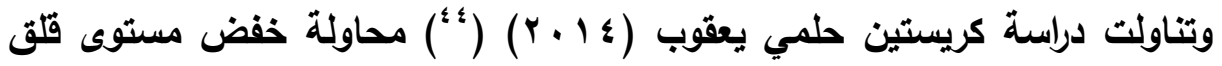
الامتحان لاى طلاب الجامعة عن طريق تقتية حديثة هي تقنية التفذية الراجعة الحيوية واعتمدت الدراسة علي المنهج التجريبي، وكانت العينة المستخدمة تتضمن مجموعة كلية قوامها (• ؛ ) طالبًا وطالبة من طلاب الفرقة الرابعة بكلية التربية جامعة عين شمس أقسام

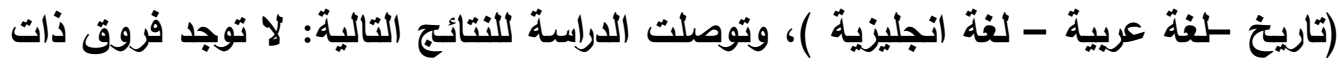

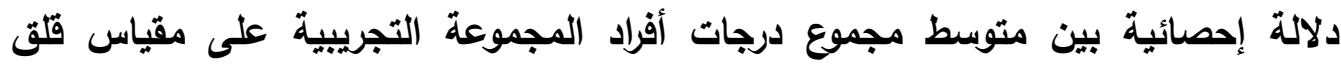

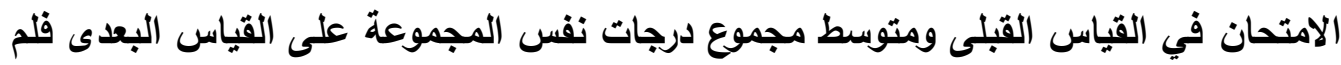
يتحقق الفرض الأول، ولا توجد فروق ذات دلالة إحصائية بين متوسط مجموع درجات أفراد 
المجموعة التجريبية على مقياس قلق الامتحان في القياس البعدى ومتوسط مجموع درجات نفس المجموعة على القياس التتبعى، ولا توجد فوق ذات دلالة إحصائية بين متوسط درجات كل من الأكور والإناث فى مستوى قلق الامتحان.

وهدفت دراسة (2013) Parra Uribeac H .Blasco -Fontecilla

تقديم توصيف أكثر دقة من خلال مقارنة مجموعات من محاولي الانتحار والمكملين من نفس

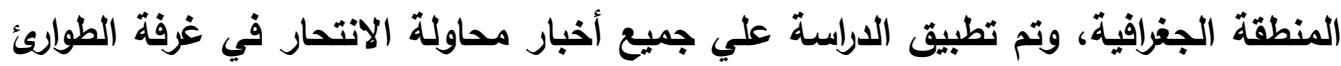
في مستثفيات Corporacio Sanitària i Universitària Tauli Parc de Sabadell

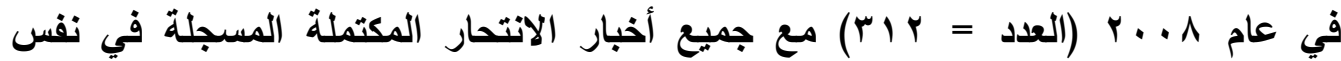

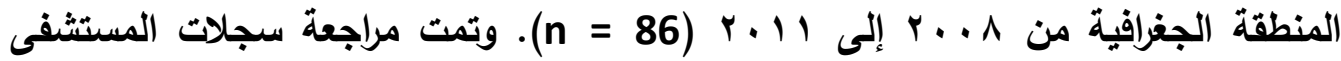
والرعاية الأولية للمتفيرات الاجتماعية والديموغرافية والسريرية، بمقارنة بمحاولي الاتتحار

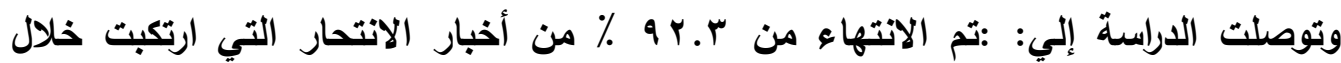
المحاولة الأولى أو الثانية.

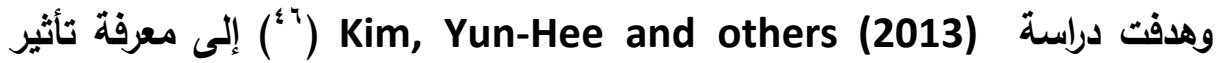
ضغوط الحياة لاى طلاب الجامعة على التفكير في الانتحار والتحقق من التأثير الوسيط للصحة النفسية الشخصية على العلاقة بين ضغوط الحياة والتفكير في الانتحار. لذلك جمعت الت الت هذه الدراسة بيانات من 9 ه؛ طالبًا جامعيًا مسجلين في ؛ جامعات تقع في مدينة دايجون مترويوليتان وتثونجنام وتشونجبوك. وتوصلت الدراسة إلي ما يلي: كان لإجهاد الحياة والتفكير في الانتحار والصحة العقلية علاقة ذات دلالة إحصائية. ثانيًا ، لا يؤثر إجهاد الحياة بشكل مباشر على التفكير في الانتحار فحسب ، بل يحدث تأثيرًا غير مباشر من خلال متغير الوسيط ، والصحة العقلية ، وتثير نتائج البحث إلى أن الصحة العقلية لطلاب الجامعة تعاني

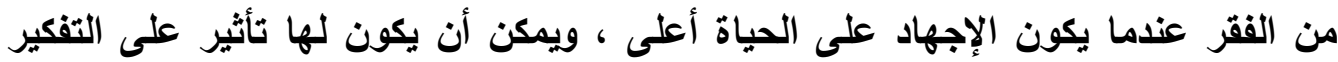
الانتحاري بسبب استمرار ظاهرة فقان الوظيفة العامة للحياة.

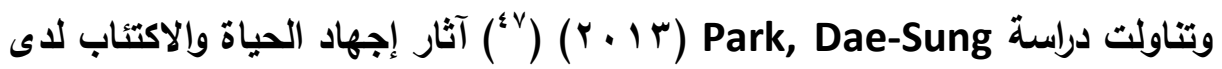
طلاب كلية الطب على تفكيرهم في الانتحار: التحكم في آثار الدعم الاجتماعي وتم تطبيق

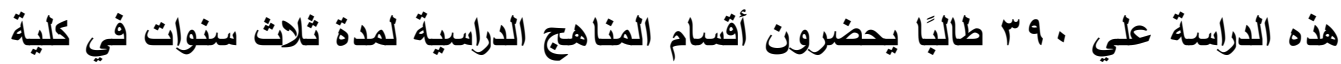
جي في مدينة جي الحضرية ، بما في ذلك تكنولوجيا الطوارئ الطبية والعلاج الطبيعي وإدارة 


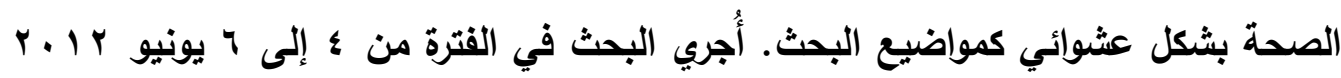
باستخدام استبيان منظم مُدار ذاتيًا ، وتوصلت الدراسة إلي أن: آثار التفاعل بين الاكتئاب من التفكير الانتحاري والدعم الاجتماعي أظهرت وجود علاقة سلبية وكان لها دلالة إحصائية.

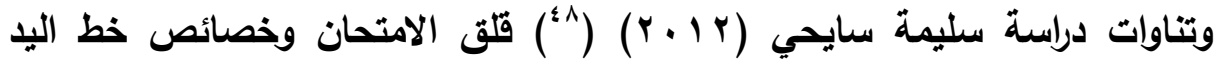

للتلاميذ. ويهدف إلى تحديد بعض خصائص خط اليد لاى التلاميذ ذوي مستوى قلق الامتحان المرتفع، باستخدام علم الجرافولوجيا أو علم تحليل الخط. وتكونت عينة البحث من . 11 تلميذا وتلميذة من تلاميذ الصف الثالث ثانوي بمدينة بسكرة، اختيروا من بين 17 اء ممن حصلوا على درجات مرتفعة على مقياس مكونات قلق الامتحان. وتراوحت أعمارهم الزمنية

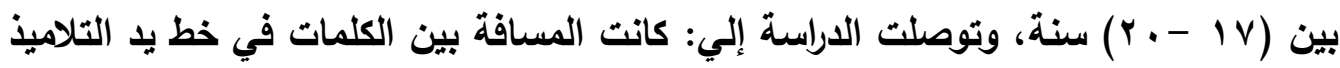
ذوي مستوى قلق الامتحان المرتفع صغيرة إلى متوسطة - ـكانت المسافة بين السطور في

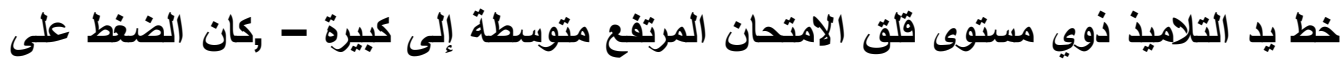
الورق في خط يد التلاميذ ذوي مستوى قلق الامتحان المرتفع شديد ثقيل - عدم وجود فروق إنق دالة إحصائيا بين الجنسين من ذوي مستوى قلق الامتحان المرتفع في بعض خصائص خط اليد (الضغط على الورق، والمسافة بين الكلمات والسطور في خط اليد، شكل خط اليد، حجم خط اليد.

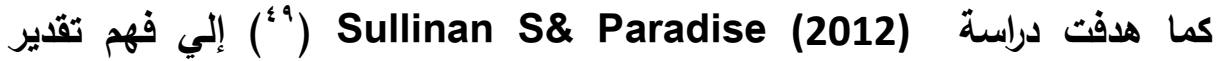
الشباب للآثار السلبية علي أنفسهم وعلي غيرهم نتيجة لاستخدام الفيسبوك، وتكونت عينة

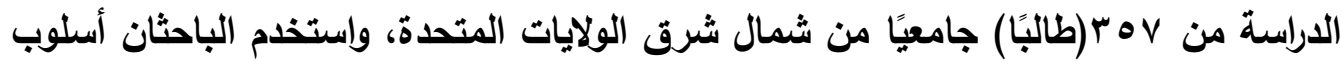

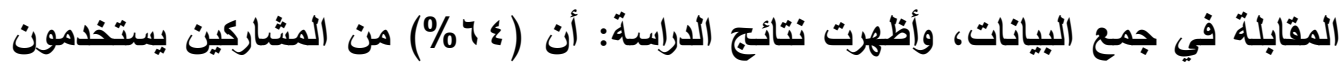
الفيسبوك سبعة أيام في الأسبوع، وأن متوسط دخول المشتركين إلي الفيسبوك هو (Y.VT)

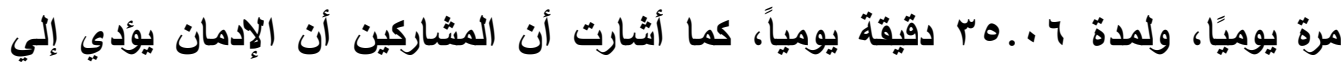

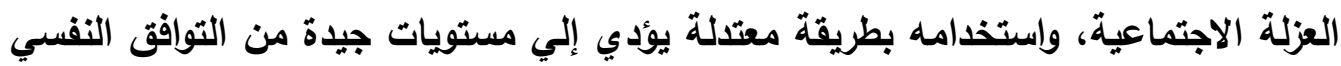
والاجتماعي.

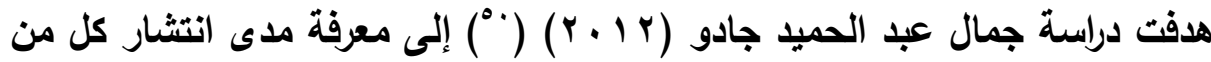
احتمالية الانتحار والمعتقدات ما وراء المعرفية لدى عينة من طلاب الجامعة، ومعرفة الارتباط بين احتمالية الانتحار والأفكار ما وراء المعرفية ودراسة الفروق بين الأكور والإناث في كل وله 
من احتمالية الانتحار والأفكار ما وراء المعرفية، وتنتمي هذه الاراسة إلي الدراسات الوصفية،

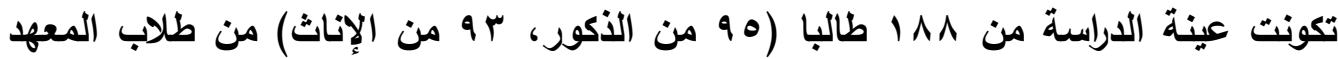
العالي للخدمة الاجتماعية بأسوان، استخدم معهم مقياس احتمالية الاتتحار لعبد الرقيب من من الإبات البحيري ومقياس ما وراء المعرفة لويلز (تعريب الباحث) والبرنامج العلاجي من إعداد الباحث الحالي. وتوصلت الدراسة إلى أن: المعتقات ما وراء المعرفية وأبعادها الفرعية تنتشر بنسب الفب متوسطة ومرتفعه، وتتنشر احتمالية الاتتحار بنسب متوسطة وأقل من المتوسطة، كما وجدت

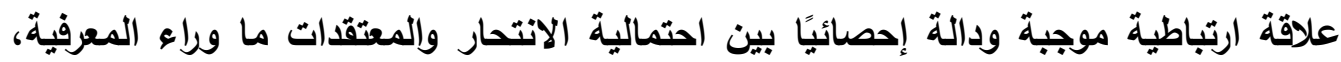
ووجدت فروق دالة إحصائيا بين الذكور والإناث لصالح الإناث في كل من احتمالية الانتحار والمعتقدات ما وراء المعرفية.

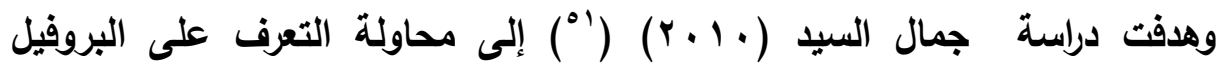
الثخصي لمحاولي الاتتحار وأيضا خفض مستوى السلوك الاتتحاري لايهم، واعتمد الباحث

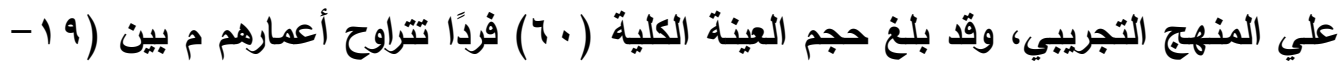
؟ آ) سنة منقسمين إلى مجموعتين متساويتين في العدد المجموعة الأولى من محاولي الانتحار بالفعل والثانية من العاديين ثم تم اختيار سبعة أفراد من المجموعة الأولى للجانب العلاجي وطبقت على العينة الكلية الأدوات التالية مقياس احتمالية الانتحار ، اختبار الشخصية المتعدد الأوجه ، اختبار اليا الاسقاطى، كما طبق البرنامج العلاجي على أفراد العينة العلاجية، وأظهرت النتائج أن هناك مجموعة من العلامات التثخيصية لمحاولي

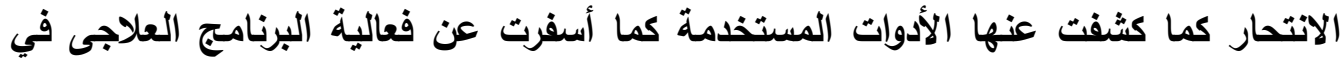
خفض مستوى السلوك الانتحاري.

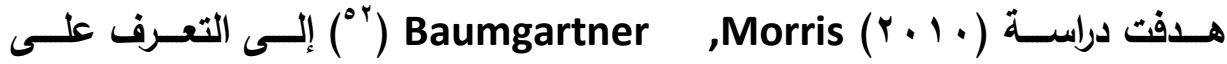
الاستخدامات السياسية للشبكات الاجتماعية مـن قبل المبحوثين ، والمتمثلة في اليوتيوب،

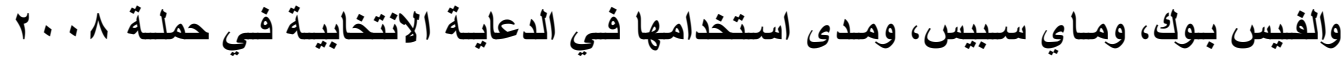
للائاسـة الأمريكيـة ، واســتخدمت الدراسـة مـنهج المســح الإعلامسي ، وتـم تطبيـق اســـمارة

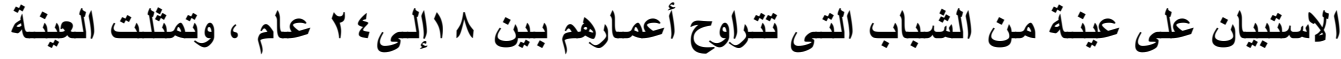
في . . ه r مفردة من الثباب ، وتوصلت الدراسـة إلى : أن مواقع التواصل الاجتماعي تؤثثر

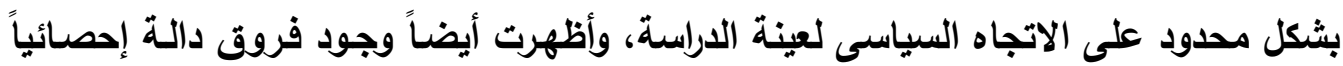




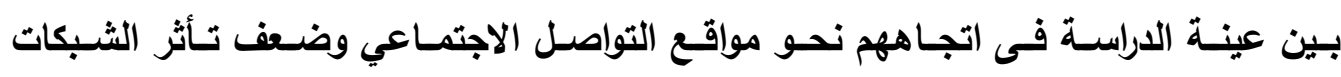

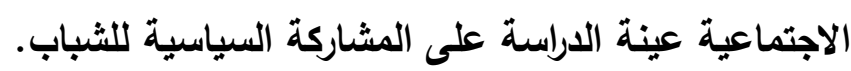

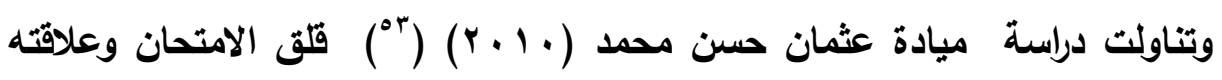
بالتحصيل الاكاديمى لاى عينة من طلاب جامعة السودان كلية التربية ومدى معرفة الفروق بين كل من الطلاب والطالبات في كل من قلق الامتحان والتحصيل الاكاديمى. قامت الباحثة

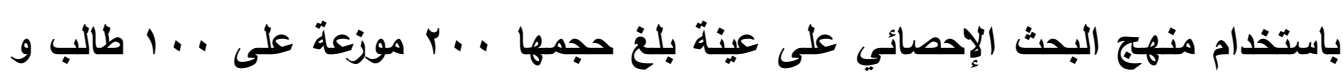

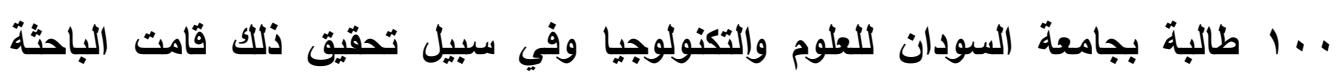
باستخدام قلق الامتحان للعالم اسبيرجر وتوصلت الباحثة إلي النتائج التالية: توجد علاقة

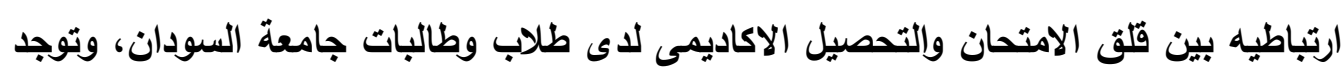

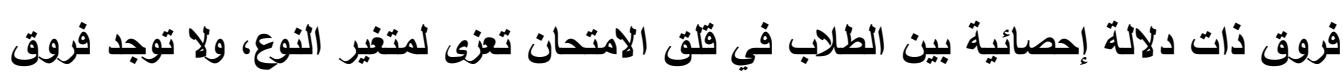

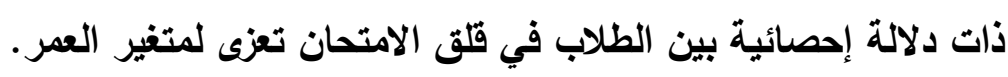
هدفت دراسة (2009) Hall (") إلي التعرف علي دوافع استخدام الثباب الجامعي لشبكات التواصل الاجتماعي وعلاقته بصفاتهم الشخصية، وتنتمي هذه الدراسة إلي الدراسات الوصفية

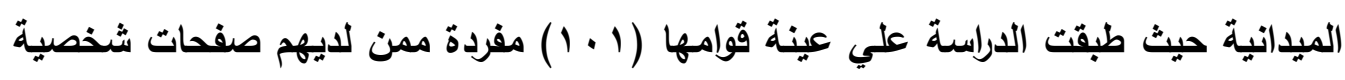

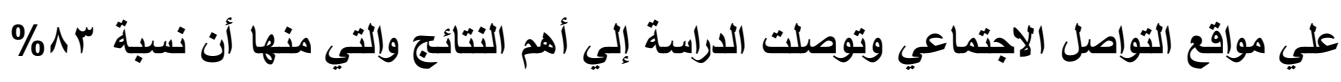

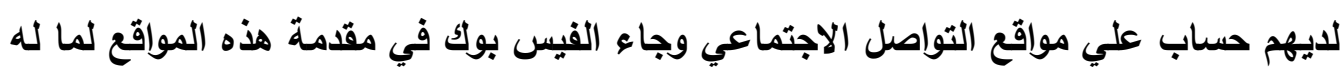

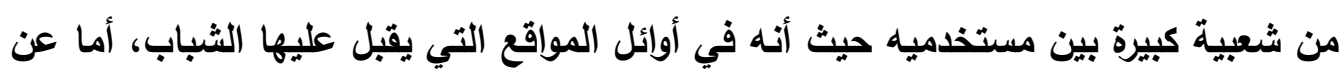

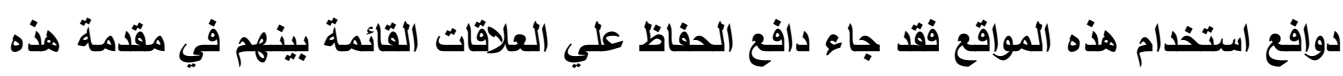
الدوافع تلاه قضاء الوقت والحصول علي المعلومات . ماهو

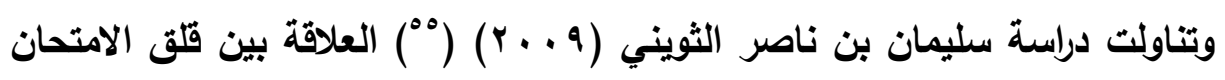
والتخصص الأكاديمي والمستوى الدراسي لطالبات جامعة حائل، واعتمد الباحث علي المنهج

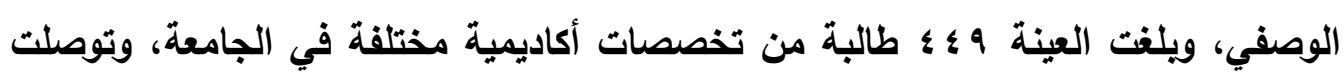

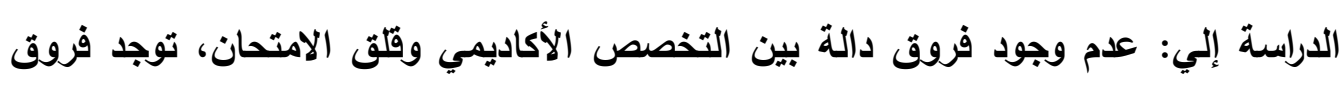
دالة بين المستوى الاراسي وقلق الامتحان لطالبات السنتين الاولى والثانية. 
وتتاولت دراسة(2007) HyunsanCho (4) العلاقة بين بلاية تعاطي المخدرات

وعوامل الخطر المتعلقة بالانتحار. واعتمدت الدراسة علي المنهج الوصفي، وتم تطبيق الاراسة علي ror ror مراهقًا في منطقتين بالمدارس الحضرية واستخدم الباحث استمارة الاستبيان، وتوصلت الدراسة إلي: أن الباية المبكرة لتعاطي المخدرات بين الأولاد كانت مرتبطة بكل عوامل خطر الانتحار الخمسة. بالمقارنة ، بين الفتيات ،وكان البدء المبكر

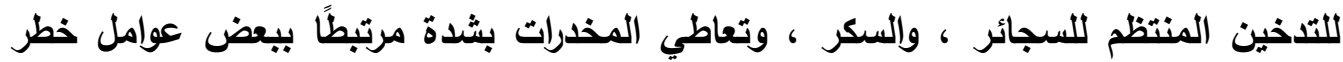
الانتحار .

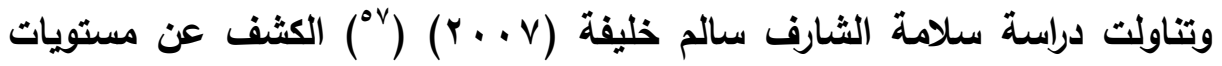

قلق الامتحانات لاى أفراد العينة حسب تخصصاتهم الدراسية، والكثف عن اضطرابات النوم لاى أفراد العينة حسب تخصصاتهم الاراسية، ودراسة العلاقة الارتباطية بين مستويات قلق الامتحان واضطرابات النوم لاى أفراد العينة حسب تخصصاتهم الدراسية ، ودراسة دلالة الفروق بين درجات أفراد العينة في كل من مستويات قلق الامتحان واضطرابات النوم،

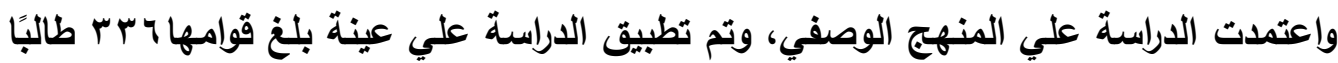
علوم تطبيقية و VT طالباً علوم إنسانية تم اختيار العينة نسبية طبقية بطريقة عشوائية وينسبة تزيل على ·r\% من المجتمع الأصلي في كل كلية من الكليات ، وتوصلت الدراسة إلي: لا توجد علاقة ارتباطيه عند مستوى الدلالة الإحصائية بين مستويات قلق الامتحان واضطرابات النوم لاى أفراد العينة الكلية، ولا توجد علاقة ارتباطيه عند مستوى الدلالة الإحصائية بين مستويات قلق الامتحان واضطرابات النوم لاى أفراد عينة الدراسة.

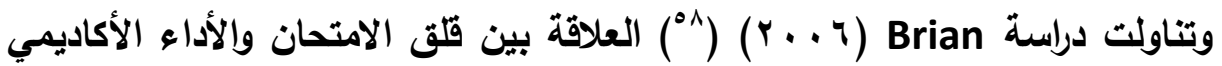
لاي طلاب الجامعة، وهدفت إلي التنبؤ بأثر قلق الامتحان والأداء الأكاديمي لاي طلاب

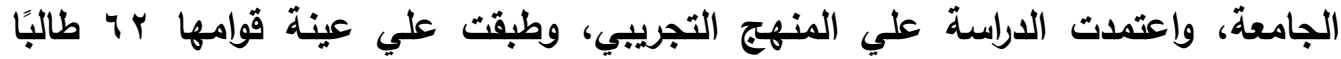
وطالبة اه طالبًا و 1 ا طالبة، وإستخدم الباحث مقياس قلق الامتحان وتم تطبيقه علي مجموعتين عالية القلق ومنخفضة القلق، وتوصلت الدراسة إلي: عدم وجود فروق بين الأداء الأكاديمي للمجموعتين، وكان تأثير القلق علي المجموعة التي أعطت امتحاناً مفاجئاً أكثر الثر منه عند المجموعة الأخرى، كما كثفت الاراسة أن القلث المرتفع يؤثر سلبًا علي التحصيل، بينما لم يكن هذا الأثر في حالة القلق المنخفض في الامتحان. 
وهدفت دراسة (2005) Takahashi \& Newmen ( ) (إلي التعرف علي العلاقة

بين القلث الامتحاني والأداء المدرسي، واعتمد الباحثان علي المنهج الوصفي، واستخدمت

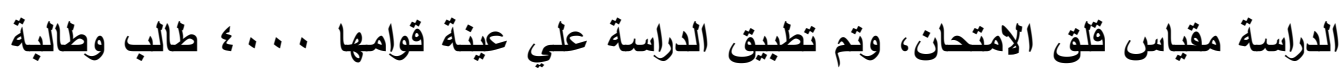

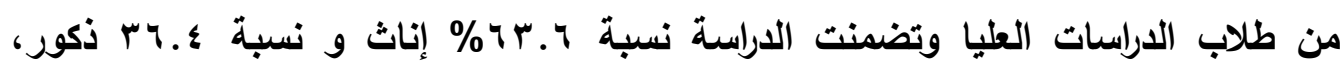
وتوصلت الدراسة إلي: وجود علاقة عكسية بشكل بسيط بين القلق الامتحاني ومعدل العلامات

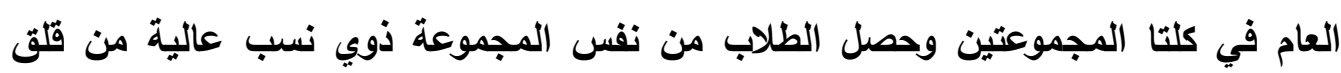
الامتحان العالي، ولكن لم يكن هناك اختلاف كبير في معدل العلامات بين الذكور في

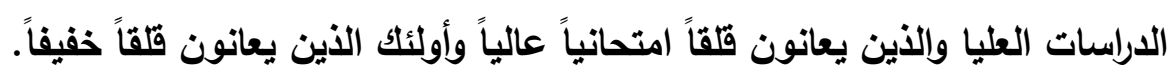

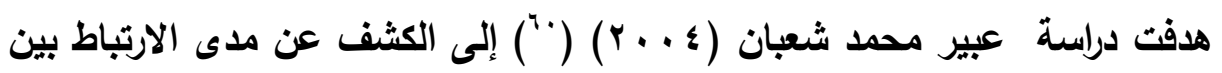

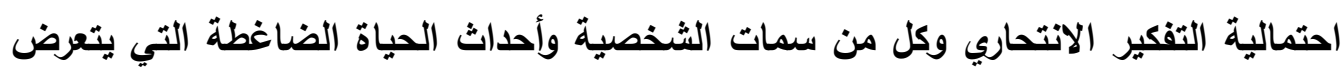
لها عينة من المراهقين من طلاب وطالبات المرحلة الثانوية، والتعرف على الفروق بين الأكور والإناث من المراهقين في كل احتمالية التفكير الانتحاري، أحداث الحياة الضاغطة.

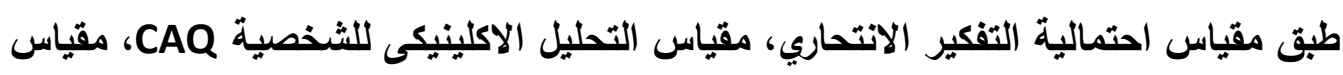

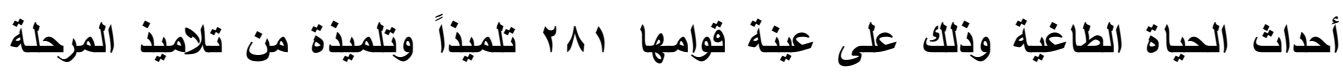
الثانوية العامة: ثلاث مدارس للأكور وثثلاث مدارس للإناث وذلك في مدينة سوهاج، وتوصلت ولثان

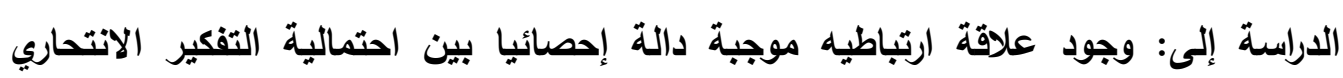

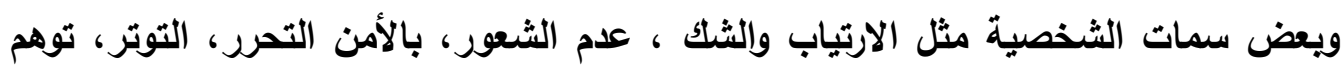

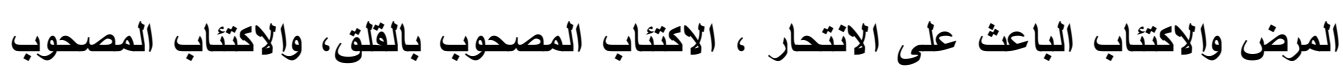
بالطاقة المنخفضة.

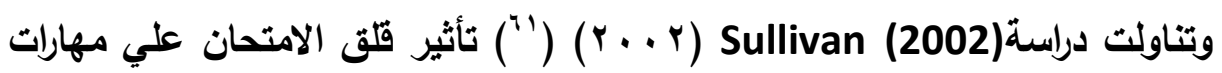
الانتباه والذاكرة لاى طلاب الجامعة، وهدفت إلى فحص تأثثر مستويات القلق العالية على التي

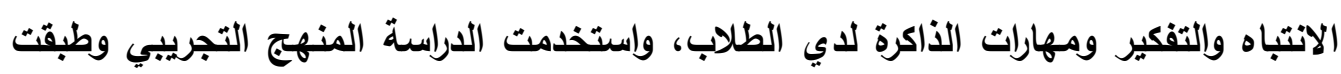

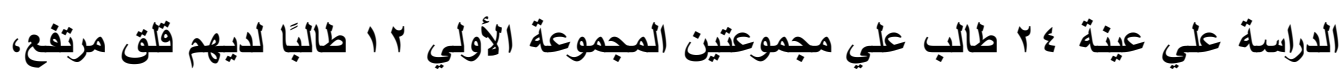

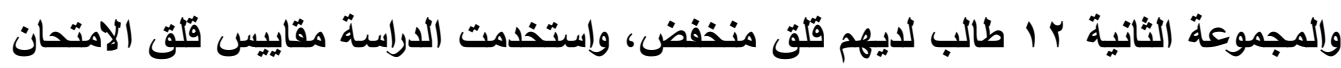

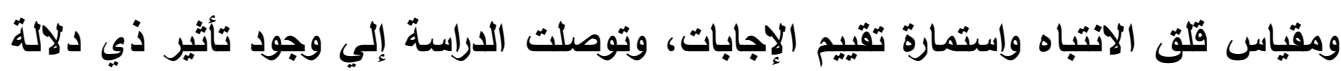


إحصائية لقلق الامتحان المرتفع علي الانتباه ومهارات الذاكرة وقد بدأ هذا الأثر بصورة انشغالات فكرية وصعوية التذكر لقائمة الكلمات التي كانت تعطي للمفحوصين. وهدفت دراسة(2001) Cassady (r) ("إني بحث مدي استقرار مستويات قلى الامتحان المعرفي عبر الزمن من خلال نماذج الامتحان، وتنتمي هذه الدراسة إلي الاراسات الوصفية، وتم تطبيق الاراسة علي عينة مكونة من \& ؟ طالبًا من الطلاب غير المتخرجين بقسم علم النفس التريوي التمهيدي في ولاية (بيل) في الولايات المتحدة الأمريكية، وإعتمدت الدراسة علي مقياس قلث الامتحان، وتوصلت الدراسة إلي أن مستوي القلق المعرفي ثابت عبر الزمن علي الرغم من الاختلافات في نماذج اختيار المنهج، وأن مستوى القلق عبر التهي الامتحان المنزلي لا يختلف بشكل عام عن مستوي القلق الحاضر عبر الاختبار الفعلي المتعدد الاختيارات. التعليق علي الدر اسات السابقة: () من خلال العرض السابق للاراسات السابقة تبين الانتشار الكبير لمواقع التواصل الاجتماعي وخاصة موقع الفيس بوكى، وزيادة استخدامهم لها r) اعتمدت معظم الاراسات السابقة الخاصة بقلق الامتحان وإلاراسات الخاصة بالاتتحار علي المنهج التجريبي، أما الدراسات الخاصة بمواقع التواصل فاعتمدت على المنهج الوصفي بشقيه التحليلي والميداني. r) اهتمت دراسات قلق الامتحان بالنواحي التعليمية أما دراسات مواقع التواصل والاتتحار فتنوعت اهتماماتها. ع) اعتمدت معظم دراسات قلق الامتحان على المقاييس المختلفة للحصول على درجات قلق الامتحان للعينات المأخوذة.

0) اعتمدت معظم دراسات مواقع التواصل على الاستبيان وتحليل المضمون كأدوات لجمع البيانات 7) ربطت العديد من دراسات الانتحار بينه وبين الاكتئاب. V لم تتطرق الدراسات السابقة إلى الربط بين مواقع التواصل الاجتماعي بقلق الامتحان. 


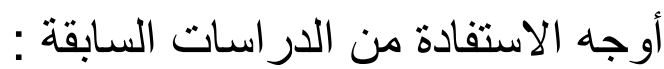

(1) ساعدت الدراسات السابقة في جعل الباحث علي دراية بما وصل إليه العلم في نقطه البحث ، ومن ثم ساهم ذلك في تحليد ما يمكن أن تضيفه الدراسة الحالية إلى التراث العلمي والأكاديمي مان

r) تحديد ويلورة المشكلة البحثية وصياغة الأهداف وتحديد المتغيرات الخاصة بالدراسة .

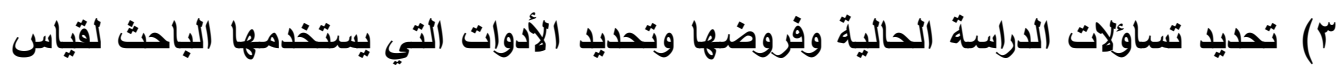
الفروض والإجابة علي التساؤلات ووضع إطار عام لما يجب أن تكون عليه الدراسة وما يمكن أن تضيفه. ؛) تحديد الإطار المنهجي واختيار المنهج المناسب لتناول موضوع الدراسة. •) الوقوف علي الإطار النظري المناسب للبحث. ؟) تصميم استمارة الاستبيان الخاصة بالدراسة من حيث تحديد أهم النقاط التي يجب أن تتناولها الاستمارة والتركيز عليها فروض الدر اسة: تسعى الاراسة إلى اختبار صحة الفروض التالية: لا توجد فروق ذات دلالة إحصائية بين عينة الاراسة من حيث المتفيرات الايموجرافية

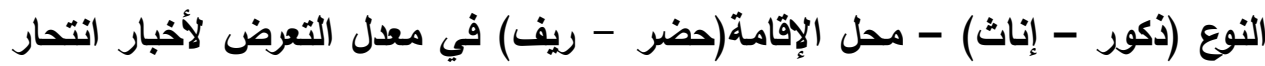
الطلاب علي مواقع التواصل الاجتماعي. r توجد علاقة ذات دلالة إحصائية بين درجة تعرض الطلاب لأخبار الانتحار علي مواقع التواصل الاجتماعي ودرجة الثقة في ما تعرضه من أخبار.

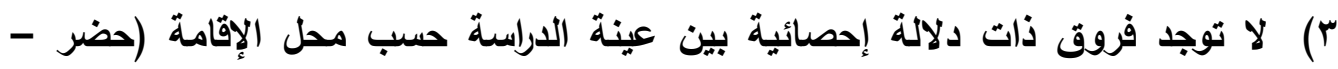
ريف) في درجة الثقة في الأخبار التي تعرضها مواقع التواصل الاجتماعي.

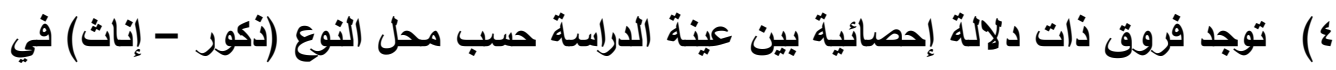
درجة الثقة في الأخبار التي تعرضها مواقع التواصل الاجتماعي.

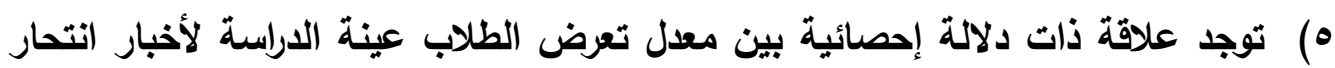
الطلاب علي مواقع التواصل الاجتماعي ودرجة قلق الامتحان. 
آ) لا توجد فروق ذات دلالة إحصائية بين عينة الدراسة حسب المتغيرات الايموجرافية النوع

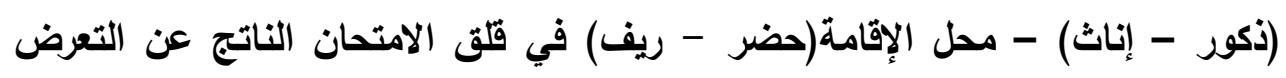

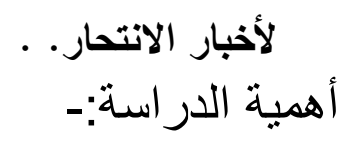
تبرز أهمية الاراسة للأسباب التالية:-

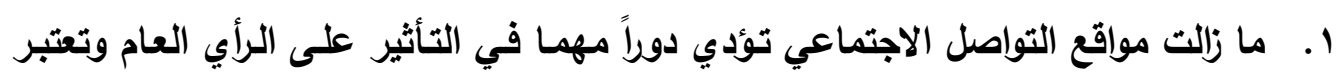

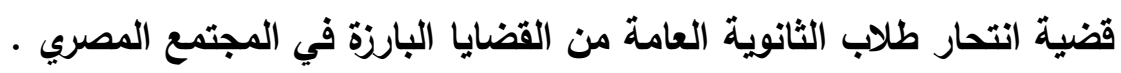

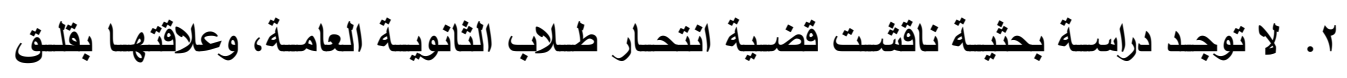
الامتحان.

r. أهمية الفئة التي يتناولها البحث وهي طلاب الثانوية العامة لأنها تمثل المرحلة الانتقالية إلي الجامعة وهي التي تحدد مصير الطالب.

ع. تصدي البحث لقضية قلق الامتحان وهي من أكثر الظواهر بين طلاب الثانوية العامة.

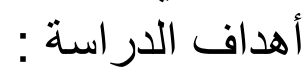
1- معرفـة درجـة متابعـة عينـة الدراسـة لقضسية انتــار طـلاب الثانويـة العامـة على مواقـع التواصل الاجتماعي.

r - الكشف عن أسباب متابعة المواقع وأسباب عدم المتابعة. r- قياس مدي القلق بالنسبة لعينة الدراسة بالنسبة لهذه القضية.

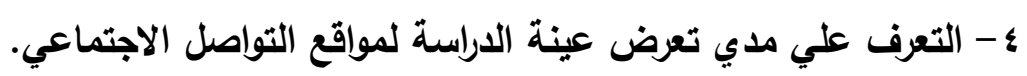
ه - معرفة الفروق بين الجنسين في مستوي قلق الامتحان الذي يسببه متابعة أخبار انتحار الطلاب.

צ- تطبيق مقياس لقلق الامتحان يستخدم كأداة قياس في البحث الحالي. نوع ومنهج الدر اسة: منئ:

تنتمي هذه الدراسة إلى الدراسات الوصفية، لأنها تسعى إلى وصف وتحليل واقع العلاقة

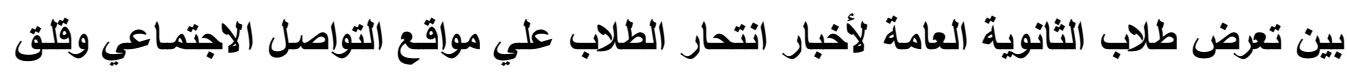

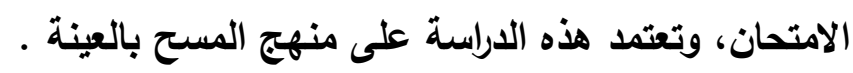

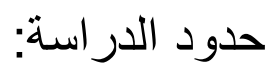
الحدود الموضو عية: تناقش الدراسة قضية انتحار طلاب الثانوية العامة. 
الحدود المكانية: طبق الباحث الاستبيان علي مدينة المنيا (ريف - حضر)

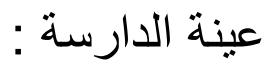
طبق الباحث دراسته على عينة عشوائية متاحة قوامها ( . . ؛ طالب وطالبة من طلاب الثانوية العامة بمحافظة المنيا (مدارس الريف - مدارس الحضر)، وركزت الاستمارة علي عدة محاور: متابعة العينة لمواقع التواصل الاجتماعي، ودرجة الاهتمام بمتابعة أخبار انتحار

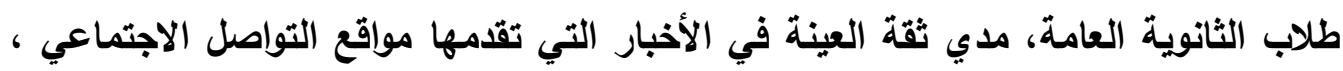
وروئة العينة عن تحديد من المسئول عن وصول الطالب للانتحار، وقياس ردود أفعال الطلاب تجاه المواقع التي تعرض هذه الأخبار، والتعرف علي الصورة التي يكونها أفراد العينة عن طلاب الثانوية العامة المنتحرين، عن قياس مستوى قلق الامتحان للعينة الناتج من تعرضهم لأخبار الاتتحار.

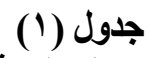

توصيف العينة:

\begin{tabular}{|c|c|c|c|}
\hline النسبة \% & التكرار & \multicolumn{2}{|c|}{ توصيف عينة الاراسة } \\
\hline or,o & Y. & ذكر & \multirow{3}{*}{ النوع } \\
\hline$\varepsilon V, 0$ & 19. & أنثي & \\
\hline$\% 1 \ldots$ & $\{\ldots$ & الإجمالي & \\
\hline$\leqslant 0, r$ & 111 & ريف & \multirow{3}{*}{ حل الإقامة } \\
\hline $0 \leqslant, \wedge$ & Y1q & حضر & \\
\hline$\% 1 \ldots$ & $\varepsilon \ldots$ & الاحمالى & \\
\hline
\end{tabular}

يتضح من الجدول السابق ما يلي:

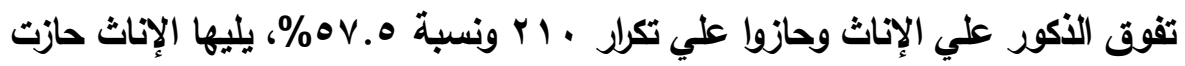

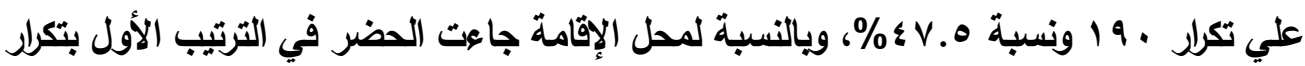

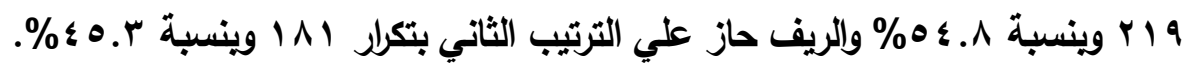


ب- بحيفة الاستبيان.

؛ - مقياس قلق الامتحان لسارسون

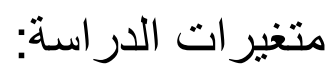

1- متغير مستقل: تعرض الطلاب لأخبار الاتتحار علي مواقع التواصل الاجتماعي.

$$
\text { r - r - r - متغير تابع: قلق الامتحان. }
$$

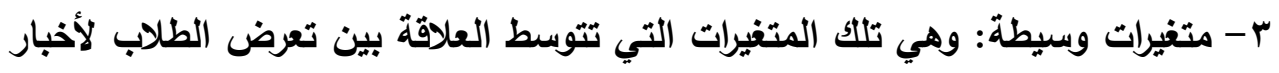

$$
\text { اجر اءات الصدق وات الثبات: الاتحان ( النوع - منطقة السكن ). }
$$

إجراءات ثبات الاستبيان: ويقصد به ثبات النتائج التي تفرزها أداة القياس، وقد استخدم

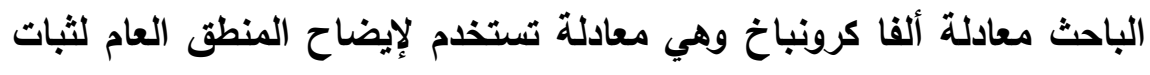

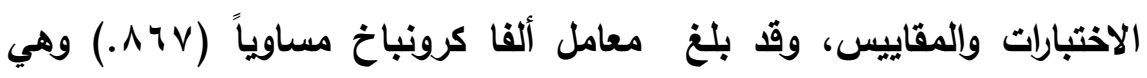

\section{درجة تؤكد تمتع الاستبيان بدرجة ثبات مناسبة.}

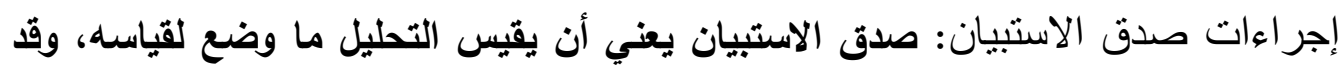

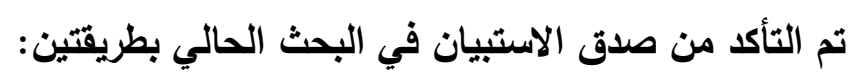

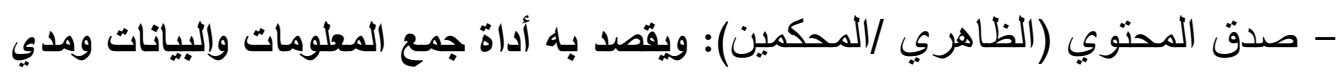

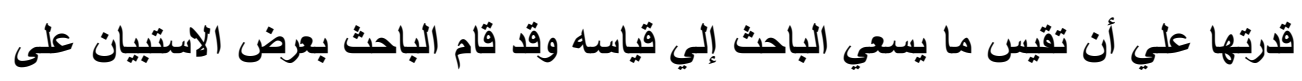

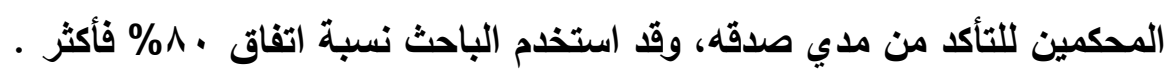

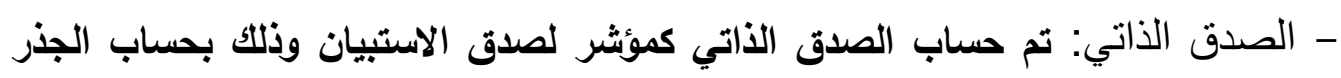

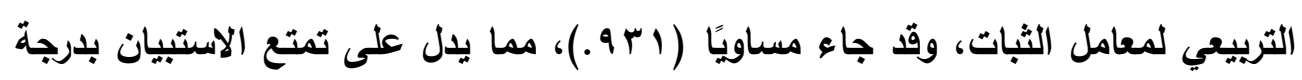

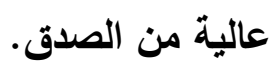


المعرض طلاب الثانوية العامة لأخبار انتحار الطلاب علي مواقع التواصل الاجتماعي للتوصل إلى نتائج الاراسة تم إجراء التحليل الإحصائي للبيانات الباحث واستخدم البرنامج الإحصائيSPSS وعدداً من الأدوات شملت ما يلي:

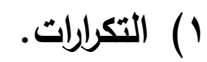

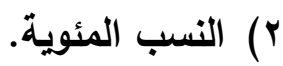

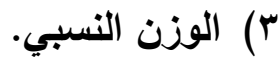
؛) معامل ارتباط بيرسون لمعرفة العلاقة بين المتغيرات بعضها ببعض.

نتائج البحث و تفسير ها: جدول (r)

يوضح درجة متابعة أفراد العينة لمواقع التواصل الاجتماعي حسب منطقة السكن

\begin{tabular}{|c|c|c|c|c|c|c|}
\hline \multirow{2}{*}{\multicolumn{2}{|c|}{ الإجمالي }} & \multicolumn{4}{|c|}{ العينة } & \multirow{3}{*}{ البدائل } \\
\hline & & \multicolumn{2}{|c|}{ ريف } & \multicolumn{2}{|c|}{ حضر } & \\
\hline المئويبة & التكرار & $\%$ & ك & $\%$ & ك5 & \\
\hline$\varepsilon V . Y_{0}$ & 119 & $\leqslant V . \leqslant q$ & $1 . \varepsilon$ & 27.97 & 10 & دائمًا \\
\hline rq. ro & $10 \mathrm{~V}$ & $\varepsilon Y_{.} \cdot 1$ & $q r$ & 10.91 & 70 & أحيانًا \\
\hline 14.0 & $0 \leqslant$ & $1 . .0$. & $r \mu$ & $1 \mathrm{~V} .1 \mathrm{~T}$ & r & نادرًا \\
\hline $1 \ldots$ & $\varepsilon \ldots$ & $1 \ldots$ & Y19 & $1 \ldots$ & 111 & الإجمالي \\
\hline
\end{tabular}

يتضح من الجدول السابق ما يلي:

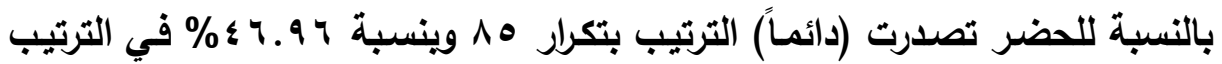

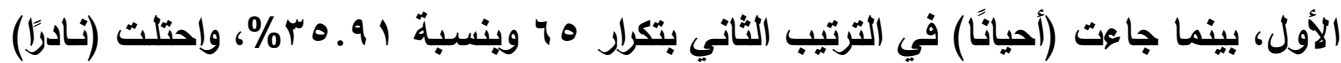

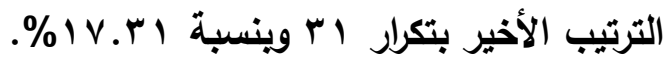
وأيضاً بنفس الترتيب السابق جاء التعرض (دائماً) في الترتيب الأول للريف بتكرار

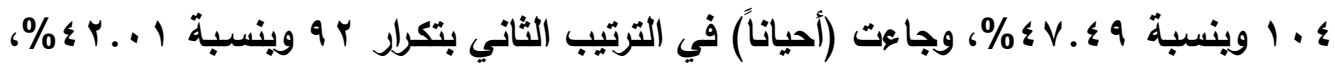

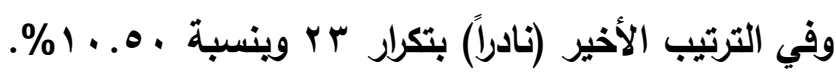
يري الباحث حصول متابعة أفراد العينة لمواقع التواصل الاجتماعي بصفة دائمـة علي هلي الترتيب الأول إلي أن هذه المواقع تقدم كل ما هو جليد، وانتشـار أجهزة المحمول التي تعمل بالأندرويد وتسهل الدخول علي أي موقع من مواقع التواصل الاجتماعي.

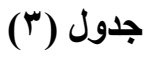


تعرض طلاب الثانوية العامة لأخبار انتحار الطلاب علي مواقع التواصل الاجتماعي .

يوضح درجة متابعة أفراد العينة لمواقع التواصل الاجتمـاعي حسب (النوع)

\begin{tabular}{|c|c|c|c|c|c|c|}
\hline \multirow{2}{*}{\multicolumn{2}{|c|}{ الإجمالي }} & \multicolumn{4}{|c|}{ العينة } & \multirow{3}{*}{ البدائل } \\
\hline & & \multicolumn{2}{|c|}{ إناث } & \multicolumn{2}{|c|}{ ذكور } & \\
\hline المئوية & التكرار & $\%$ & 5) & $\%$ & ك & \\
\hline$\varepsilon V . Y O$ & 119 & $\& 1.0$ & $\mathrm{V \Lambda}$ & OY.AY & 111 & دائمًا \\
\hline rq.Yo & $10 \mathrm{~V}$ & $\varepsilon$ & $V 7$ & $r \wedge . \diamond V$ & $\wedge 1$ & أحيانًا \\
\hline 11.0 & $0\}$ & 11.90 & ry & $\Lambda . \diamond \vee$ & 11 & نادرًا \\
\hline $1 \ldots$ & $\varepsilon \ldots$ & $1 \ldots$ & 19. & $1 \ldots$ & YI. & الإجمالي \\
\hline
\end{tabular}

يتضح من الجدول السابق ما يلي:

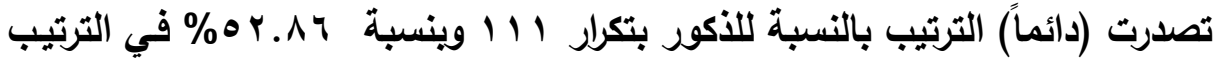
الأول، وجاءت (أحيانًا) في الترتيب الثاني بتكرار ا

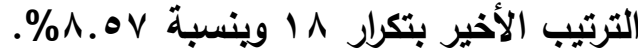
ويالتسبة للإنـاث جاء أيضـاً التعرض (دائمـاً) في الترتيب الأول بتكرار VA وينسبة

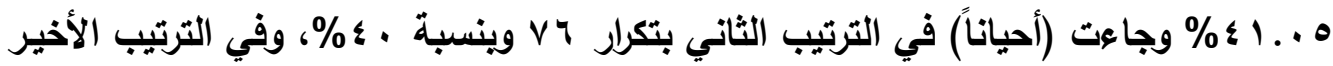

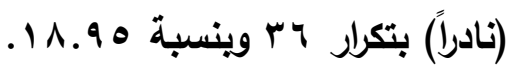
يري الباحث حصول متابعة أفراد العينة لمواقع التواصل الاجتماعي بصفة دائمـة علي الترتيب الأول بالنسبة للذكور والإنـاث لأن مواقع التواصل الاجتمـاعي أصبحث جزعاً لا يتجزأ من حياة الطلاب من الجنسين علي حد سواء 
تعرض طلاب الثانوية العامة لأخبار انتحار الطلاب علي مواقع التواصل الاجتماعي

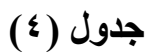

يوضح أسباب متابعة مواقع التواصل الاجتماعي حسب (منطقة السكن)

\begin{tabular}{|c|c|c|c|c|c|c|}
\hline \multirow{2}{*}{\multicolumn{2}{|c|}{ الإجمالي }} & \multicolumn{4}{|c|}{ العينة } & \multirow{3}{*}{ البدائل } \\
\hline & & \multicolumn{2}{|c|}{ ريف } & \multicolumn{2}{|c|}{ حضر } & \\
\hline المئوية & التكرار & $\%$ & ك & $\%$ & ك5 & \\
\hline 11.89 & $11 \mathrm{~V}$ & $r \wedge . \vee V$ & $4 \pi$ & $r q . \wedge r$ & $0 \leqslant$ & الخاصرة بالدراسة أولات \\
\hline$r \cdot .7 r$ & $r \cdot 1$ & $0 \leqslant . \vee q$ & ir. & $\varepsilon \varepsilon . \vee 0$ & 11 & المعلومات علي \\
\hline $1 . .71$ & 1.7 & $r . . \Delta q$ & IV & $Y 1.00$ & rq & فوريع الأحداث بشكل \\
\hline$r r . \cdot A$ & rpq & $7 . . Y V$ & Irr & $\Delta r . \Delta q$ & $9 V$ & اللتسراغية وقضاء وقت \\
\hline $0 . \leqslant \varepsilon$ & $0 \leqslant$ & $1 . .0$ & rY & $1 V .71$ & rr & وجرهات النظر مختلف \\
\hline $7 . r 0$ & $4 r$ & 10.04 & $r \varepsilon$ & $10 . \leqslant V$ & $r \wedge$ & التفاعل مع الأحداث من \\
\hline $1 Y . \cdot 9$ & Ir. & $\begin{array}{c}r r . v \\
q\end{array}$ & $V \varepsilon$ & $\begin{array}{c}r 0 . \varepsilon \\
1\end{array}$ & $\leq 7$ & أخري التعرف علي ثقافات \\
\hline 11.89 & $11 r$ & $\begin{array}{l}r o .0 \\
V\end{array}$ & 07 & $\begin{array}{c}r \cdot .9 \\
\varepsilon\end{array}$ & 07 & جلكوين صداقات \\
\hline
\end{tabular}

يتضح من الجدول السابق ما يلي:

9V تصدرث عبـارة (للتسلية وقضـاء وقت الفـراغ) الترتيب بالنسبة للحضـر بتكرار

وينسبة 9ه. هo\% وفي الترتيب الأول كأهم سبب لمتابعة مواقع التواصل الاجتمـاعي، بينما جاءت (للحصول علي المعلومات) في الترتيب الثاني بتكرار 1 ه وينسبة ه •. ؛ ؛ \%، واحتلت

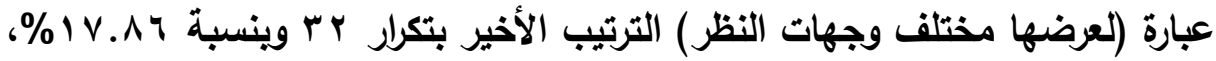
ويالنسبة للريف أيضاً حازت عبارة (للتسلية وقضاء وقت الفراغ) علي الترتيب الأول

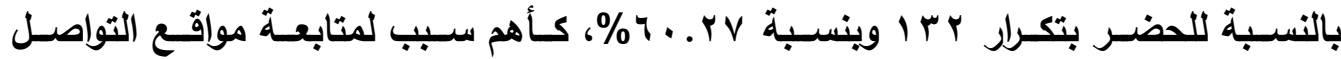
الاجتمـاعي، وجـاءت (للحصـول علـي المعلومـات) في الترتيب الثاني بتكرار • r ا وينسبة

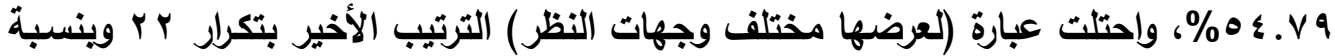


ويري الباحث حصول العبارة (للتسلية وقضاء وقت الفراغ) علي الترتيب الأول لأن مواقع التواصل الاجتمـاعي بها وسـائل تسلية من خـلال التفاعل مـع الأصدقاء عبر الدردشـة والألعاب الأكترونية المختلفة.

جذول (0)

يوضح عدد سنوات استخدام مواقع التواصل الاجتماعي

\begin{tabular}{|c|c|c|c|c|c|c|}
\hline \multirow{2}{*}{\multicolumn{2}{|c|}{ الإجمالي }} & \multicolumn{4}{|c|}{ العينة } & \multirow{3}{*}{ البدائل } \\
\hline & & \multicolumn{2}{|c|}{ ريف } & \multicolumn{2}{|c|}{ حضر } & \\
\hline المئوية & التكرار & $\%$ & ك5 & $\%$ & ك5 & \\
\hline YY.YO & $\wedge q$ & $r r_{. \wedge \Lambda}$ & 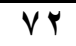 & 9.49 & IV & منذ أقلّ من عام \\
\hline 11.Yo & $v^{r}$ & $11 . \leqslant r$ & ro & Y $7.0 Y$ & $\leqslant \Lambda$ & من عام إلى عامين \\
\hline $1 V .0$ & $v$. & 19.74 & $\varepsilon r$ & $1 \leq .94$ & YV & منذ r إلي ء أعوام \\
\hline YI.Yo & 10 & $1 \leq .71$ & $r r$ & $r q . r \wedge$ & or & من ؛ إلي ه أعوام \\
\hline$r \cdot . V 0$ & $\Lambda T$ & Y 1.57 & $\varepsilon V$ & 19.19 & mq & أكثر من ذلك \\
\hline $1 \ldots$ & $\varepsilon \ldots$ & $1 \ldots$ & P19 & $1 \ldots$ & 111 & الإجمالى \\
\hline
\end{tabular}

يتضح من الجدول السابق ما يلي:أن أفراد العينة يستخدمون مواقع التواصل الاجتماعي (منذ ؛

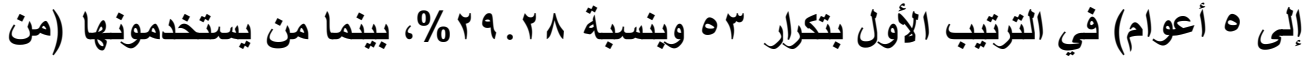

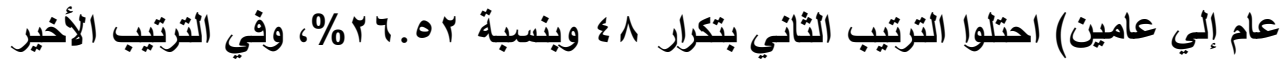

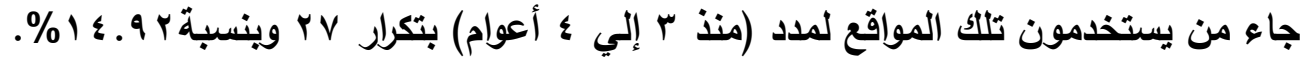

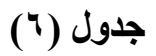

يوضح درجة الاهتمام بمتابعة المواقع يوميًا

\begin{tabular}{|c|c|c|c|c|c|c|}
\hline \multirow{2}{*}{\multicolumn{2}{|c|}{ الإجمالي }} & \multicolumn{4}{|c|}{ العينة } & \multirow{3}{*}{ البدائل } \\
\hline & & \multicolumn{2}{|c|}{ ريف } & \multicolumn{2}{|c|}{ حضر } & \\
\hline المئوية & الت التكرار & $\%$ & ك5 & $\%$ & ك5 & \\
\hline$\varepsilon Y . Y_{0}$ & 179 & 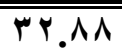 & VY & 04.09 & $9 V$ & مرة واحدة يومياً \\
\hline 9.0. & rs & 11.24 & ro & $\vee .1 \wedge$ & ir & عدة مرات يومياً \\
\hline 11.40 & $V r$ & 19.74 & $\varepsilon r$ & $17.0 \mathrm{~V}$ & $r \cdot$ & عدة مرات أسبوعياً \\
\hline Ir... & $\varepsilon \wedge$ & $1 \varepsilon .71$ & rr & $\wedge . \wedge \varepsilon$ & 17 & عدة مرات شهرياً \\
\hline $19 . \ldots$ & V7 & Y1. 19 & $\varepsilon V$ & 17.4 & rq & لا أستطيع التحديد \\
\hline $1 \ldots$ & $\{\ldots$ & $1 \ldots$ & Y 19 & $1 \ldots$ & $|\wedge|$ & الإجمالي \\
\hline
\end{tabular}

يتضــح مـن الجـدول الســابق: أن درجـة اهتمــام المبــوثين بمتابعـة مواقِع التواصـل

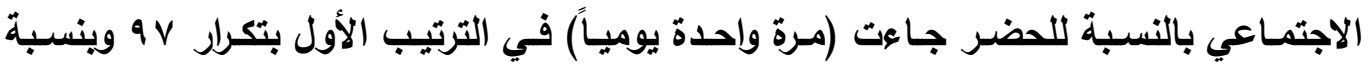




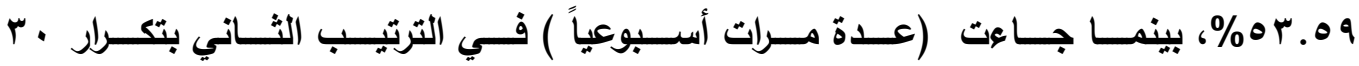
وينسبة Vه. 1 \% \%، والترتيب الأخير كان من نصيب أفراد العينة الذي يتابعون المواقع (عدة

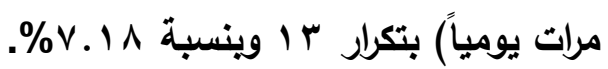

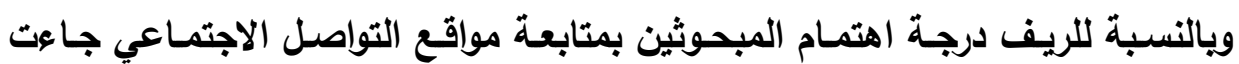

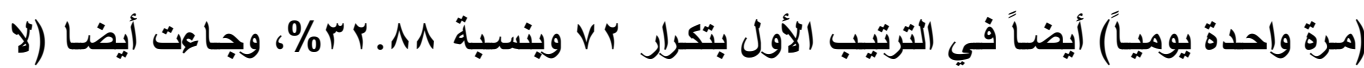

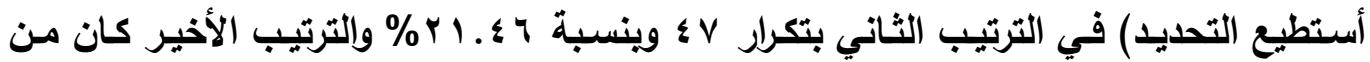

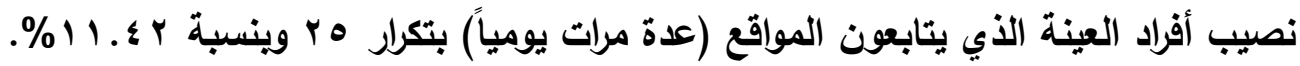

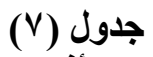

يوضح الوقت الذي يقضيه أفر اد العينة في متابعة المواقع

\begin{tabular}{|c|c|c|c|c|c|c|}
\hline \multirow{2}{*}{\multicolumn{2}{|c|}{ الإجمالي }} & \multicolumn{4}{|c|}{ العينة } & \multirow{3}{*}{ البدائل } \\
\hline & & \multicolumn{2}{|c|}{ ريف } & \multicolumn{2}{|c|}{ 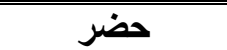 } & \\
\hline المئويبة & الت التكرار & $\%$ & ك5 & $\%$ & ك5 & \\
\hline 19.0. & $\mathrm{V \Lambda}$ & 10.91 & ro & YT.VO & $\varepsilon r$ & أقّل من نصف ساعة في كل مرة \\
\hline YV.YO & 1.9 & YY.rV & $\leqslant 9$ & ru.ls & 7. & أقّل من سـاعة \\
\hline $1 V_{.} \ldots$ & 71 & IV.ro & rA & $17.0 \mathrm{~V}$ & $r$. & أقل من ساعتين \\
\hline $1 V .0$. & $v \cdot$ & YI. 57 & $\leqslant V$ & IY.VI & rr & أكثر من ذلك \\
\hline 11.20 & Vo & YY.AT & 0. & $\mid r . \Lambda 1$ & ro & لا أستطيع التحديا \\
\hline $1 \ldots$ & $\varepsilon \ldots$ & $1 \ldots$ & Y19 & $1 \ldots$ & 111 & الإجمالي \\
\hline
\end{tabular}

يتضح من الجدول السابق أن: بالنسبة للوقت الذي يقضيه المبحوثين طلاب الحضر في متابعة مواقِع التواصل الاجتمـاعي جـاء ممثنًا في عبـارة (أقل من سـاعة) في الترتيب الأول

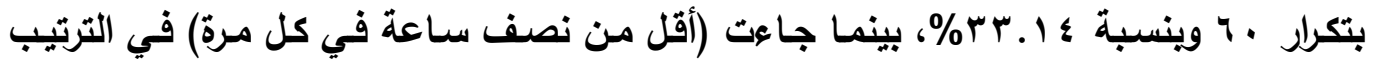

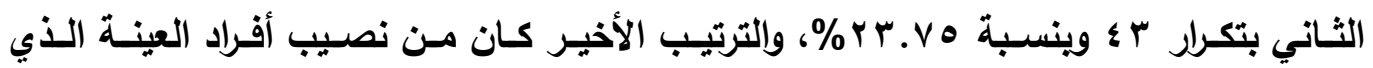

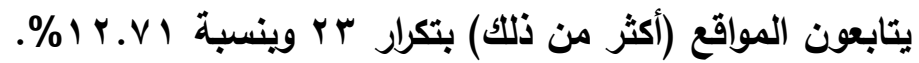

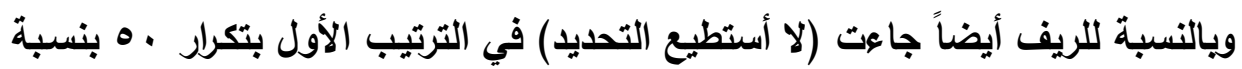

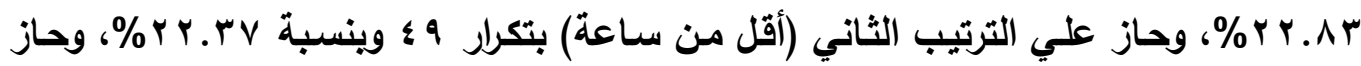

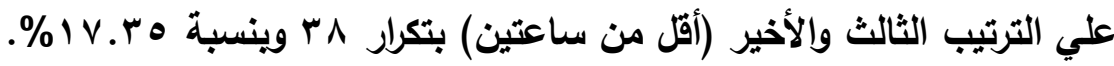

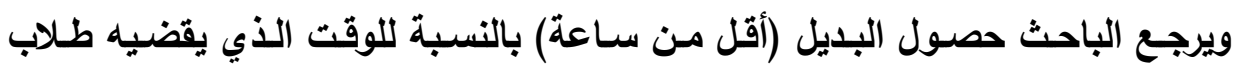

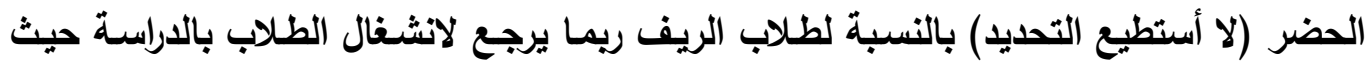
تتسم طبيعة دراسة الثانوية العامة بالصعوية. 
تعرض طلاب الثانوية العامة لأخبار انتحار الطلاب علي مواقع التواصل الاجتماعي ...

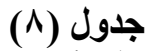

يوضح درجة الحرص على متابعة الأخبار علي مواقع التواصل الاجتماعي

\begin{tabular}{|c|c|c|c|c|c|c|c|}
\hline \multicolumn{7}{|c|}{ العينة الكلية } & \\
\hline \multirow{2}{*}{ الترتي } & \multirow{2}{*}{ المئويبة } & \multirow{2}{*}{ النسبي } & \multicolumn{4}{|c|}{ التكرار } & \\
\hline & & & لا أتابعها & ضعيفة & متوسطة & كبيرة & \\
\hline$r$ & $\begin{array}{c}7,7 \\
\%\end{array}$ & IFYT & $\leqslant 7$ & 0 . & IrA & $\mid V \varepsilon$ & فيس بوك \\
\hline$\varepsilon$ & $\begin{array}{c}\varepsilon \leqslant, q \\
\%\end{array}$ & 819 & YIV & vo & VY & & تويتر \\
\hline 1 & $\begin{array}{r}\Lambda \cdot, r \\
\%\end{array}$ & I rAY & rA & 01 & Irr & 197 & يوتيوب \\
\hline$r$ & $\begin{array}{l}V V, 1 \\
\%\end{array}$ & ITKE & 0 . & 01 & 1.7 & 191 & واتس آب \\
\hline
\end{tabular}

يتضح من الجدول السابق ما يلي: تصدر موقع (يوتيوب) مواقع التواصل الاجتمـاعي

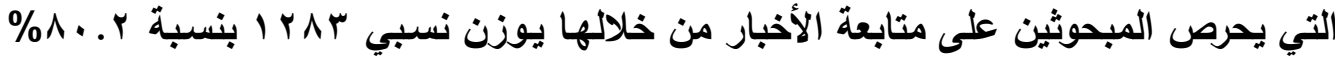

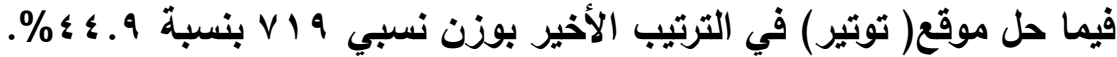
ويري الباحث أن حصول يوتيوب علي الترتيب الأول هي نتيجة منطقية، لأن موقع يوتيوب يزداد انتشاره واستخدامه بصورة كبيرة وذلك لأنه أحد أبرز منصـات مشـاهدة الفيديو

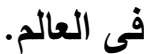

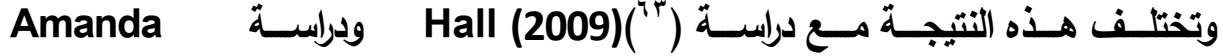

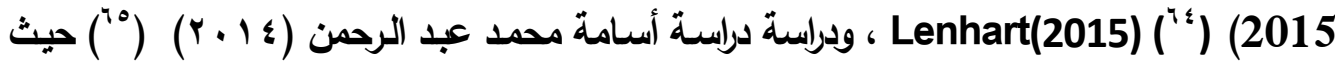
جاء الفيس بوك في مقدمة هذه المواقع من حيث الاستخدام

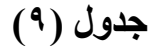

يوضح درجة الثقة في الأخبار التي تعرضها مواقع التواصل الاجتماعي

\begin{tabular}{|c|c|c|c|c|c|c|}
\hline \multicolumn{6}{|c|}{ العينة } & \\
\hline \multirow[b]{2}{*}{ تيب } & \multirow{2}{*}{ المئوية } & \multirow[b]{2}{*}{ النسبي } & \multicolumn{3}{|c|}{ التكرار } & \\
\hline & & & لا لأثقا & أثق فيها إلي & أثق بلرجة & \\
\hline$r$ & $\% 70,1$ & V^I & $9 V$ & Y19 & $\overline{\Lambda Y}$ & فيس بوك \\
\hline$\varepsilon$ & $\% \otimes \wedge, 0$ & $V \cdot r$ & 179 & 17. & Vr & تويتر \\
\hline$r$ & $\%$ TV, 9 & 110 & 90 & 119 & $11 \varepsilon$ & يوتيوب \\
\hline 1 & $\% \vee v, r$ & 100 & 9. & 109 & $1 \leq 9$ & واتس آب \\
\hline
\end{tabular}


يتضح من الجدول السابق ما يالي:تصدر موقع (واتس آب) مواقع التواصل الاجتماعي

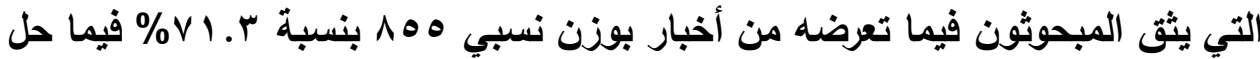

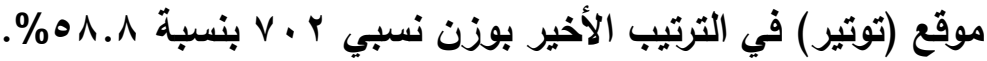
جدول (·) (1)

التعرض لأخبار الاتتحار حسب نوع (العينة (ذكور - اناث)

\begin{tabular}{|c|c|c|c|c|c|c|}
\hline \multirow{2}{*}{\multicolumn{2}{|c|}{ الإجمالي }} & \multicolumn{4}{|c|}{ العينة } & \multirow{3}{*}{ 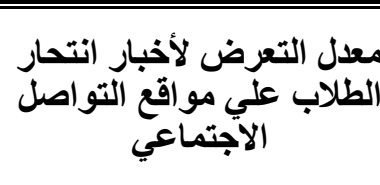 } \\
\hline & & \multicolumn{2}{|c|}{ إناث } & \multicolumn{2}{|c|}{ ذكور } & \\
\hline المئوية & التكرار & $\%$ & ك & $\%$ & ك & \\
\hline$\overline{\Lambda \Lambda . Y^{\circ}}$ & TYI & $\Lambda$. & 104 & $\Lambda \cdot . \leqslant V$ & 179 & نعم \\
\hline 19.80 & $\sqrt{99}$ & Y. & $\overline{r \Lambda}$ & 19.04 & \&1 & $\bar{y}$ \\
\hline $1 \cdots$ & $\varepsilon \ldots$ & $1 \cdots$ & 19. & $1 \ldots$ & YI. & الإجمالى \\
\hline
\end{tabular}

يتضح من الجدول السابق أن: الأكور الأين يتعرضون لأخبار الاتتحار علي مواقع

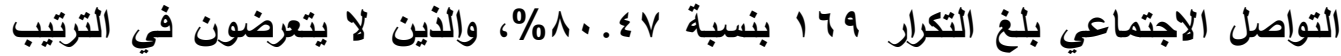

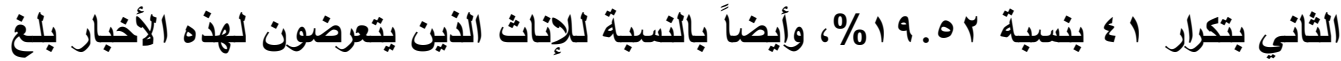

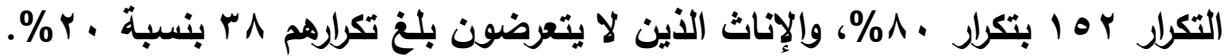
ويري الباحث أن تفسير حصول التعرض لأخبار الانتحار علي مواقع التواصل علي هذه النسب المرتفعة للأكور والإناث يرجع إلي أن هذه النوعية من الأخبار علي الأهمية بالنسبة

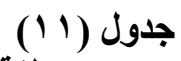

لارتباطها بمستقبلهم التعليمي وإلمهني.

التعرض لأخبار الانتحار حسب منظقة السكن (حضر - ريف)

\begin{tabular}{|c|c|c|c|c|c|c|}
\hline \multirow{2}{*}{\multicolumn{2}{|c|}{ الإجمالي }} & \multicolumn{4}{|c|}{ العينة } & \multirow{3}{*}{ 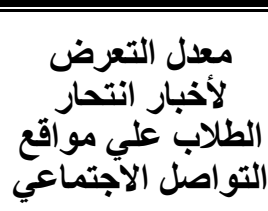 } \\
\hline & & \multicolumn{2}{|c|}{ ريف } & \multicolumn{2}{|c|}{ حضر } & \\
\hline المئويبة & التكرار & $\%$ & ك & $\%$ & ك & \\
\hline$\overline{\Lambda \Lambda . Y \Delta}$ & TYT & 189.99 & $T V \varepsilon$ & 11.79 & $T \leqslant V$ & نعم \\
\hline 19.10 & 189 & $r \cdot .9$. & $\varepsilon 7$ & $I \Lambda . \mu r$ & $r \mu$ & $y$ \\
\hline $1 \ldots$ & $\xi \ldots$ & $1 \ldots$ & Yr. & $1 \ldots$ & 11. & الإجمالي \\
\hline
\end{tabular}

يتضح من الجدول السابق أن: طلاب الحضر الذين يتعرضون لأخبار الانتحار علي

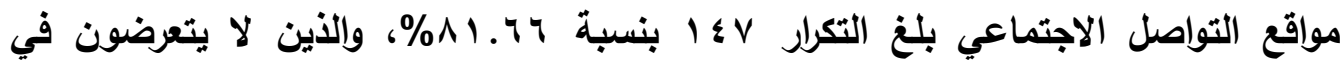

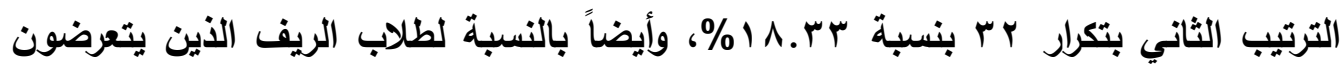




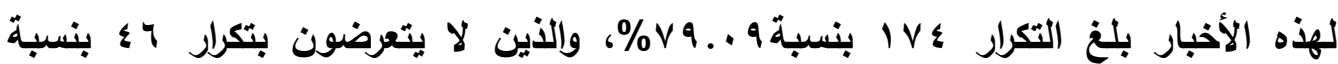
.\% r..q.

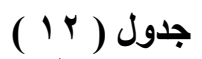

رأي المبحوثين عن أسباب وصول الطالب للانتحار حسب نوع العينة.

\begin{tabular}{|c|c|c|c|c|c|c|}
\hline \multirow{2}{*}{\multicolumn{2}{|c|}{ الإجمالي }} & \multicolumn{4}{|c|}{ العينذة } & \multirow{3}{*}{ آراء الطلاب } \\
\hline & & \multicolumn{2}{|c|}{ إناثً } & \multicolumn{2}{|c|}{ ل ذكور } & \\
\hline المئوية & التكرار & $\%$ & ك & $\%$ & ك5 & \\
\hline 9.97 & Tr & 1.7. & $1 \pi$ & $11.1 \mathrm{~V}$ & 19 & صعوبة المناهج \\
\hline r & $1 \cdot v$ & $\varepsilon 1.0$ & ir & $r q . \leqslant V$ & $\leq 0$ & الطلاب لتحقيق اولياء الامور علثي أعلى \\
\hline$\leqslant 1 . v 1$ & Ir & $r q . \vee r$ & 7. & $\varepsilon r .0 r$ & $V \varepsilon$ & 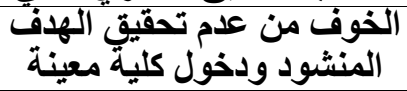 \\
\hline 9.97 & rr & ^.7. & ir & $11.1 \mathrm{~V}$ & 19 & درجات القبول المطلوبنيات من القبات \\
\hline$\varepsilon .91$ & 17 & 1.91 & $r$ & $\vee . T \varepsilon$ & ir & التوريقلة التي تعرضلاب المنتحرين مواقع \\
\hline $1 \cdots$ & MrI & $1 \cdots$ & 101 & $1 \cdots$ & IV. & الإجمالي \\
\hline
\end{tabular}

يتضح من الجدول السابق أن: بالنسبة للأكور جاء(الخوف من عدم تحقيق الهدف

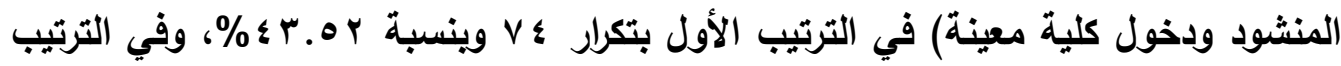

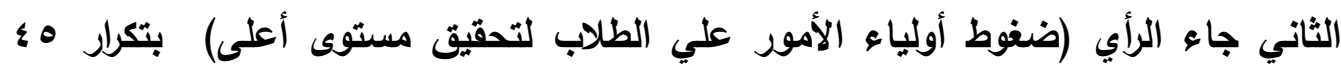

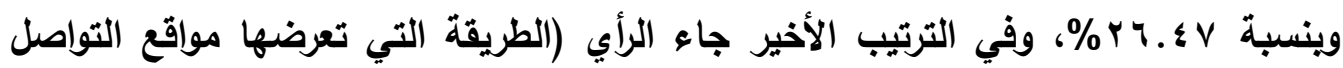

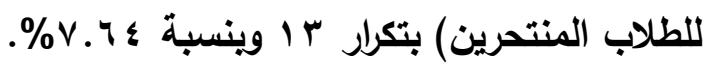
ويالنسبة للإناث تصدر الرأي (ضغوط أولياء الأمور علي الطلاب لتحقيق مستوي

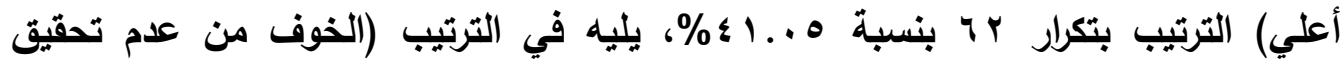

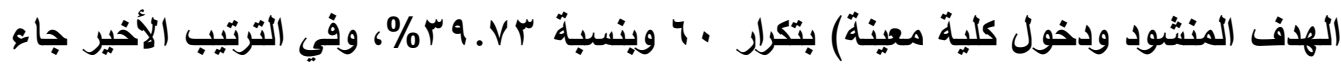

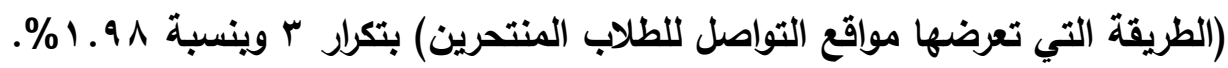
ويرى الباحث أن تبادل الرأيين (الخوف من عدم تحقيق الهـف المنشود ودخول كلية معينة) والرأى (ضغوط أولياء الأمور علي الطلاب لتحقيق مستوي أعلي) الترتيب الأول والثاني بالتبادل يرجع لارتفاع الحد الأدنى للقبول بالكليات والذي يرتبط بالارتفاع في أعداد الطلاب كل عام عن العام الأي يسبقه مما يضعف من فرص دخول الكلية التي ينشدها الطالب، ونظراً 
تعرض طلاب الثانوية العامة لأخبار انتحار الطلاب علي مواقع التواصل الاجتماعي .

لأن بعض أولياء الأمور يضغطون علي الطلاب لتحقيق هدفهم المنشود مما يجعل هذا الحلم يصبح كابوس وشبح بـهد الطلاب ويؤدي بهم إلي الانتحار.

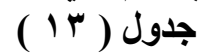

رأي المبحوثين عن أسباب وصول الطالب للانتحار حسب منطقة السكن

\begin{tabular}{|c|c|c|c|c|c|c|}
\hline \multirow{2}{*}{\multicolumn{2}{|c|}{ الإجمالي }} & \multicolumn{4}{|c|}{ العيذة } & \multirow{3}{*}{ رأي الطلاب } \\
\hline & & \multicolumn{2}{|c|}{ ريف } & \multicolumn{2}{|c|}{ حضر } & \\
\hline النسبة المئوية & التكرار & $\%$ & ك5 & $\%$ & ك5 & \\
\hline 9.97 & rY & 14.20 & $r r$ & $7 . \cdots$ & 9 & صعوبة المناهج \\
\hline Tr.rT & $1 \cdot v$ & YY.YY & rᄉ & $\leq \uparrow_{.}$. & 79 & الطلاب لتحقيقّ أوليا \\
\hline$\leq 1 . V \leq$ & $1 T \varepsilon$ & $\leqslant V . r q$ & $\wedge 1$ & ro.rr & or & الخوفت من عدم تحقيق الهونة كعنة \\
\hline 9.97 & rr & 9.40 & 17 & $1 \cdot .74$ & 17 & ارتفاع الحد المطلوب من باتليات \\
\hline$\varepsilon .91$ & 17 & V.. & ir & r... & $r$ & 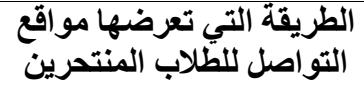 \\
\hline $1 \ldots$ & MY & $1 \ldots$ & 121 & $1 \ldots$ & 10. & الإجمالي \\
\hline
\end{tabular}

يتضح من الجدول السابق أن: بالنسبة للحضر (ضغوط أولياء الأمور علي الطلاب لتحقيق مستوي أعلي) حازت علي الترتيب الأول بتكرار 97 وينسبة . . . \؛ \% وفي الترتيب الثاني جاء الرأي (الخوف من عدم تحقيق الهوف المنشود ودخول كلية معينة) بتكرار باري

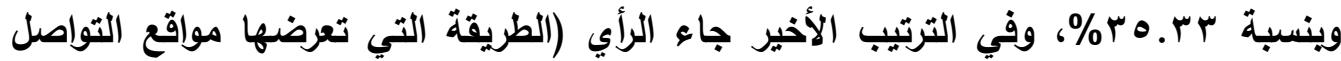
للطلاب المنتحرين) بتكرار r وينسبة . . . . ويالنسبة للريف تصدر الرأي (الخوف من عدم تحقيق الهـف المنشود ودخول كلية

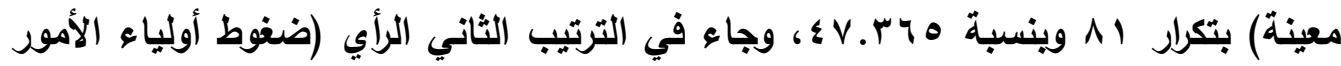

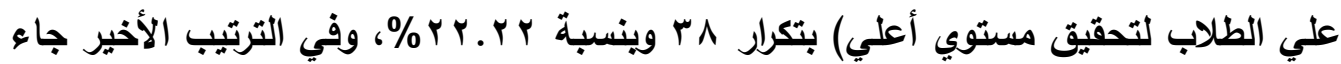

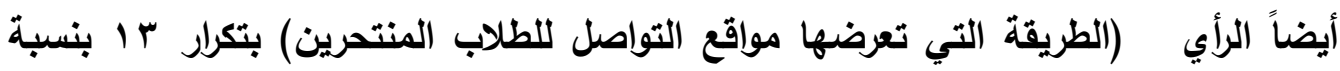


تعرض طلاب الثانوية العامة لأخبار انتحار الطلاب علي مواقع التواصل الاجتماعي

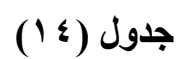

مدي الثعور بالقلق عند التعرض لأخبار علي مواقع التواصل (حسب النوع)

\begin{tabular}{|c|c|c|c|c|c|c|}
\hline \multirow{2}{*}{\multicolumn{2}{|c|}{ الإجمالي }} & \multicolumn{4}{|c|}{ العينة } & \multirow{3}{*}{ البدائل } \\
\hline & & \multicolumn{2}{|c|}{ إناث } & \multicolumn{2}{|c|}{ ذكور } & \\
\hline المئوية & التكرار & $\%$ & ك & $\%$ & ك5 & \\
\hline$v \cdot .1 T$ & $r \mu$. & $\Lambda \varepsilon . \vee V$ & ITr & OV.rI & 91 & نعم \\
\hline YQ.Av & 91 & 10.94 & Yo & $\& Y .79$ & $V r$ & $y$ \\
\hline $1 \ldots$ & ris & $1 \ldots$ & $10 \mathrm{~V}$ & $1 \ldots$ & $1 \mathrm{VI}$ & الإجمالي \\
\hline
\end{tabular}

يتضح من الجدول السابق أن: الطلاب الذكور الذين يشعرون بالقلق عند التعرض

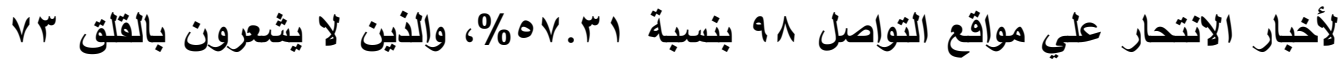

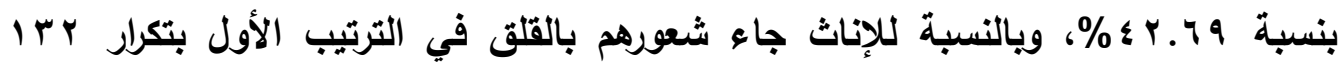

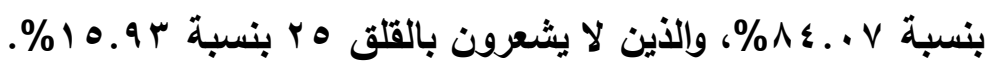

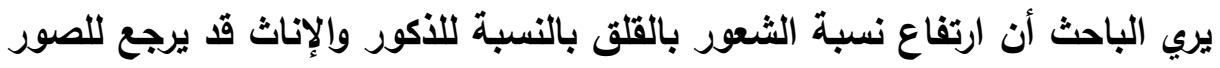

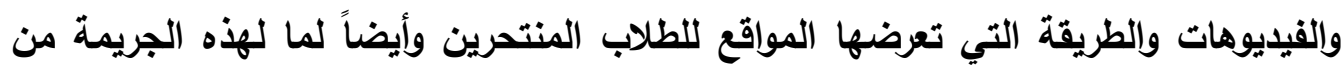
مأساوية وتأثثر علي نفس من يقرأ ويتابع هذه الأخبار .

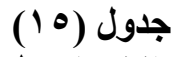

مدى الثعور بالقلق عند التعرض لأخبار الاتتحار علي مواقع التواصل (حسب منطقة السكن)

\begin{tabular}{|c|c|c|c|c|c|c|}
\hline \multirow{2}{*}{\multicolumn{2}{|c|}{ الإجمالي }} & \multicolumn{4}{|c|}{ العينة } & \multirow{3}{*}{ البدائل } \\
\hline & & \multicolumn{2}{|c|}{ ريف } & \multicolumn{2}{|c|}{ حضر } & \\
\hline المئوية & التكرار & $\%$ & ك5 & $\%$ & ك5 & \\
\hline$v \cdot .1 T$ & rT. & $74 . \wedge 7$ & 119 & $V \varepsilon$ & 111 & نعم \\
\hline rq.AV & 91 & rr.Is & 09 & rq & $r q$ & $y$ \\
\hline $1 \ldots$ & TYA & $1 \ldots$ & $I V \Lambda$ & $1 \ldots$ & 10. & الإجمالي \\
\hline
\end{tabular}

يتضح من الجدول السابق أن: طلاب الحضر الذين يشعرون بالقلق عند التعرض

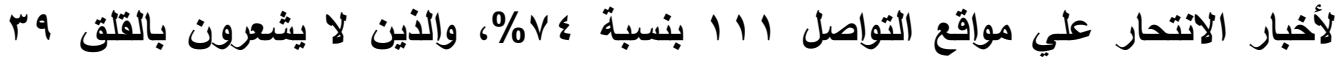
بنسبة צr\%، ويالنسبة للريف جاء شعورهم بالقلق في الترتيب الأول بتكرار 911 ب بنسبة

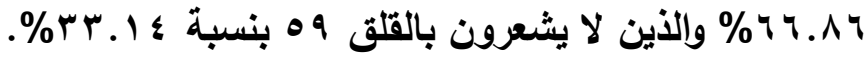


تعرض طلاب الثانوية العامة لأخبار انتحار الطلاب علي مواقع التواصل الاجتماعي ...

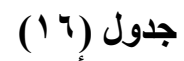

أسباب الثعور بالقلق عند التعرض لأخبار الاتتحار علي مواقع التواصل

\begin{tabular}{|c|c|c|c|c|c|c|}
\hline \multirow{2}{*}{\multicolumn{2}{|c|}{ الإجمالي }} & \multicolumn{4}{|c|}{ العينة } & \multirow{3}{*}{ البدائل } \\
\hline & & \multicolumn{2}{|c|}{ ريف } & \multicolumn{2}{|c|}{ حضر } & \\
\hline المئوية & التكرار & $\%$ & ك5 & $\%$ & ك5 & \\
\hline $1 V .0 \leqslant$ & $\varepsilon$. & $\Lambda .0 \leqslant$ & 1. & $r V_{\cdot} \cdot r$ & r. & أعنداد الطلاب \\
\hline$\leqslant r . \wedge 0$ & $1 \ldots$ & $r \wedge . \leqslant 7$ & $\leq 0$ & $\leqslant 9.0 \leqslant$ & 00 & تلعزضلاب الميا المواتع التي \\
\hline$r \wedge . \Delta q$ & $\wedge \wedge$ & or.qq & Tr & $r r . \leqslant r$ & Y & الأخبار عرض هذه \\
\hline $1 \ldots$ & YYA & $1 \ldots$ & $11 \mathrm{~V}$ & $1 \ldots$ & 111 & الإجمالى \\
\hline
\end{tabular}

يتضح من الجدول السابق أن: بالنسبة لطلاب العضر تصدر السبب (الفيديوهات

التي تعرضها المواقع للطلاب المنتحرين) وحاز علي الترتيب الأول بتكرار هـ وينسبة

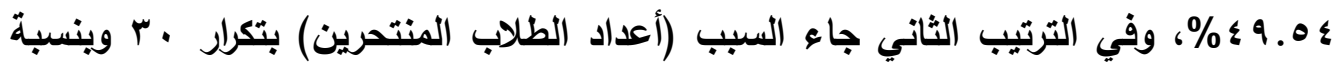

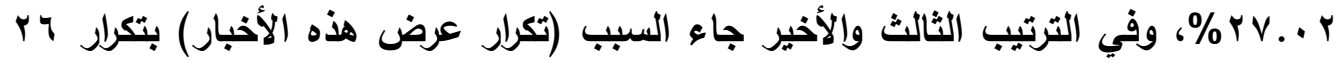

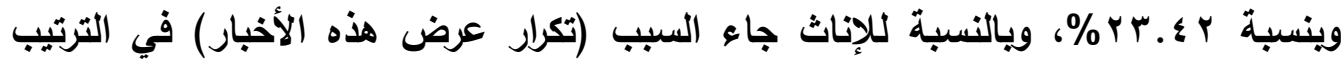

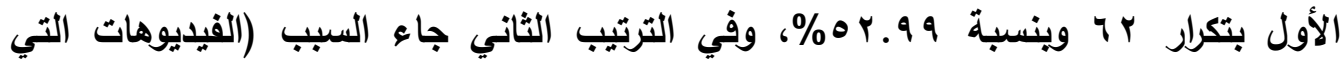

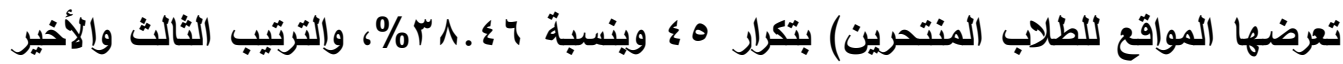

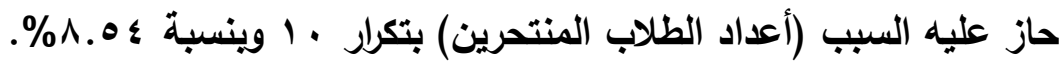

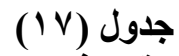

موقف المبحوثين تجاه الموقع الذي يعرض أخبار انتحار الطلاب

\begin{tabular}{|c|c|c|c|c|c|c|}
\hline \multirow{2}{*}{\multicolumn{2}{|c|}{ الإجمالي }} & \multicolumn{4}{|c|}{ العينة } & \multirow{3}{*}{ البدائل } \\
\hline & & \multicolumn{2}{|c|}{ ريف } & \multicolumn{2}{|c|}{ حضر } & \\
\hline المئوية & التكرار & $\%$ & ك & $\%$ & كs & \\
\hline 10.10 & Or & $11 . \% r$ & r. & ri.rr & $\overline{T r}$ & ألنفي إعجابي \\
\hline rv. 19 & Irr & Mr.OA & $0 \wedge$ & \& & $7 \varepsilon$ & وإبداء بتعليقاتي \\
\hline $1 . .9 \mathrm{~V}$ & $r q$ & $1 \leqslant .7$. & rq & 7.79 & 1. & أغير الموقع \\
\hline ro.9V & 111 & $\& 1.0 \mathrm{~V}$ & $V \varepsilon$ & rq.rr & $\varepsilon \varepsilon$ & لا أهتم \\
\hline $1 \ldots$ & TrA & $1 \ldots$ & $I V \wedge$ & $1 \ldots$ & 10. & الإجمالي \\
\hline
\end{tabular}


يتضح من الجدول السابق أن: موقف المبحوثين (أشارك بتعليقاتي وإبداء رأيي) علي

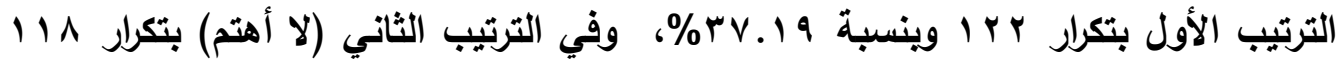

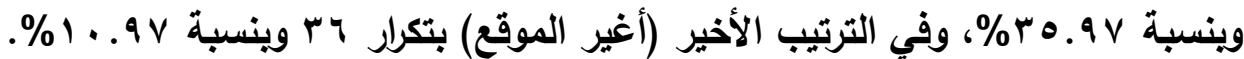

ويري الباحث حصول موقف المبحوثين (أثارك بتعليقاتي وإبداء رأيي) علي الترتيب

الأول، والموقف (أغير الموقع) علي الترتيب الأخير لما لهذه القضية من أهمية علي ساحة

الرأي العام ولما لها من أهمية خاصة بهؤلاء الطلاب ومستقبلهم الهئ

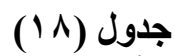

رد فعل المبحوثين عند التعرض لأخبار انتحار الطلاب علي مواقع التواصل

\begin{tabular}{|c|c|c|c|c|c|c|}
\hline \multirow{2}{*}{\multicolumn{2}{|c|}{ الإجمالي }} & \multicolumn{4}{|c|}{ العينة } & \multirow{3}{*}{ البدائل } \\
\hline & & \multicolumn{2}{|c|}{ ريف } & \multicolumn{2}{|c|}{ حضر } & \\
\hline المئويبة & 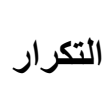 & $\%$ & ك & $\%$ & ك5 & \\
\hline$\leqslant 0 . \leqslant Y$ & $1 \leqslant 9$ & $\leqslant 1.1$ & 9. & Tr.T. & 09 & أنتحاور مع أصدقائي حولها \\
\hline 19.19 & $\varepsilon$ & 7.10 & 10 & $1 \% . \wedge 1$ & ro & أتحاور مع أساتذتي عنها \\
\hline $19 . \wedge 1$ & 70 & $\mid V . \Lambda 1$ & rq & $1 \varepsilon .47$ & Y & أتحاور مع أسرتي عنها \\
\hline YY.TO & $V \leqslant$ & 10.04 & $r \varepsilon$ & rY.1. & $\varepsilon$. & أتجاهلها تماماً " \\
\hline $1 \ldots$ & TrA & $\Lambda 1 . Y \Lambda$ & $I \vee \wedge$ & $\wedge Y . \wedge V$ & 10. & الإجمالي \\
\hline
\end{tabular}

يتضح من الجدول السابق: تصدر رد فعل المبحوثين (أتحاور مـع أصدقائي حولها)

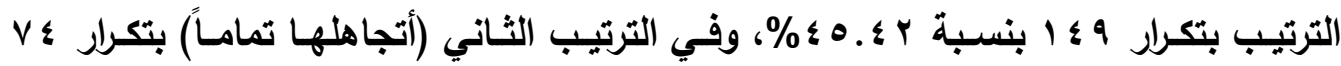

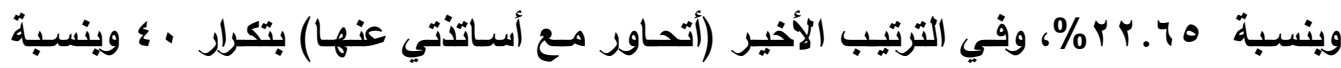

جدول (9 9 (1)

أسباب متابعة الطلاب لأخبار انتحار الطلاب علي مواقع التواصل

\begin{tabular}{|c|c|c|c|c|c|c|}
\hline \multirow{2}{*}{\multicolumn{2}{|c|}{ الإجمالي }} & \multicolumn{4}{|c|}{ العينة } & \multirow{3}{*}{ البدائل } \\
\hline & & \multicolumn{2}{|c|}{ ريف } & \multicolumn{2}{|c|}{ حضر } & \\
\hline المئوية & 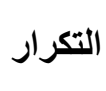 & $\%$ & ك & $\%$ & ك & \\
\hline 19.01 & $7 \varepsilon$ & $11 . r 4$ & $r$. & $r q . \mu r$ & $\leq \varepsilon$ & لأنها تمس مستقبلي \\
\hline$\leqslant \varepsilon .01$ & $1 \leq 7$ & $\varepsilon V . V \theta$ & 10 & $\varepsilon . .77$ & 71 & معرفة السبب ورائها \\
\hline YY.YI & A & Y^.70 & 01 & rT.rT & ro & حب الاستطلاع \\
\hline 9.10 & Tr & IY.ro & YY & 7.79 & 1. & قلقي من الامتحان \\
\hline $1 \cdots$ & rYA & $1 \cdots$ & $1 \vee \wedge$ & $1 \cdots$ & 10. & الإجمالي \\
\hline
\end{tabular}


يتضح من الجدول السابق: جاء سبب المتابعة (معرفة السبب ورائها) في الترتيب

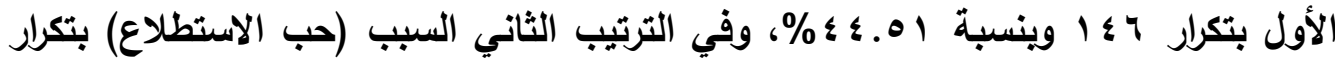

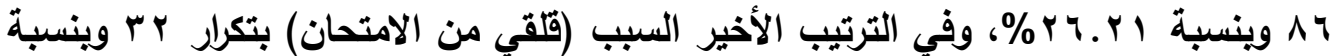
.\%9.v०

ويري الباحث حصول سبب المتابعة (معرفة السبب ورائها) علي الترتيب الأول يرجع إلي أن هذه الظاهزة أصبحت لافتة للنظر وكونت هاجس عند طلاب الثانوية العامة.

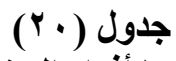

الصورة التي يكونها أفراد (العينة للطالب المنتحر

\begin{tabular}{|c|c|c|c|c|c|c|}
\hline \multirow{2}{*}{\multicolumn{2}{|c|}{ الإجمالي }} & \multicolumn{4}{|c|}{ العينة } & \multirow{3}{*}{ البدائل } \\
\hline & & \multicolumn{2}{|c|}{ ريف } & \multicolumn{2}{|c|}{ حضر } & \\
\hline المئوية النسبة & التكرار & $\%$ & ك5 & $\%$ & ك5 & \\
\hline 17.27 & $0 \leq$ & IY.Mo & YY & rI.rr & Tr & لم يجل من يساعده \\
\hline$Y 7 . \wedge Y$ & $\Lambda \wedge$ & $Y V .0 Y$ & $\leqslant 9$ & Y & pq & أجرم في حق نفسه \\
\hline $9.1 \leq$ & $r$ & $\wedge .9 \wedge$ & 17 & q.r & $1 \varepsilon$ & الطالد في تشتويله صورة \\
\hline$\sum V .07$ & 107 & $01.1 Y$ & 91 & $\varepsilon r . r r$ & 70 & لم يجد من يدعمه نفسياً \\
\hline $1 \cdots$ & TrA & $\Lambda 1 . Y \Lambda$ & $I V \Lambda$ & AY.AV & 10. & الإجمالي \\
\hline
\end{tabular}

يتضح من الجدول السابق: تصدرت (لا يجد من ياعمه نفسياً) الصور التي يكونها

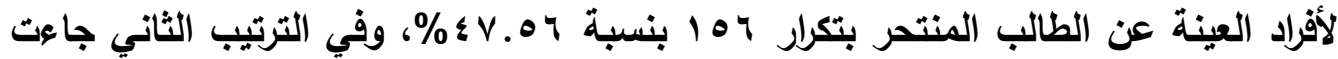

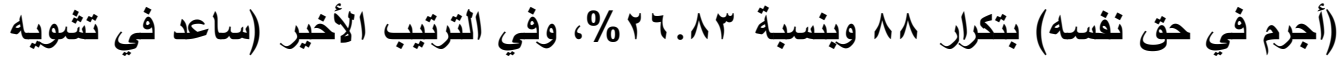

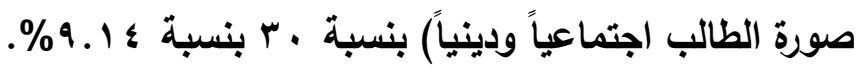
يري الباحث حصول الرأي (لم يجد من يدعمه نفسياً) علي الترتيب الأول يرجع لأهمية الدعم النفسي للطلاب في مرحلة الثانوية وعدم تعريضهم للضغوط سواء من أولياء الأمور أو المعلمين لكي يتجاوزوا هذه المرحلة بسلام. 
تعرض طلاب الثانوية العامة لأخبار انتحار الطلاب علي مواقع التواصل الاجتماعي . حأب جدول (Y)

رأي المبحوثين في أي المناهج الدراسية التي تساعد في حل المشكلة

\begin{tabular}{|c|c|c|c|c|c|c|}
\hline \multirow{2}{*}{\multicolumn{2}{|c|}{ الإجمالي }} & \multicolumn{4}{|c|}{ العينة } & \multirow{3}{*}{ البدائل } \\
\hline & & \multicolumn{2}{|c|}{ ريف } & \multicolumn{2}{|c|}{ حضر } & \\
\hline المئوية & التكرار & $\%$ & ك & $\%$ & 5 & \\
\hline $70 . Y \varepsilon$ & YIE & $71 . Y T$ & 1.9 & $V \cdot \ldots$ & 1.0 & التربية الدينية \\
\hline ro.7. & $\Lambda \varepsilon$ & YY.\&. & $\varepsilon V$ & Yะ.7 & $\mu v$ & علم التفس \\
\hline 7.99 & $r \cdot$ & $V . \wedge 7$ & $1 \varepsilon$ & $\varepsilon . \cdots$ & 7 & علم الاجتماع \\
\hline$r . \varepsilon$ & 1 . & $\varepsilon . \leqslant 9$ & $\Lambda$ & 1.r & $r$ & اللغة العربية \\
\hline $1 \cdots$ & rrA & $1 \ldots$ & $1 \vee \wedge$ & $1 \ldots$ & 10. & الإجمالي \\
\hline
\end{tabular}

يتضـح من الجدول السـابق: أن (التربية الدينية) حازت علي الترتيب الأول بالنسبة

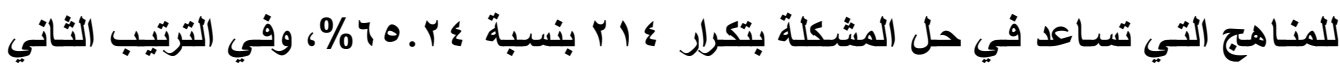

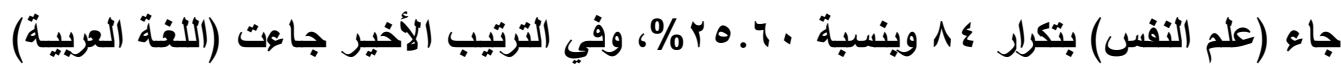

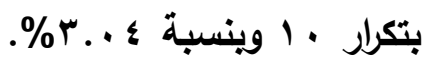
ويـري الباحث أن حصول (التربية الدينية) علي الترتيب الأول لمـا لها من ثقل بين المناهج من خلال النصوص القرآنية والأحاديث الشريفة والتي تحث علي حفاظ الإنسان علي حياته وتجرم الاتتحار (قتل التفس) بكل صوره، وتوضح عقاب من يقوم بهذه الجريمـة في حق نفسه.

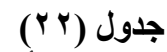

يوضح مقياس قلق الامتحان الناتج عن التعرض لأخبار انتحار الطلاب علي مواقع التواصل

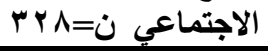

\begin{tabular}{|c|c|c|c|c|c|c|c|c|}
\hline \multicolumn{8}{|c|}{ العينة الكلية } & \\
\hline \multirow{2}{*}{ تيب } & \multirow{2}{*}{ المئوية } & \multirow{2}{*}{ 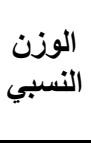 } & \multicolumn{5}{|c|}{ التكرار } & \\
\hline & & & معارض & ضعار & محاي & مواف & موافق & \\
\hline Yr &.$v 1 T$ & 118. & $\varepsilon \varepsilon$ & $r$ & 70 & $V \varepsilon$ & 110 & 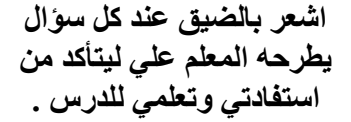 \\
\hline 17 &.$V Y_{1}$ & 1199 & rᄉ & rr & $7 \varepsilon$ & $1 \cdot r$ & $1 \cdot 1$ & سأرفع من صفالقلث حول ما إذا كنت الحالي إلى \\
\hline $1 \mathrm{~V}$ &. Vrq & 1197 & $\varepsilon$. & $\varepsilon r$ & $\varepsilon$. & $\vee \wedge$ & IYA & المعلم الوقوف بالتوتز إذا ما طلب مني القرة بصوت \\
\hline
\end{tabular}




\begin{tabular}{|c|c|c|c|c|c|c|c|c|}
\hline rr & $\because v$. & $11 \leqslant 1$ & $r \varepsilon$ & or & or & 97 & $9 \leq$ & 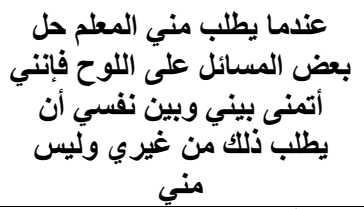 \\
\hline$\wedge$ & $\because \vee \wedge \wedge$ & Irqr & rq & $r$. & or & 71 & 109 & أثناء نومي احلم كثيرات \\
\hline 1 & $\because \wedge \vee$ & $1 \leqslant Y V$ & $\Lambda$ & $1 \varepsilon$ & rA & $\Lambda r$ & 190 & تزداد دقات قلبي عندما يقترب \\
\hline r & $\because \wedge \leq q$ & Irqr & Ir & Yr & $r$. & $V r$ & 191 & 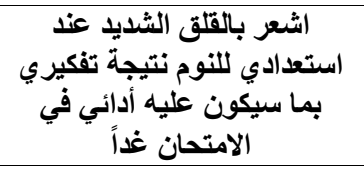 \\
\hline rV & $\because 7 \wedge 7$ & 1150 & $\varepsilon \varepsilon$ & $\varepsilon$ & v. & vq & 90 & عندمأ يطلب يدي التي اكتب التهلم الكتابة \\
\hline 1. & $\because \vee \vee 1$ & 1870 & Y & $r$. & 01 & Vq & $1 \leqslant Y$ & الامتحان بلائر عند أتثراب من موعد الطلاب \\
\hline Y & $\cdot .7 \wedge \vee$ & $11 \mathrm{rV}$ & $r \Lambda$ & $\mu \wedge$ & $\vee \wedge$ & 91 & $\Lambda \mu$ & 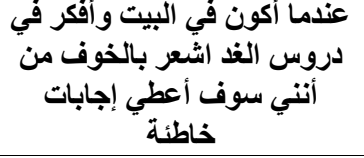 \\
\hline rV & $\because 7 \wedge \vee$ & 1174 & $\varepsilon \wedge$ & $\varepsilon \varepsilon$ & $0 \leqslant$ & Ar & $1 \ldots$ & 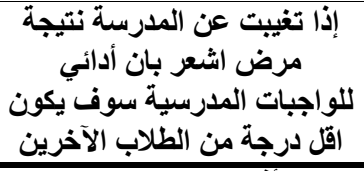 \\
\hline ro &. .791 & Ir & 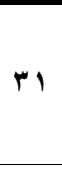 & $r \Lambda$ & $\Lambda r$ & 1.0 & VY & بعض اشما أفكر بلقروس بان أدائي في التالي \\
\hline rq & .719 & 1.10 & 71 & $7 \varepsilon$ & $\leq 0$ & vi & $\wedge$. & 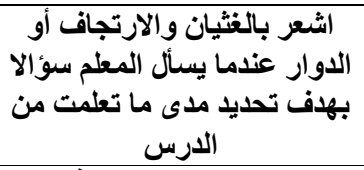 \\
\hline 14 & $\because v 01$ & IYTr & $r \varepsilon$ & $r \Lambda$ & VY & $\Lambda \varepsilon$ & Ir. & 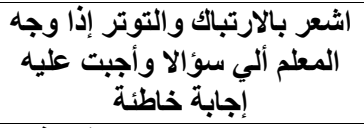 \\
\hline Ir & • & $1 Y 0 \leq$ & rA & $r$. & rד & $\Lambda \wedge$ & $1 \% 9$ & اشعر بخوف من كل موقف فيه \\
\hline$v$ & $\because \wedge$. & IrIr & 17 & rı & OV & 79 & 171 & اشعر بضيق شديد قبل دخولي \\
\hline 11 & .874 & Irov & $r \cdot$ & $r \varepsilon$ & o. & 1.1 & IrT & بالتوتر حول أدائي في هذاء الامتحان اشعر \\
\hline 19 & $\because V Y r$ & 1110 & rr & $r \wedge$ & $V \varepsilon$ & 90 & 99 & 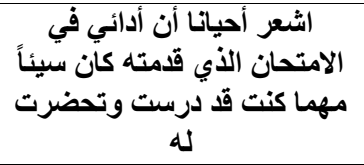 \\
\hline
\end{tabular}




\begin{tabular}{|c|c|c|c|c|c|c|c|c|}
\hline 10 & $\because \vee \mu \wedge$ & $|r|$. & rq & rr & $\leqslant 7$ & 1 & Iro & أثناء الامتحان ترتجي إنت بعض بها \\
\hline 9 & $\because V \vee \leq$ & Irv. & $r$. & $r \varepsilon$ & 4 & $9 \varepsilon$ & IYA & 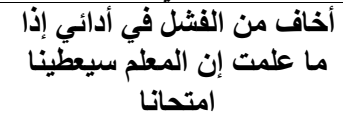 \\
\hline$\varepsilon$ & • & rדו & $1 \varepsilon$ & 17 & $\leqslant \wedge$ & VV & IVT & كثيرا من ألمعلومـات أنسئ التي كنت الامتحان \\
\hline 0 & $\because$ Aro & Iror & 17 & $1 \varepsilon$ & o. & $\wedge 1$ & 178 & 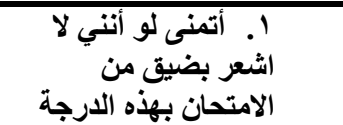 \\
\hline $1 \varepsilon$ & $\because v \leq q$ & Irrq & rr & & Tr & १V & 114 & 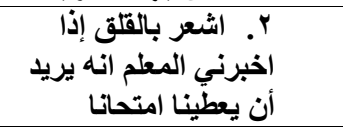 \\
\hline$r \varepsilon$ & .791 & E & $\varepsilon$ & rq & $7 \varepsilon$ & 1.1 & $\Lambda \varepsilon$ & 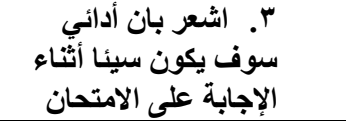 \\
\hline r1 & $\because V / 0$ & IIVY & $r$. & $r v$ & VY & 94 & 97 & 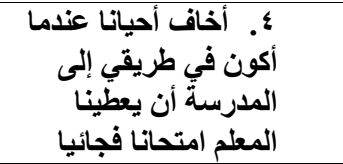 \\
\hline 11 & $. V Y \leq$ & $11 \wedge V$ & $\varepsilon r$ & $\leqslant r$ & $\leqslant 0$ & 79 & ir. & قبل وأثناء الامتحاع شدان \\
\hline r. & $\cdot V r$ & 1111 & $\varepsilon r$ & rA & 09 & $\wedge 9$ & 11. & 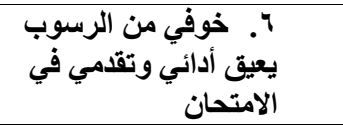 \\
\hline$r$ & ه • & 11599 & 1. & 11 & $\leqslant \wedge$ & $\wedge 1$ & $|v|$ & 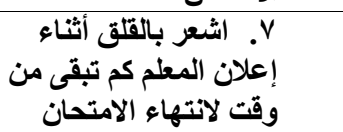 \\
\hline 7 & $\cdot \Lambda \cdot \varepsilon$ & 1419 & $\wedge$ & rr & TV & $\wedge q$ & $1 \leqslant r$ & 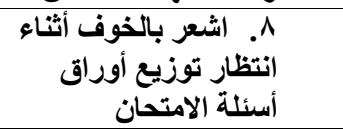 \\
\hline
\end{tabular}

يتضح من الجدول السابق أن: النسب المئوية لمقياس قلى الامتحان تراوحت ما بين

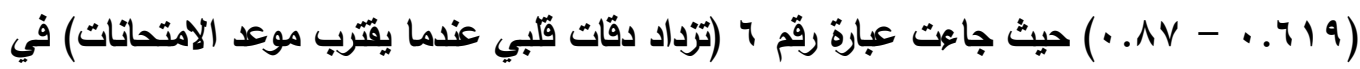
الترتيب الأول، وحازت عبارة رقم V (اشعر بالقلق الثديد عند استعدادي للنوم نتيجة تفكيري بما

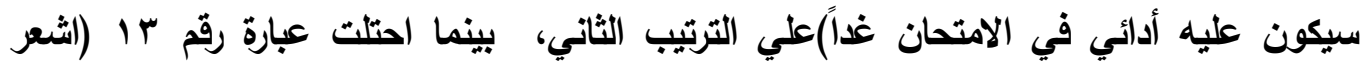
بالغثيان والارتجاف أو الدوار عندما يسأل المعلم سؤلا بهدف تحليد مدى ما تعلمت من الدرس) في

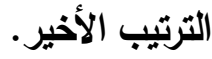
ويري الباحث أن حصول العبارة (تزداد دقات قثلبي عندما يقترب موعد الامتحانات) علي الترتيب الأول والعبارة (اشعر بالقلق الثديد عند استعدادي للنوم نتيجة تفكيري بما سيكون عليه أدائي 
في الامتحان غداً) علي الترتيب الثاني تؤكد علي مدي القلث الثديد الأي يتعرض لها الطلاب من الامتحان جراء تعرضهم لأخبار الاتتحار علي مواقع التواصل الاجتماعي.

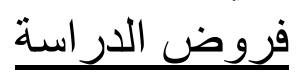

ا - لا توجد فروق ذات دلالة إحصائية بين عينة الدراسة من حيث المتغيرات الايموجرافية (النوع (ذكور - إناث) - محل الإقامة (حضر - ريف) في معدل التعرض لأخبار انتحار الطلاب علي مواقع التواصل الاجتماعي.

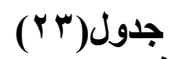

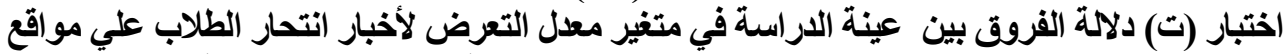

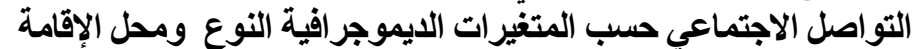

\begin{tabular}{|c|c|c|c|c|c|c|c|}
\hline الدلاكة & مستوى الدلاية & الحرجية & قيمة ت & المعياري & الحستبي & المجموعة & المتغيرات \\
\hline \multirow{2}{*}{ غير داليا } & \multirow{2}{*}{$\because A \cdot 9$} & \multirow{2}{*}{ एवq } & \multirow{2}{*}{$\cdot r \leqslant r$} & $\cdot r q \leq$ & $\cdot . \wedge 1$ & ذكر=q & \multirow{2}{*}{ لأخبار التتحار } \\
\hline & & & & $\cdot . \varepsilon \cdot r$ & $\cdot . \wedge$ & أنثى=99 1 1 & \\
\hline \multirow{2}{*}{ غير داليا } & \multirow[b]{2}{*}{ ד } & \multirow[b]{2}{*}{ ए99 } & \multirow[b]{2}{*}{$\cdot \vee \wedge \wedge$} & $\cdot . \mu \Lambda$ &..$\wedge r$ & حضر =9 & \multirow{2}{*}{ الإجتماصل } \\
\hline & & & & $\cdot . \leqslant 1$ & $\because \vee 9$ & ريف=9 | & \\
\hline
\end{tabular}

أظهرت نتائج الجدول السابق: تحقق الفرض وهو عدم وجود فروق ذات دلالة إحصائية بين عينة الدراسة حسب (النوع (ذكور - إناث) - ومحل الإقامة (حضر - ريف) في معدل التعرض لأخبار انتحار الطلاب على مواقع التواصل الاجتماعي. ويرى الباحث أن تحقق الفرض بعدم وجود فروق في معدل التعرض لأن الريف في الآونة الأخيرة لبس لباس التحضر والمدنية في معظم مظاهر الحياة، وأيضا ــعام وجود فروق في النوع لأن الإناث لا توجد عليها قيود في عملية التعليم ولا في استخدام مواقع مئع التواصل الاجتماعي. r - - توجد علاقة ذات دلالة إحصائية بين درجة تعرض الطلاب عينة الدراسة لأخبار الانتحار علي مواقع التواصل الاجتماعي ودرجة الثقة في ما تعرضه من أخبار. 
تعرض طلاب الثانوية العامة لأخبار انتحار الطلاب علي مواقع التواصل الاجتماعي...

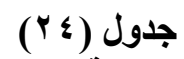

معامل الارتباط بين درجة تعرض الطلاب عينة الاراسة لأخبار الاتتحار علي مواقع التواصل

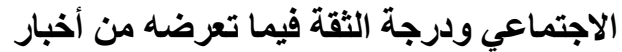

\begin{tabular}{|c|c|c|c|c|c|}
\hline \multirow[t]{2}{*}{ الالاكة } & \multirow[t]{2}{*}{ نوع الدلالة } & \multirow[t]{2}{*}{ مستوي الدلاية } & \multirow[t]{2}{*}{ الحرية } & الثقة في ما تعبرض & \multirow[t]{2}{*}{ المتغيرات } \\
\hline & & & & معامل الارتباط & \\
\hline طردي & احصائيا & $\because \cdots$ & 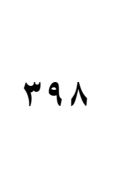 & $\because 11 \leq$ & الار معدل تعزرض الأخبار الانتحاب \\
\hline
\end{tabular}

أظهرت نتائج الجدول السابق: تحقق الفرض بوجود ارتباط ذذات دلالة إحصائية بين

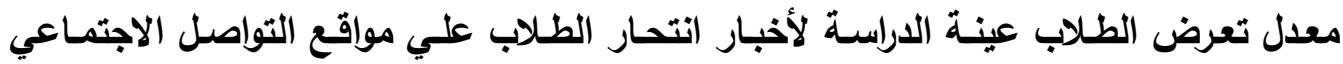

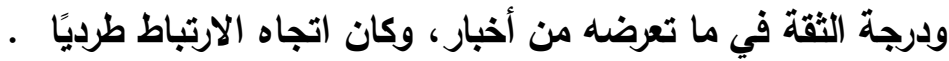
r- لا توجد فروق ذات دلالة إحصائية بين عينة الدراسة حسب محل الإقامة (حضر - ريف) في درجة الثقة في الأخبار التي تعرضها مواقع التواصل الاجتماعي.

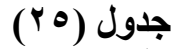

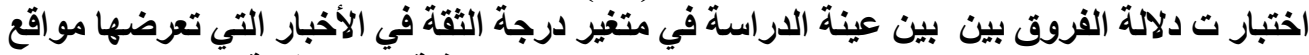
التواصل الاجتماعي حسب المتغير ات الايموجر افية محل الإقامة الإنة

\begin{tabular}{|c|c|c|c|c|c|c|c|}
\hline الدلالة & الدلالية & الحرية & قيمة ت & المعياري & الحسابي & المجموعة & المتغيرات \\
\hline \multirow[b]{2}{*}{ غير دال } & \multirow[b]{2}{*}{$\because 90$} & \multirow[b]{2}{*}{ एव } & \multirow[b]{2}{*}{$1.7 V r$} & r.11 & 1.11 & حضر= IV9 & \multirow{2}{*}{ تالأخبار التئي } \\
\hline & & & & $1 . \wedge 1$ & $\vee . \vee \wedge$ & ريف=9 | & \\
\hline
\end{tabular}

أظهرت نتـائج الجدول السـابق: تحقق الفرض وهـو عدم وجـود فـروق ذات دلالـة إحصائية بين عينة الدراسة حسب محل الإقامة (حضر - ريف) في درجة الثقة في الأخبار التي تعرضها مواقع التواصل الاجتماعي. 
ع - توجد فروق ذات دلالة إحصائية بين عينة الاراسة حسب محل النوع (ذكور - إناث) في درجة الثقة في الأخبار التي تعرضها مواقع التواصل الاجتماعي لصالح الأكور.

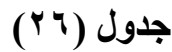

اختبار ت دلالة الفروق بين عينة الدراسة في متثير معدل التعرض درجة الثقاعة في الأخبار التي تعرضها مواقع التواصل الاجتماعي حسب المتغيرات الليموجرافية النوع فئي

\begin{tabular}{|c|c|c|c|c|c|c|c|}
\hline نوع الدلالة & الدلالة & الحرجية & قيمة ت & المعياري & الحستوسط & المجموعة & المتغيرات \\
\hline \multirow[b]{2}{*}{ دال احصائيا } & \multirow[b]{2}{*}{$\because \cdots$} & \multirow[b]{2}{*}{ एवq } & \multirow[b]{2}{*}{$0 . r \leqslant V$} & 1.87 & $V . \leqslant \leqslant$ & ذكر=q & \multirow{2}{*}{ 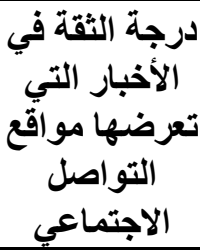 } \\
\hline & & & & r.1. & 1. $\leqslant 4$ & أنثى=9 1 ا & \\
\hline
\end{tabular}

أظهرت نتـائج الجدول السـابق: عدم تحقق الفرض بعدم وجـود فروق ذات دلالـة

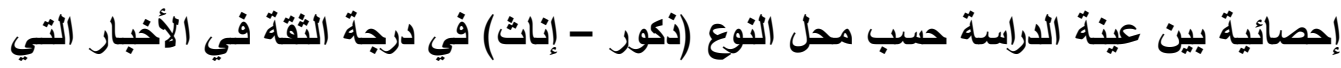
تعرضها مواقع التواصل الاجتماعي في اتجاه الإناث ذوي المتوسط الأكبر.

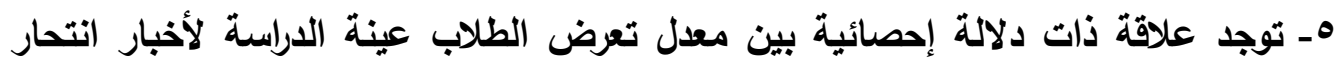
الطلاب علي مواقع التواصل الاجتماعي ودرجة قلق الامتحان.

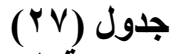

معامل الارتباط بين معدل تعرض الطلاب عينة الاراسة لأخبار انتحار الطلاب علي مواقع الأع الأحئ التو اصل الاجتماعي ودرجة قلق الامتحان الإني

\begin{tabular}{|c|c|c|c|c|c|}
\hline الاتجاه & الدالاعة & الدلالة & الحرجية & معامل الارتباط & المتغيرات \\
\hline طردي & احصائيا & $\because \cdots$ & ras & צ • & 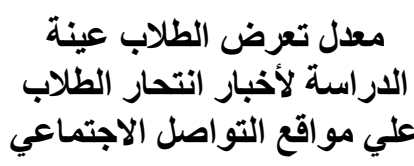 \\
\hline
\end{tabular}

أظهرت نتائج الجدول السابق: تحقق الفرض ووجود ارتباط ذات دلالة إحصائية بين

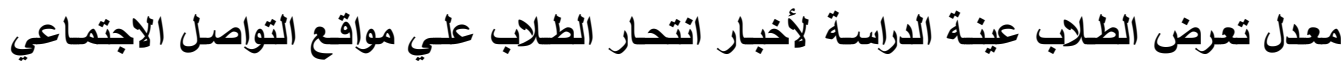
ودرجة قلق الامتحان، وكان اتجاه الارتباط طرديًا. 
צ-لا توجد فروق ذات دلالة إحصائية بين عينة الدراسة حسب المتغيرات الديموجرافية (النوع (ذكور - إناث") - محل الإقامة (حضر - ريف) في قلى الامتحان الناتج عن التعرض لأخبار

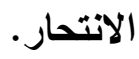

$$
\text { جدول (r^) }
$$

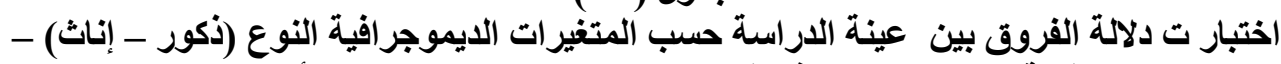

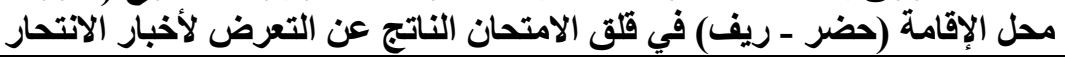

\begin{tabular}{|c|c|c|c|c|c|c|c|}
\hline الدلالة & مستوى الدلالة & الحرية & قيمة ت & الانحراف المعياري & الحستوسطي & المجموعة & المتغيرات \\
\hline \multirow{2}{*}{ احصائيا } & \multirow{2}{*}{$\because \cdots$} & \multirow{2}{*}{ raA } & \multirow{2}{*}{$\varepsilon .\left\{Y_{1}\right.$} & \&1.99 & $79.0 \mathrm{~V}$ & ذكر=9 · + & \multirow{4}{*}{ 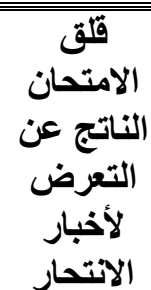 } \\
\hline & & & & $\leq \wedge . \wedge \leq$ & 99.70 & أنثى=9 1 | & \\
\hline \multirow{2}{*}{ غير دال } & \multirow[b]{2}{*}{$.0 r$} & \multirow[b]{2}{*}{ rqA } & \multirow[b]{2}{*}{.70} & $\varepsilon V_{.1}$ & $9 \cdot . V V$ & حضر=111 & \\
\hline & & & & $\leqslant 0.9$. & AV.Vr & ريف=9 | ب & \\
\hline
\end{tabular}

أظهرث نتائج الجدول السابث: تحقق الفرض بعدم وجود فروق ذات دلالة إحصائية بين عينة الاراسة حسب محل الإقامة (حضر - ريف) في متغير قلق الامتحان الناتج عن

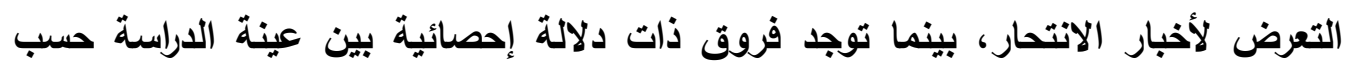
النوع (ذكور - إناث) في متغير قلق الامتحان الناتج عن التعرض لأخبار الانتحار في اتجاه الاناث ذوي المتوسط الأكبر.

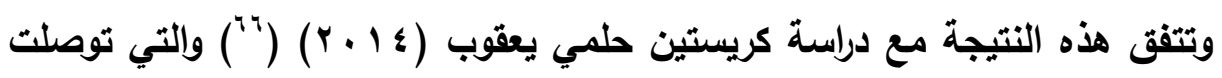
إلي لا توجد فوق ذات دلالة إحصائية بين متوسط درجات كل من الأكور والإناث فى مستوى

$$
\text { ملقى الامتحان. }
$$

بالنسبة لمتابعة أفراد العينة لمواقع التواصل الاجتمـاعي حسب منطقة السكن للحضر والريف وحسب النوع بالنسبة للذكور والإناث تصدرث (دائماً) الترتيب في الترتيب الأول

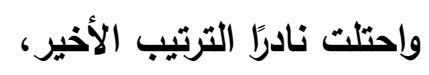

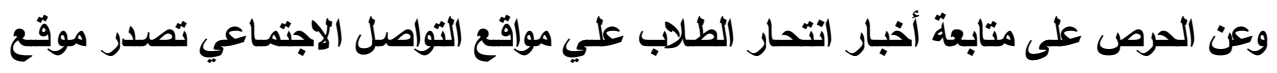
(يوتيوب) مواقع التواصل الاجتمـاعي التي يحرص المبحوثُون على متابعة الأخبار فيما

$$
\text { حل موقع( توتير) في الترتيب الأخير. }
$$




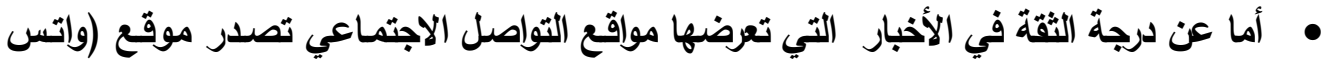

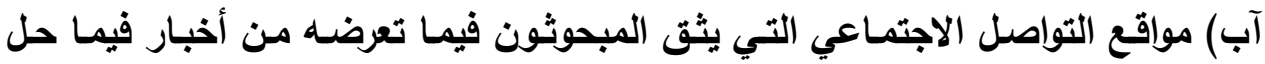

$$
\text { موقع (توتير) في الترتيب الأخير. }
$$

وعن التعرض لأخبار الانتحار حسب نوع العينة (ذكور - اناث) جاء تعرض الأكور لأخبار الانتحار في الترتيب الأول والذين لا يتعرضون في الترتيب الثاني، وأيضاً بالنسبة التانية للإناث نفس الترتيب، ويالنسبة لمنطقة السكن (حضر - ريف) طلاب الحضر الذين يتعرضون لأخبار الانتحار في الترتيب الأول، والذين لا يتعرضون في الترتيب الثاني، وأيضاً بالنسبة لطلاب الريف نفس الترتيب. وعن الصورة التي يكونها أفراد العينـة للطالب المنتحر تصدرت (لع يجد من يدعمـه

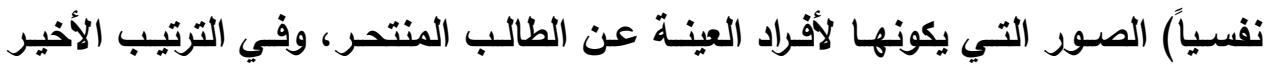
(ساعد في تثويه صورة الطالب اجتماعيًا ودينيًا)

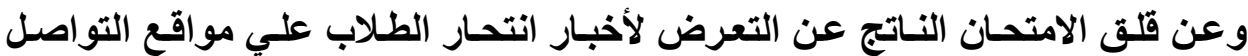

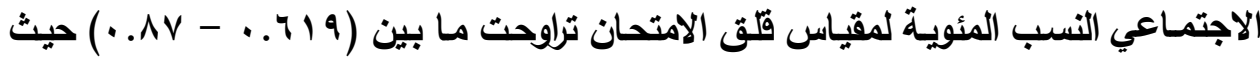
جاءت عبارة رقم \ (تزداد دقات قلبي عندما يقترب موعد الامتحانات) في الترتيب الأول، بينما

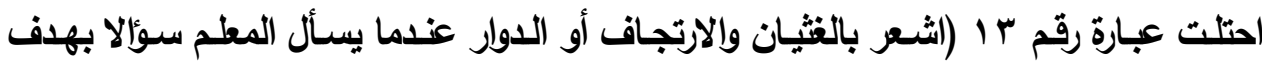
تحليد مدى ما تطلت من الدرس) الترتيب الأخير. تحقق الفرض الأول من خلال عدم وجود فروق ذات دلالة إحصائية بين عينة الدراسة حسب (النوع (ذكور - إناث) - محل الإقامة (حضر - ريف) في معدل التعرض لأخبار انتحار الطلاب علي مواقع التواصل الاجتماعي. وتحقق الفرض الثاني بوجود ارتباط ذات دلالة إحصائية بين معدل تعرض الطلاب عينة الطاعي

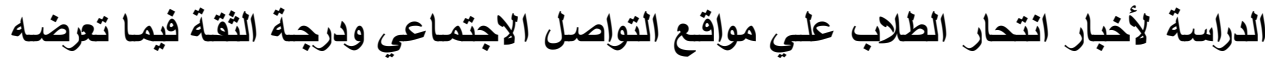

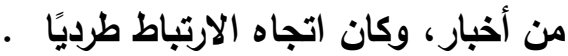
وتحقق أيضاً الفرض الثالث بعدم وجود فروق ذات دلانيات إحصائية بين عينة الدراسـة حسب محل الإقامة (حضر - ريف) في درجة الثقة في الأخبار التي تعرضها مواقع دالئ

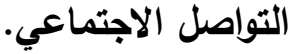


• كما أظهرت النتائج عدم تحقق الفرض الرابع بعدم وجود فروق ذات دلالة إحصائية بين

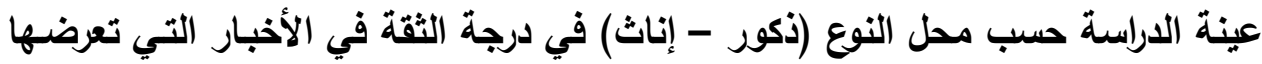
مواقع التواصل الاجتماعي في اتجاه الإناث ذوي المتوسط الأكبر. وتحقق الفرض الخـامس بوجود ارتباط ذات دلالة إحصائية بين معدل تعرض الطلاب

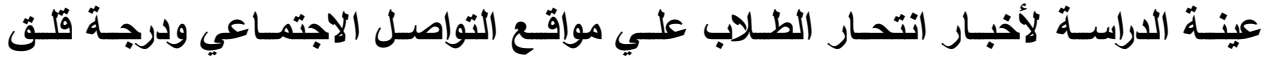
الامتحان، وكان اتجاه الارتباط طرديًا. وتحقق الفرض السادس بعدم وجود فروق ذات دلالة إحصائية بين عينة الدراسة حسب محل الإقامة (حضر - ريف) في متغير قلق الامتحان الناتج عن التعرض لأخبار الانتحار، بينما توجد فروق ذات دلالة إحصائية بين عينة الدراسة حسب النوع (ذكور إناث) في متغير قلى الامتحان الناتج عن التعرض لأخبار الانتحار في اتجاه الإناث ذوي المتوسط الأكبر - المبر

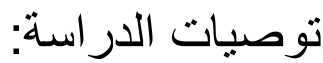
1 - إخضاع مواقع التواصل الاجتماعي لمزيد من الدراسات المتعقة والتحليلية والميدانية للاستفادة منها بشكل ايجابي لحل هذه المشكلة . r- حث وتثجيع علماء النفس بإنشاء حسابات لهم علي شبكات التواصل الاجتماعي للتواصل مع الطلاب بشكل مستمر ودعمهم نفسياً لئلا في الخضوع لهذه المحاولات. r- ضرورة تعيين خبراء من علماء الإعلام والنفس والاجتماع والتربية علي شكل لجان مشتركة لمراقبة مواقع التواصل الاجتماعي ومتابعة معالجتها لأخبار الانتحار والرد علي المبالغات في عرض هذه الأخبار . ع - لا بد من وضع قوانين رادعة وملزمة تنظم عملية نشر هذه الأخبار والفيديوهات التي تتسبب في الإيذاء للطلاب وإحباطهم معنوياً ونفسياً، ه- عمل دورات وورش للطلاب في المدارس يديرها علماء الدين والصحة النفسية والاجتماع والتربية لاعم الطلاب وإعادة بناء الأات لايهم. צ- عمل حملات توعية علي مواقع التواصل لتوعية أولياء الأمور بكيفية دعم أبنائهم 
تعرض طلاب الثانوية العامة لأخبار انتحار الطلاب علي مواقع التواصل الاجتماعي . تلمان.

ما تثيره الدر اسة من بحوث مستقبلية:

• • أجراء دراسة حول معالجة الصحف لقضية انتحار طلاب الثانوية العامة.

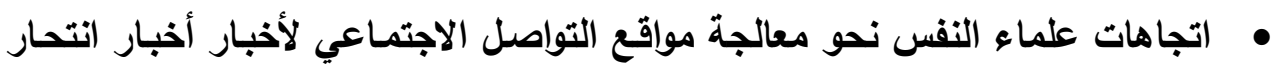

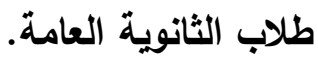

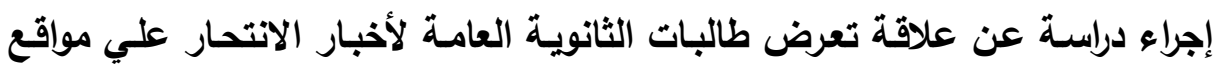

التواصل وعلاقته بقلق المستقبل لايهم.

اتجاهات أولياء الأمور نحو معالجة مواقع التواصل الاجتماعي لأخبار انتحار طلاب التابل

الثانوية العامة، وعلاقته بمستوي الاعم النفسي للأبناء. 


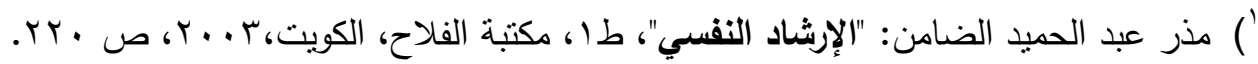

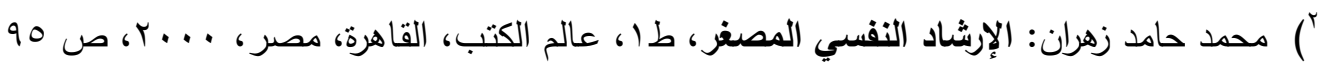

3 ) Ronny T. WIRASTO:" Suicide Prevention in Indonesia: Providing public advocacy", a presentation made at the Symposium "Indonesian Medical Association, Jakarta, Indonesia, JMAJ, January, Vol 55, No 1, February 2012

๕) صحيفة اليوم السابع: أرقام صادمة عن الانتحار حول العالم .. أوروبا فى المقدمة والثرق الأوسط

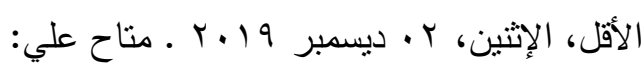
https://www.youm7.com/story/2019/12/2

•) Available on: https://ourworldindata.org/suicide , 17/1/2020

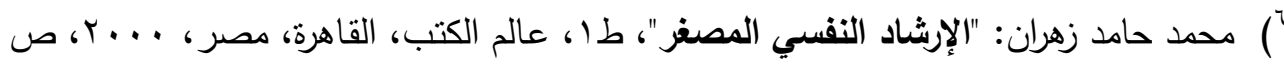

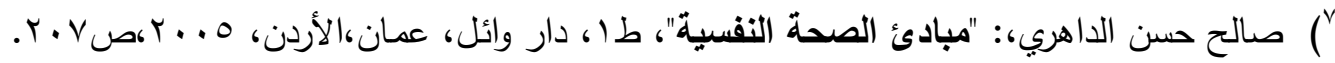

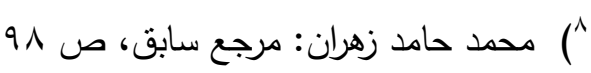

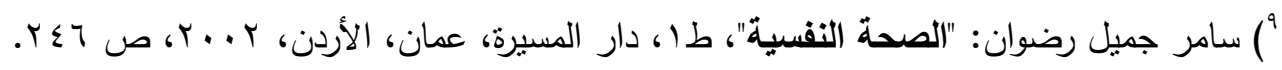

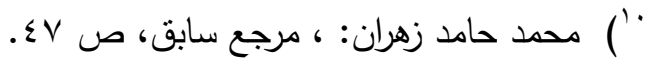

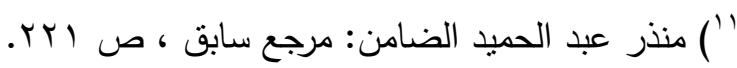

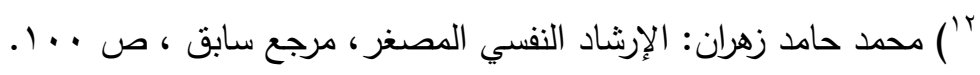

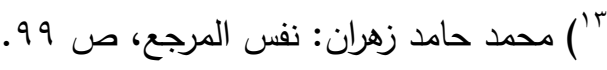

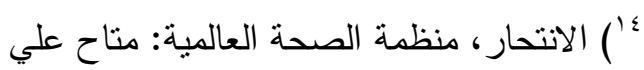
https://www.who.int/ar/news-room/fact-sheets/detail/suicide º') سوسن شاكر مجيد:" اضطرابات الثخصية أنماطها قياسها"، عمان، دار الصفاء للنشر والتوزيع،

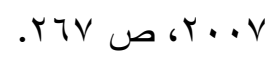

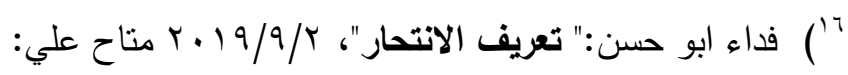

https://mawdoo3.com

${ }^{17}$ ) Surachai Chaniang and others:" Perceptions of Adolescents, Teachers and Parents towards Causes and Prevention of Suicide in Secondary School Students in Chiang Mai, Journal of Nursing Research, Vol 23 No 1, 2019, January-March 2019 


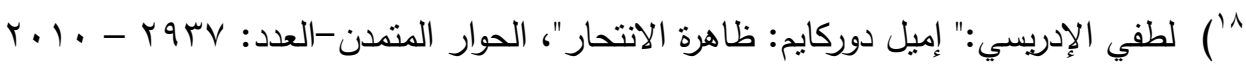

$$
\text { ( · 19/9/\%) }
$$

http://www.ahewar.org

19) Mahmoud Eid and Stephen J. A. Ward, Ethics, New Media, and Social Networks, Global Media Journal , Canadian Edition, Volume 2, Issue 1, pp. 1-4,2009,

${ }^{20}$ ) Hawker, Mark. D, Developer's Guide to Social Programming: Building Social Context Using Face book, Google Friend Connect, and the Twitter API, Canada: Addison-Wesley Professional; 1 edition, August 25, , 2010 1) محمود الفطاطنة ، "علاقة الإعلام الجديد بحرية الرأي والتعبير في فلسطين " ، فلسطين ، المركز

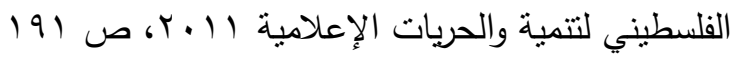

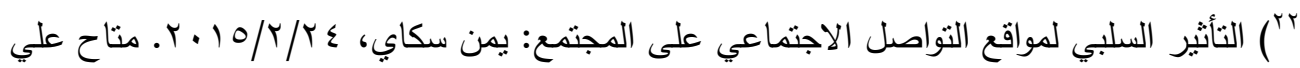
https://www.yemensky.com/news1270.html

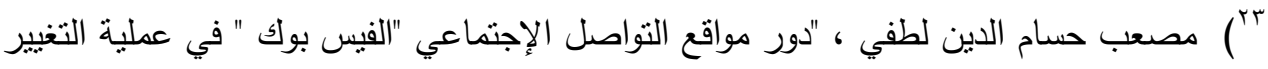

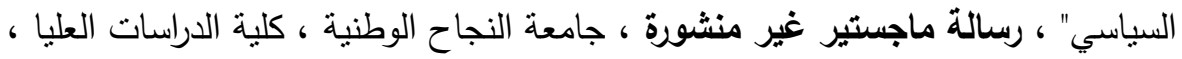
. 9 T מ

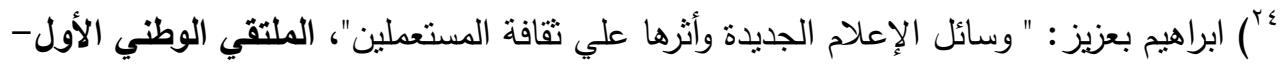

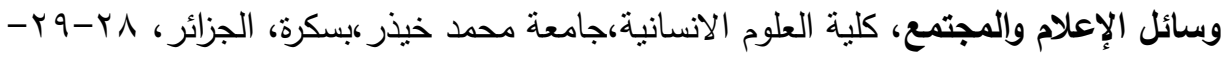

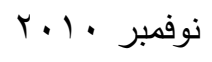

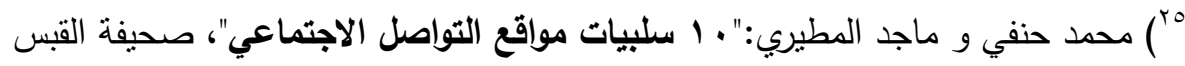

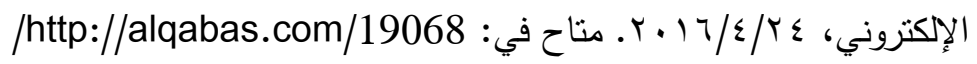

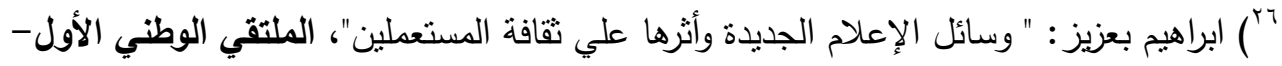
وسائل الإعلام والمجتمع،مرجع سابق.

27 ) Sefa Bulut Yunus Altundag:" The Effect of Solution-Focused Brief Counseling on Reducing Test Anxiety", January 2019, Available on: https://www.researchgate.net

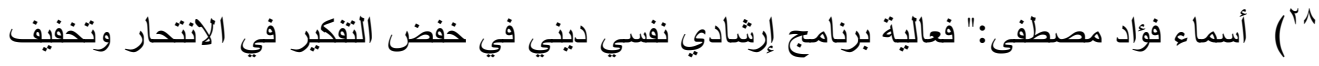
العوامل المرتبطة به لدي طلاب الجامعة"، رسالة ماجستير غير منشورة، جامعة طنطا، كلية

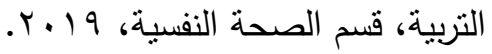




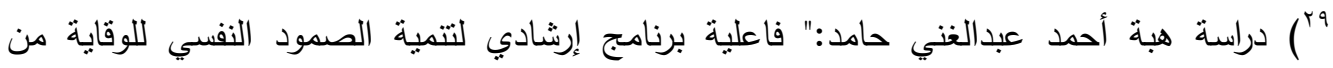

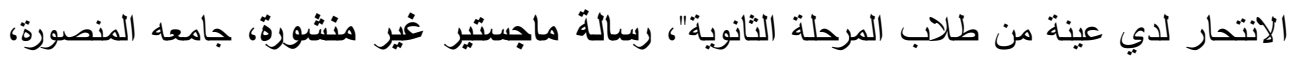

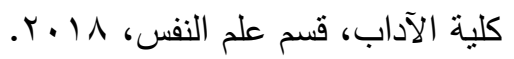

30 ) Junrong She , Yong Li:" Bullying and suicide in high school students: Findings from the 2015 California youth risk behavior survey", Journal of Human Behavior in the Social Environment, USA, Volume 28, 2018 Issue 6

"r) ميادة محمد عبد الله القعود:" الميول الانتحارية والمساندة الاجتماعية لاى عينة من المتحولين

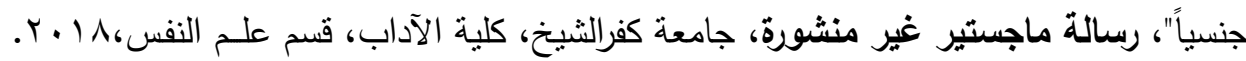

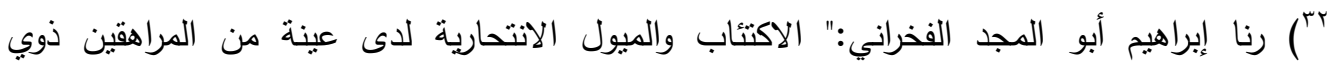

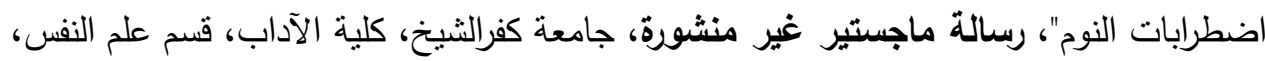
.$r \cdot 11$

$\left.{ }^{33}\right)$ Saravia, Janet. How are social media sites affecting the social and emotional development of youth?., Degree Level masters , Department of Social Work, California State University - Northridge,2017 .

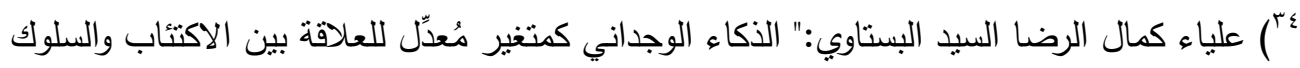

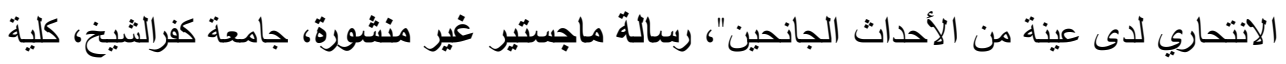

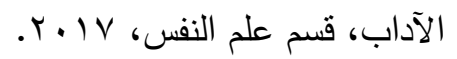

${ }^{35}$ ) Dennis, James William. It's better to light a candle than to fantasize about a sun : social media,political participation and slacktivism in Britain, PhD Degree doctoral, Royal Holloway, University of London,2016 بَ") أسماء عثماني بن سعدون:" قلق الامتحان واستراتيجيات المواجهة عند طلاب البكالوريا"، مجلة

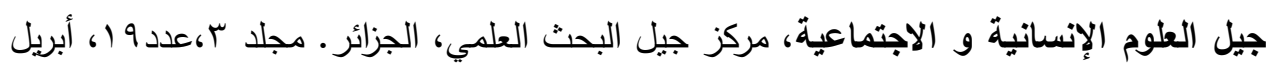

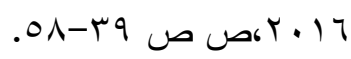

${ }^{37}$ ) Amanda Lenhart, "Teens, Social media and technology Overview “Available on ,https://www.scribd.com/document/261389225/PewResearch-Center-Teens-Social-Media-and-Technology-Overview-2015 . ^^") ريم بندر السلمان:" صور الانتحار لدى عينة من المراهقين: دراسة ارتباطية"، كلية الدراسات

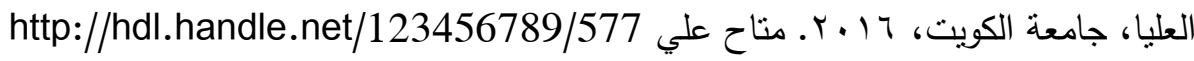

39) Tadele Amare and others:"Prevalence and Associated Factors of Suicide Ideation and Attempt among Adolescent High School Students in Dangila 
Town, Northwest Ethiopia", Psychiatry Journal, Volume 2018, Article ID 7631453, 9 pages, avalable at https://doi.org/10.1155/2018/7631453

${ }^{40}$ ) Ellison, Nicole B.; Vitak, Jessica; Gray, Rebecca; Lampe, Cliff. ,2014, Cultivating Social Resources on Social Network Sites: Facebook Relationship Maintenance Behaviors and Their Role in Social Capital Processes,.Journal of Computer-Mediated Communication. Jul2014, Vol. 19 Issue 4, pp.855-870 .

41 ) Hilda N Shilubane and others:" High school students' knowledge and experience with a peer who committed or attempted suicide: a focus group study", BMC Public Health, Article number: 1081, 2014 , avalable on https://bmcpublichealth.biomedcentral.com

${ }^{42}$ ) 14) Rebecca Luebbert, Ann Popkess:"The Influence of Teaching Method on Performance of Suicide Assessment in Baccalaureate Nursing Students", The Journal of the American Psychiatric Nurses Association, USA, First Published May 14, 2015, avalable on https://doi.org

rأسامة محمد عبد الرحمن:" دور الصفحات الإخبارية بالفيس بوك في إمداد الثباب الجامعي

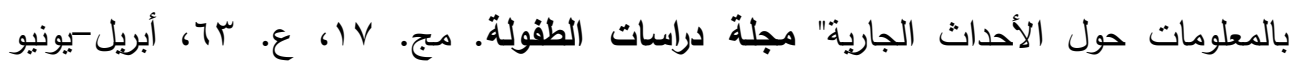

$$
\text { . }
$$

צ؛) كريستين حلمي يعقوب حنا:" أثز التغذية الراجعة الحيوية في خفض قلق الامتحان لدى عينة من هن طلاب وطالبات الجامعة"، رسالة ماجستير غير منشورة، جامعة عين شمس. كلية التربية، قسم الصحة النفسية والأرشاد النفسى.

${ }^{45}$ ) .15) Parra UribeacH.Blasco-Fontecilla:" Attempted and completed suicide: Not what we expected",Journal of Affective Disorders, USA, Volume 150, Issue 3, 25 September 2013, Pages 840-846

${ }^{46}$ ) Kim, Yun-Hee and others:" A Study on a Relationship Between University Students Life Stress and SuicidalIdeation:MediatingEffct of Mental Health", Journal of Digital Convergence, Corea scince, Corea, Volume 13 Issue 11 / Pages.291-301..

47 ) Park, Dae-Sung:" Effects of Life Stress and Depression of Health College Students on Their Suicidal Ideation : Control Effects of Social Support", Journal of the Korea Academia-Industrial cooperation Society, Korea 9 Volume 14 Issue 2 / Pages.728-736 / 2013

^^) دراسة سليمة سايحي:" الكثف عن بعض خصائص خط اليد لدى التلاميذ ذوي مستوى قلق

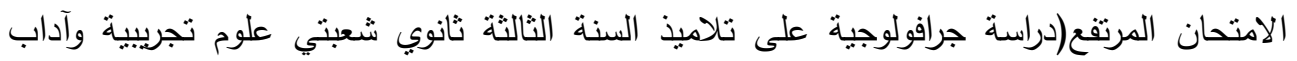

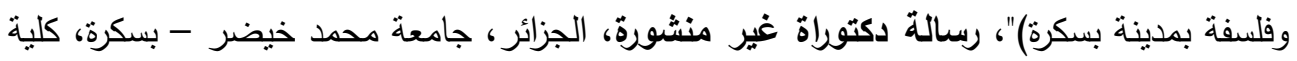

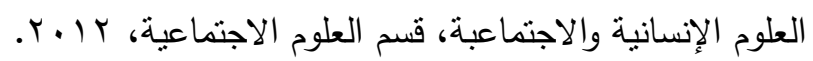


${ }^{49}$ ) Sullinan,S\& Paradise, (IN) visimle threats? The third - person effect in perceptions of the influence of Fecebook, Cyber psychology, Behavior, and social Networking, 15 (1) pp 55-61, 2012, Available on https://www.ncbi.nlm.nih.gov/pubmed/21988734

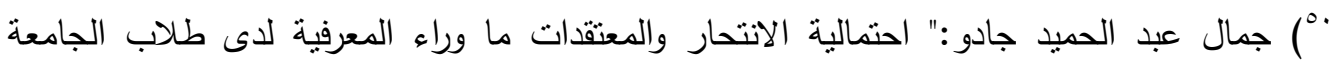

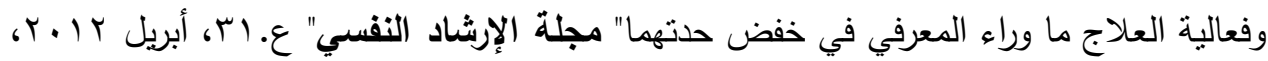

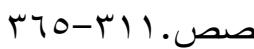

10) جمال السيد تفاحة:" السلوك الانتحارى: دراسة تتخيصية علاجية، "مجلة كلية التربية"، جامعة

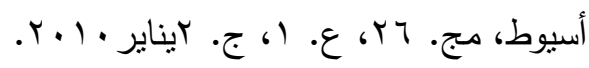

${ }^{52}$ ) Baumgartner ,Morris ,"The Effects of Digital Media on Political Knowledge and Participation in Election Campaigns: vidence From Panel Data", Unpublished .M.A, M.A, MidSweden University, ,Sundsvall, ,Sweden.2010. Available on http://crx.sagepub.com/content/early/2011 ror ميادة عثمان حسن محمد: قلق الامتحان و علاقته بالتحصيل الأكاديمي لاى طلاب جامعة

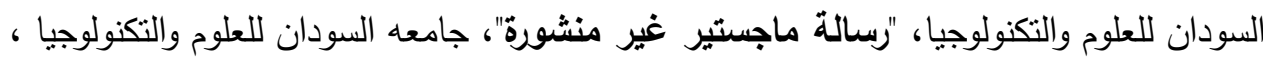

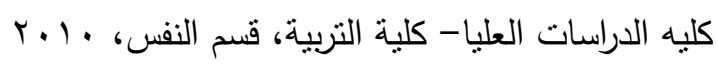

${ }^{54}$ ) Hall .A, College students motives for using social network sites and their relationshps to users .personality traits, Conference Papers international communication association, Annual Meeting, p 1-38, 2010

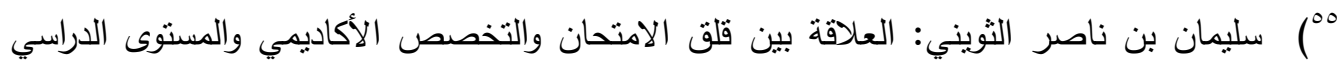

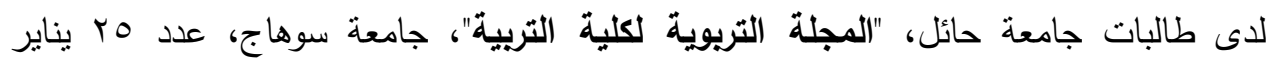

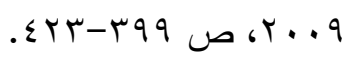

${ }^{56}$ ) HyunsanCho:" Early initiation of substance use and subsequent risk factors related to suicide among urban high school students", Addictive Behaviors, USA, Volume 32, Issue 8, August 2007, Pages 1628-1639 vo ملامة الثارف سالم خليفة:" مستويات قلق الامتحان وعلاقتها باضطرابات النوم لدى طلاب

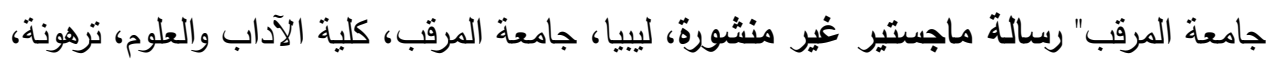

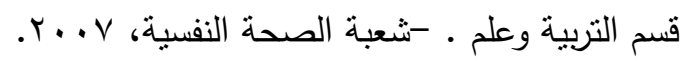

ox) Brian NyatangaHilde de Vocht:" Towards a definition of death anxiety", .International Journal of Palliative Nursing, Vol. 12, No. 9, pp 410-413,2006 ${ }^{\circ 9}$ ) Takahashi \& Newmen:" Test Anxiety and Academic Performance in Undergraduate and Graduate Students", Journal of Educational Psychology, Vol 97No(2), 2005,pp 268-274 
•) عبير محمد شعبان:" مخاطرة الانتحار وعلاقتها بسمات الثخصية واحداث الضاغطة"، رسالة

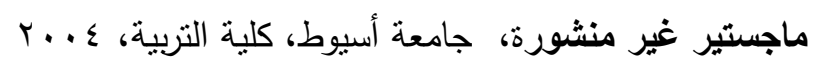

(7) Sullivan:" The effect of test anxiety on attention and memory skills in undergraduate students of Charleston, Research journal at the college

, Vol 1. pp $263-273,2002$

$\left.{ }^{\top}\right)$ Jerrell C. Cassady:" Cognitive Test Anxiety and Academic Performance", Contemporary Educational Psychology, 27(2):270-295 • April 2001. Available at: https://www.researchgate.net/publication

${ }^{\top}$ ) Hall .A, College students motives for using social network sites and their relationshps to users .personality traits , 2009, Op.Cit

İ) Amanda Lenhart, "Teens, Social media and technology Overview, 2015, Op.Cit

$$
\begin{aligned}
& \text { "7o أسامة محمد عبد الرحمن:" دور الصفحات الإخبارية بالفيس بوك في إمداد الثباب الجامعي }
\end{aligned}
$$

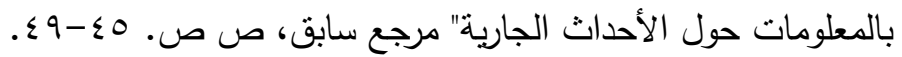

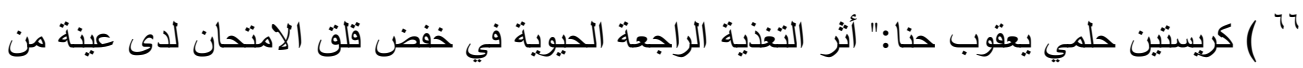

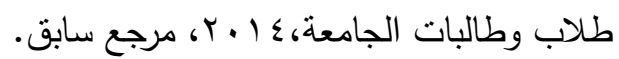

